\title{
O MEDICAMENTO HOMEOPÁTICO NOS SERVIÇOS DE SAÚDE
}

\section{AMARILYS DE TOLEDO CESAR}

Tese de Doutorado apresentada ao Departamento de Práticas de Saúde Pública da Faculdade de Saúde Pública da Universidade de São Paulo para obtenção do Grau de Doutor.

Área de concentração: Práticas de Saúde Pública.

ORIENTADORA: PROF. DR. EVELIN NAKED DE CASTRO SÁ

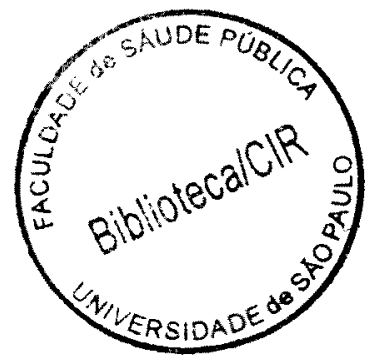




\section{DEDICATÓRIA:}

Ao Xico, Gabriel, Lauro e Natália, com amor.

A meus pais.

À Hahnemann, e aos homeopatas que fazem da Homeopatia sua missão. 


\section{AGRADECIMENTOS:}

Ao Xico, pelo apoio, pelas idéias, pelas discussões, pelo incentivo, pelo amor.

À minha mãe, por todas as vezes em que cuidou de meus filhotes.

À orientação segura e tranqüila da Dra. Evelin.

À Beth, pelo apoio e idéias. A ela e a todos que me substituiram enquanto eu trabalhava neste outro projeto.

Ao Marcelo e à Mara de Florianópolis; ao Ubiratan da IAKAP; à Claudia, de Brumadinho; à Claudia, Eli e Julio, de Itú; à Eliana Souza Ribeiro, à diretoria e funcionários da APH, especialmente à Adriana; à Áurea e ao Júlio, de Ribeirāo Preto; ao Dr. Archiduque e ao Aurélio, de Dourados; ao Dr. Paulo Regis, à Eloisa e à Cleide, de Campinas; ao Gil e à Vera, do CSE-GPS; ao Joăo Sollero; ao Rogério; ao Oscar; às colegas farmacêuticas Elsie, Helena e Yone, Márcia, e ainda à Ana Rita, Clara, Estrela, Ilza, Michelly e Valéria. A cada um que ajudou um pouco, contribuindo com informaçōes, com traduçăo, com hospedagem, caronas, facilitando coletas de dados, com boa vontade, com apoio.

Ao meu tio Günter, pelo incentivo. Ao meu sogro José Sollero Filho, pelas correçōes.

Aos membros da banca examinadora, pelas correçōes e sugestōes.

À HN-Cristiano, pelo apoio financeiro.

"Gracias a la vida, que me a dado tanto..." 


\section{RESUMO:}

Cesar AT. O medicamento homeopático nos serviços de saúde. São Paulo; 1999. [Tese de Doutorado - Faculdade de Saúde Pública da USP].

O presente trabalho teve por objetivo estudar e descrever experiências de fornecimento de medicamento em serviços de saúde para subsidiar formulaçōes de políticas, contornando possiveis dificuldades que possam prejudicar a implantaçăo ou a manutenção do atendimento médico homeopático nestes serviços, e fornecer elementos para incrementar a implantação da Homeopatia, por meio de propostas para o medicamento, que tornem mais fácil e possivel o desenvolvimento dos programas. Foi desenvolvido um estudo piloto, que mostrou uma grande diversidade nas prescriçōes. A seguir, foram selecionados outros serviços, com características diversas, e estudada a frequência e apresentação dos medicamentos homeopáticos, através de visitas, entrevistas, cópias de prescriçōes e análise de fichas clínicas. Discutiu-se o enquadramento da Homeopatia quanto aos requisitos para inclusão em lista de medicamentos essenciais, assim como pontos dificultadores de sua implementaçăo. Concluiu-se que: a Homeopatia preenche os critérios necessários para sua adoçăo pelo sistema público; o fornecimento do medicamento homeopático deve ocorrer, financiado pelo custeio coletivo, através de estoque de medicamentos, farmácia estabelecida no local do atendimento médico ou ainda conveniada, próxima ao serviço; é possivvel montar uma relação básica com um número limitado de medicamentos, com poténcia, escala, forma farmacêutica e posologia definidos, para atendimento de diversas patologias, inclusive crónicas; dados disponiveis através de fichas clínicas bem elaboradas são ferramenta importante para a pesquisa; a comprovação de eficácia clínica deve ser melhorada.

Descritores: Homeopatia. Medicamento homeopático. Homeopatia nos serviços de saúde 


\section{SUMMARY:}

Cesar AT. O Medicamento homeopático nos serviços de saúde. [The homeopathic medicine in health services]. São Paulo (BR); 1999. [Tese de Doutorado-Faculdade de Saúde Pública da Universidade de Săo Paulo].

The aim of this study is to investigate and describe experiments of medicine supplying in health care services, as well as to offer elements for the formulation of relevant policies. These should (i) prevent possible difficulties that may harm the setting up or maintenance of homeopathic medical care in health services, and (ii) provide elements to increase the development of Homeopathy, by offering easier and more effective proposals for the use of medicine. A test study was developed, showing a wide diversity of prescriptions. Other services, with distinct characteristics, were selected. The frequency and presentation of homeopathic medicines was studied, through visits, interviews, copies of prescriptions and analysis of clinical files. The suitability of Homeopathy to the requirements of inclusion in an essential remedy list was discussed, as the issues that hinder this development. This study concludes that: (i) Homeopathy meets the necessary standards for its adoption by the public health system, (ii) the supplying of homeopathic remedies should occur, financed by the health care's "collective cost" scheme, through stocks, establishment of local pharmacies, or settled by convention near to the health service concerned, (iii) it is possible to determine a basic relation of a limited number of medicines, with defined potency, scales, pharmaceutical form and posology to address several pathologies, including chronic ones, (iv) available information coming from well elaborated clinical files is an important tool for research, and (v) the verification of clinical efficacy must be improved.

Descriptors: Homeopathy. Homeopathic medicines. Homeopathy in health services. 
4.8 - O Centro Homeopático em Saúde Pública de Dourados 106

4.9 - Os ambulatórios da Associação Paulista de Homeopatia 108

4.9.1 - Estudo das fichas clínicas $\quad 115$

4.9.1.1 - Resumo dos medicamentos mais prescritos $\quad 120$

4.10 - Amostra de prescrições obtidas em 9 farmácias homeopáticas da cidade de São Paulo 121

4.10.1 - Resumo dos medicamentos mais prescritos 123

4.11 - Comparação entre os serviços estudados 125

5 - DISCUSSÃO E RESULTADOS 129

5.1 - Medicamentos essenciais à população: histórico e problemática das ações já implementadas

129

5.2 - Critérios para definição das Listas de Medicamentos Essenciais

130

5.3 - O medicamento homeopático: aspectos positivos 134

5.4 - Aspectos vulneráveis na questão do medicamento homeopático

6 - CONCLUSÕES

7 - RECOMENDAÇŌES

8 - REFERÊNCIAS BIBLIOGRÁFICAS

9 - ANEXOS 


\section{ÍNDICE DE QUADROS:}

QUADRO 1: caracterização do método utilizado no estudo dos locais de atendimento médico homeopático ou de aviamento de receituário homeopático, pág. 44.

QUADRO 2: resumo dos medicamentos homeopáticos mais prescritos nas receitas aviadas pela farmácia homeopática $\mathrm{HN}$-Cristiano, durante os meses de março e abril de 1996, provenientes do CSE-GPS, pág. 56.

QUADRO 3: comparação entre os dados obtidos no estudo piloto no CSEGPS e os de MOREIRA NETO, pág. 58.

QUADRO 4: comparação entre os dados obtidos no estudo piloto e receitas aviadas pela farmácia homeopática HN-Cristiano, em 1986, pág. 60.

QUADRO 5: resumo dos medicamentos homeopáticos mais prescritos nas receitas aviadas pela farmácia homeopática Lírio D'Água, de 25 de maio de 1996 até 14 de novembro de 1997, provenientes do CTA do Posto de Saúde de ltú, pág. 72 .

QUADRO 6: resumo dos medicamentos homeopáticos mais prescritos em estudo de amostra das fichas clínicas provenientes de pacientes atendidos no CTA do Posto de Saúde de Itú, pág. 77.

QUADRO 7: comparaçăo entre os dados dos 10 medicamentos mais prescritos da farmácia homeopática Lírio D'Água e os do estudo de amostra das fichas clínicas provenientes de pacientes atendidos no CTA do Posto de Saúde de Itú, pág. 78.

QUADRO 8: resumo dos medicamentos homeopáticos mais prescritos na Policlínica de Brumadinho, pág. 90.

QUADRO 9: resumo dos medicamentos homeopáticos mais prescritos durante $\mathrm{o}$ ano de 1996 aos pacientes atendidos na IAKAP, pág. 101.

QUADRO 10: resumo dos medicamentos homeopáticos mais prescritos em estudo de amostra das fichas clínicas provenientes de pacientes atendidos na $\mathrm{APH}$, pág. 120.

QUADRO 11: resumo dos medicamentos homeopáticos mais prescritos em estudo de amostra de prescriçōes de 9 farmácias homeopáticas da cidade de São Paulo, pág. 124.

QUADRO 12: comparação entre a situação de fornecimento de medicamentos homeopáticos dos diversos locais estudados, na época do estudo e no final de 1998, pág. 126. 


\section{ÍNDICE DE TABELAS:}

TABELA 1: distribuição da população européia que utiliza medicamentos complementares e desta, aqueles que utilizam Homeopatia, pág. 16.

TABELA 2: composição das receitas segundo os diferentes tipos e modalidades terapêuticas encontradas no aviamento feito pela farmácia homeopática HN-Cristiano, durante os meses de março e abril de 1996, provenientes do CSE-GPS, pág. 52.

TABELA 3: composição das receitas nas quais constam apenas medicamentos homeopáticos em aviamento feito pela farmácia homeopática HN-Cristiano, durante os meses de março e abril de 1996, provenientes do CSE-GPS, pág. 52.

TABELA 4: classificação dos medicamentos homeopáticos, quanto à potência, encontrados nas receitas aviadas pela farmácia homeopática HNCristiano, durante os meses de março e abril de 1996, provenientes do CSEGPS, pág. 53.

TABELA 5: classificação dos medicamentos homeopáticos, quanto à forma farmacêutica, encontrados nas receitas aviadas pela farmácia homeopática HN-Cristiano, durante os meses de março e abril de 1996, provenientes do CSE-GPS, pág. 53.

TABELA 6: classificação dos medicamentos homeopáticos, quanto à posologia, encontrados nas receitas aviadas pela farmácia homeopática HNCristiano, durante os meses de março e abril de 1996, provenientes do CSEGPS, pág. 54.

TABELA 7: classificação dos medicamentos homeopáticos prescritos nas receitas aviadas pela farmácia homeopática HN-Cristiano, durante os meses de março e abril de 1996, provenientes do CSE-GPS, pág. 55.

TABELA 8: classificação dos medicamentos homeopáticos, quanto à forma farmacêutica, encontrados nas receitas aviadas pela farmácia homeopática HN-Cristiano, durante dois meses do ano de 1986, provenientes de diversos médicos homeopatas, pág. 59.

TABELA 9: classificação dos medicamentos homeopáticos, quanto à posologia, encontrados nas receitas aviadas pela farmácia homeopática HNCristiano, durante dois meses do ano de 1986, provenientes de diversos médicos homeopatas ${ }^{(32)}$, pág. 59.

TABELA 10: composição das receitas, segundo os diferentes tipos e 
modalidades terapêuticas, nas prescriçōes aviadas pela farmácia homeopática Lírio D'Água, de 25 de maio de 1996 até 14 de novembro de 1997, provenientes do CTA do Posto de Saúde de Itú, pág. 66.

TABELA 11: classificação das prescrições de medicamentos homeopáticos, em relação aos outros medicamentos que os acompanham, em receitas aviadas pela farmácia homeopática Lírio D'Água, de 25 de maio de 1996 até 14 de novembro de 1997, provenientes do CTA do Posto de Saúde de Itú, pág. 66.

TABELA 12: classificação medicamentos homeopáticos, quanto às potências, encontrados nas receitas aviadas pela farmácia homeopática Lírio D'Água, de 25 de maio de 1996 até 14 de novembro de 1997, provenientes do CTA do Posto de Saúde de ltú, pág. 67.

TABELA 13: classificação dos medicamentos homeopáticos, quanto à forma farmacêutica, encontrados nas receitas aviadas pela farmácia homeopática Lírio D'Água, de 25 de maio de 1996 até 14 de novembro de 1997, provenientes do CTA do Posto de Saúde de ltú, pág. 68.

TABELA 14: classificação dos medicamentos homeopáticos, quanto à posologia, encontrados nas receitas aviadas pela farmácia homeopática Lírio D'Água, de 25 de maio de 1996 até 14 de novembro de 1997, provenientes do CTA do Posto de Saúde de ltú, pág. 68.

TABELA 15: classificação dos medicamentos homeopáticos encontrados nas receitas aviadas pela farmácia homeopática Lírio D'Água, de 25 de maio de 1996 até 14 de novembro de 1997, provenientes do CTA do Posto de Saúde de ltú, pág. 70.

TABELA 16: classificaçăo dos 10 medicamentos homeopáticos mais prescritos nas receitas aviadas pela farmácia homeopática Lírio D'Água, de 25 de maio de 1996 até 14 de novembro de 1997, provenientes do CTA do Posto de Saúde de ltú, pág. 71.

TABELA 17: classificação das prescriçōes segundo os procedimentos provenientes do estudo das fichas clínicas dos pacientes atendidos no CTA do Posto de Saúde de ltú, pág. 74.

TABELA 18: classificação dos diferentes tipos de procedimentos provenientes do estudo das fichas clínicas dos pacientes atendidos no CTA do Posto de Saúde de Itú, pág. 74.

TABELA 19: classificação dos 10 medicamentos homeopáticos mais prescritos provenientes do estudo das fichas clínicas dos pacientes atendidos no CTA do Posto de Saúde de Itú, pág. 75.

TABELA 20: classificaçăo dos medicamentos homeopáticos, quanto suas potências, provenientes do estudo das fichas clínicas dos pacientes 
atendidos no CTA do Posto de Saúde de Itú, pág. 76.

TABELA 21: classificação dos medicamentos homeopáticos, quanto à escala, provenientes do estudo das fichas clínicas dos pacientes atendidos no CTA do Posto de Saúde de Itú, pág. 76.

TABELA 22: classificação dos medicamentos, segundo cópia do Caderno de Registro de Receituário, aviados na Farmácia de Manipulação Homeopática da Policlínica de Brumadinho, pág. 84.

TABELA 23: distribuição das tinturas, segundo cópia do Caderno de Registro de Receituário, aviadas na Farmácia de Manipulação Homeopática da Policlínica de Brumadinho, pág. 85.

TABELA 24: distribuição das pomadas, segundo cópia do Caderno de Registro de Receituário, aviados na Farmácia de Manipulação Homeopática da Policlínica de Brumadinho, pág. 85.

TABELA 25: distribuição dos xaropes, segundo cópia do Caderno de Registro de Receituário, aviados na Farmácia de Manipulação Homeopática da Policlínica de Brumadinho, pág. 86.

TABELA 26: distribuição dos géis, segundo cópia do Caderno de Registro de Receituário, aviados na Farmácia de Manipulação Homeopática da Policlínica de Brumadinho, pág. 86.

TABELA 27: distribuição dos cremes, segundo cópia do Caderno de Registro de Receituário, aviados na Farmácia de Manipulação Homeopática da Policlinica de Brumadinho, pág. 87.

TABELA 28: distribuição das substâncias mais prescritas (incluindo aquelas em complexos), segundo cópia do Caderno de Registro de Receituário, aviadas na Farmácia de Manipulação Homeopática da Policlínica de Brumadinho, pág. 87.

TABELA 29: distribuição dos 10 medicamentos homeopáticos mais prescritos, aviados na Farmácia de Manipulação Homeopática da Policlínica de Brumadinho, pág. 88.

TABELA 30: classificaçăo dos medicamentos homeopáticos, quanto à forma farmacêutica, segundo cópia do Caderno de Registro de Receituário, aviados pela Farmácia de Manipulação Homeopática da Policlínica de Brumadinho, pág. 89.

TABELA 31: classificação dos medicamentos homeopáticos mais prescritos, durante $\mathrm{o}$ ano de 1996, pela IAKAP, pág. 100.

TABELA 32: relação dos tipos de ambulatórios e o número de horas de 
atendimento por semana, na APH, pág. 109.

TABELA 33: classificação dos diferentes tipos de procedimentos provenientes do estudo das fichas clínicas dos pacientes atendidos no ambulatório da APH, pág. 116.

TABELA 34: classificação dos medicamentos homeopáticos, quanto à escala, provenientes do estudo das fichas clínicas dos pacientes atendidos no ambulatório da $\mathrm{APH}$, pág. 116.

TABELA 35: classificação dos medicamentos homeopáticos, quanto à posologia, provenientes do estudo das fichas clínicas dos pacientes atendidos no ambulatório da APH, pág. 118.

TABELA 36: classificação dos medicamentos homeopáticos, quanto à posologia, provenientes do estudo das fichas clínicas dos pacientes atendidos no ambulatório da APH, pág. 118.

TABELA 37: distribuição dos medicamentos homeopáticos mais prescritos, quanto à potência, provenientes do estudo das fichas clíncas dos pacientes atendidos no ambulatório da APH, pág. 119.

TABELA 38: classificaçăo dos medicamentos homeopáticos provenientes de amostras de prescriçōes de 9 farmácias homeopáticas da cidade de São Paulo, pág. 122.

TABELA 39: classificação dos medicamentos homeopáticos, quanto à forma farmacêutica, provenientes de amostra de prescriçőes de 9 farmácias homeopáticas da cidade de São Paulo, pág. 122.

TABELA 40: classificação dos medicamentos homeopáticos, quanto à potência, provenientes de amostras de prescrições de 9 farmácias homeopáticas da cidade de São Paulo, pág. 123.

TABELA 41: comparaçăo entre os resumos dos medicamentos mais prescritos nos diversos serviços de atendimento médico homeopático estudados, pág. 127.

TABELA 42: comparaçăo entre os resumos das potências mais utilizadas nos diversos serviços de atendimento médico homeopático estudados, pág. 128. 


\section{1 - INTRODUÇĀO:}

A Homeopatia Clássica, estabelecida por HAHNEMANN, fundamentase em quatro princípios: lei da Semelhança, experimentação no homem são, administração do medicamento em doses mínimas e indicação de medicamento único. $\mathrm{Na}$ prática, afastando-nos dos principios ideais, percebemos que a Homeopatia é um fenômeno natural, que pode ocorrer também com o uso de substâncias não experimentadas, com o uso de doses ponderais de medicamentos e ainda quando mais de uma substância medicamentosa é utilizada. $O$ principio da Semelhança resta sempre como o preceito essencial da Homeopatia ${ }^{(5,124)}$.

Idealmente, a Homeopatia trata o indivíduo, o doente. Porém, ao longo deste trabalho, perceberemos que diversas vezes o Principio da Semelhança será aplicado à doença, isto é, a parte dos sintomas ou das características do indivíduo. Uma revisão da história da Homeopatia, de sua vinda para nosso país e de aspectos do medicamento homeopático será apresentada para uma melhor compreensão do contexto desta tese.

A autora tem participado de fatos relacionados com a Homeopatia desde 1984, quando fundou a Farmácia Homeopática Cristiano, em São Paulo. Foi presidente da Associação Paulista de Farmacêuticos Homeopatas (APFH), cargo que exerceu durante os anos de 1989 a 1992. Durante este período, participou das reuniōes da CEME em Brasilia, e no ano seguinte, da Comissão de Práticas Alternativas de Saúde do Grupo Especial de Desenvolvimento do Programa (GEPRO) de Práticas Alternativas de Saúde. A Farmácia Homeopática Cristiano 
foi uma das contratadas para Prestação de Serviços de Aviamento de Receitas Homeopáticas.

Frequentou 0 Curso de Atualização em Homeopatia para Farmacêuticos na Associação Paulista de Homeopatia (APH) em 1988, e, no ano seguinte, o primeiro Curso de Homeopatia para Farmacêuticos, passando a fazer parte do grupo que, desde então, tem ministrado cursos anuais para farmacêuticos naquela associação. Em seguinda, fez o curso intensivo de Homeopatia da Escuela Medica Homeopatica Argentina, em Buenos Aires.

Em 1990, a uniăo de sua farmácia com uma concorrente, deu origem às farmácias homeopáticas $\mathrm{HN}$-Cristiano e a um pequeno laboratório industrial, dedicado à produção de tinturas-mãe e matrizes homeopáticas para farmácias. Por este motivo, a autora participou da elaboração de normas de GMP para a indústria homeopática, junto ao Sindicato da Indústria Farmacêutica (SINDUSFARMA).

Desde 1995, ocupa o cargo de Secretária Geral de Farmácia da Liga Médica Homeopática Internacional, freqüentando os Congresso anuais, e as reuniōes do Comitê Executivo e Internacional, fato responsável por aumentar seus conhecimentos da Homeopatia internacional.

Passou a participar da Comissão de Medicina e Farmácia da Associação Médica Homeopática Brasileira (AMHB) em 1997. Foi membro da Comissão Científica que elaborou a 2 edição do Manual de Normas Técnicas da Associação Brasileira de Farmacêuticos Homeopatas. Prestou a prova de título de Especialista em Homeopatia desta associação, e foi aprovada, em 1998. Em 1999 ingressou na 
diretoria desta associação.

Esta grande atividade na área possibilitou uma rica experiência, que despertaram a vontade de realizar um trabalho com a área de medicamentos homeopáticos.

\section{1 - As origens da Homeopatia e seus fundamentos:}

HIPÓCRATES talvez tenha sido o primeiro a afirmar que também é possivel curar através dos semelhantes, apesar de ter formulado igualmente o princípio dos contrários, que fundamenta a assim chamada Alopatia (128, 124).

No pensamento de HIPÓCRATES as duas leis parecem não se opor, porém ter indicaçōes particulares, ambas com a finalidade de curar. Assim, um dos principios diretivos da terapéutica hipocrática é que "os semelhantes curamse pelos semelhantes". "A doença é produzida pelos semelhantes, e pela administraçăo do semelhante, o paciente retorna da doença à saúde". Ou "as substâncias naturalmente purgativas podem provocar a obstipação" (57.128).

Em PARACELSUS também reencontramos este princípio hipocrático: "o semelhante pertence ao semelhante". Afirma-se que toda sua prática médica tenha sido fundamentada na doutrina dos similares, na idéia de que a substảncia que causa a doença também irá curá-la ${ }^{(51,128,124)}$.

CROLLIUS, seu seguidor, afirma: "...é necessariamente imperioso - se queremos que os remédios sejam contrários à doença - que eles sejam convenientes à natureza, que the sejam semelhantes... Qualquer que seja a doença, deve ser curada pelo seu próprio correspondente" ${ }^{(57,128)}$. 
HAHNEMANN, médico alemão nascido na cidade de Meissen, em 1755, na Saxônia, retomou as idéias de seus antecessores e estabeleceu um método terapéutico fundamentado na "Lei dos Semelhantes". Ficou conhecido como o fundador da Homeopatia. Nunca afirmou ter descoberto esta lei, mas sim ter sido o primeiro a ensiná-la e aplicá-la de forma consistente ${ }^{(51)}$.

Em seu trabalho iniciou experimentando várias drogas, para em seguida publicar o "Ensaio sobre um novo principio para se averiguar os poderes curativos das drogas", onde afirmava que

(...) devemos imitar a natureza, que às vezes cura uma doença pela superadição de uma outra, e empregar na doença (especialmente crónica) que queremos curar, aquele medicamento capaz de produzir uma outra doença artificial, muito similar, e a primeira será curada: similia similibus ${ }^{(51,69,87)}$.

Discordando dos agressivos tratamentos médicos de sua época, quando eram costumeiras as sangrias, ventosas e utilizaçăo de substâncias tóxicas que debilitavam os doentes, HAHNEMANN buscava, como "o mais alto ideal da cura, o restábelecimento rápido, suave e duradouro da saúde, ou a remoção e destruição integral da doença pelo caminho mais curto, mais seguro e menos prejudicial, segundo fundamentos nitidamente compreensiveis" ${ }^{70,87}$.

HAHNEMANN utilizou o princípio da semelhança, isto é, considerava que medicamentos preparados a partir de substâncias que podem causar alguns sintomas quando administradas em grandes doses a um indivíduo saudável, poderiam curar os mesmos sintomas quando dados em doses muito pequenas para outro individuo doente, com os mesmos sintomas. Para diminuir a toxicidade que algumas destas substâncias apresentavam, e que dificultava sua utilização, HAHNEMANN começou a diluí-las. Não é muito 
explicado pela história, mas, possivelmente de forma intuitiva, conforme ele diluía, passou também a agitar suas diluiçöes. Este método, constituído por diluição e agitação, foi sendo aperfeiçoado por HAHNEMANN durante o desenvolvimento de seu trabalho, e recebeu o nome de "dinamização". Portanto, os medicamentos utilizados com critério homeopático são geralmente dinamizados ${ }^{(124)}$.

A palavra dinamização vem do grego "dynamis" e está relacionada à idéia de força. Este conceito de que uma substancia diluída - a dinamização sempre inclui uma diluiçăo - pode apresentar uma "força", é bastante difícil de ser aceito pela Farmacologia, com suas clássicas curvas de doses e respostas. As diluiçōes homeopáticas facilmente ultrapassam o número de Avogadro', e portanto torna-se estatisticamente improvável encontrar uma única molécula da substância inicial nos medicamentos. RESCH \& GUTMANN perguntam: "quem pode imaginar que o efeito de um medicamento seja independente da substância original utilizada para sua preparação?" (111).

Outro aspecto importante a ser notado nos princípios estabelecidos por HAHNEMANN, para melhor utilizar o fenômeno homeopático, foi o da experimentação das substâncias a serem utilizadas como medicamentos ${ }^{2}$. Administrou substâncias a indivíduos saudáveis, em pequenas quantidades, diariamente, até que estes manifestassem uma série de sinais e sintomas especificos para aquela substância. Estes sintomas, obtidos para cada

\footnotetext{
${ }^{1}$ O número de Avogadro $\left(6,02 \times 10^{23}\right)$ indica o número de moléculas contidos em um mol ou uma molécula-grama de substância. Molécula-grama é o peso molecular da substância, expresso em gramas. Em decorrência deste número, teorias da Química Clássica afirmam que as diluiçóes homeopáticas além do limite de $10^{-24}$ consistiriam apenas do solvente, e portanto năo poderiam exercer um efeito sobre o organismo.

${ }^{2}$ Embora seja um termo mais genérico, preferiu-se o emprego da palavra "substância" em vez de "droga", uma vez que droga tradicionalmente significa uma substância farmacologicamente ativa. Algumas substâncias utilizadas no preparo de medicamentos homeopáticos săo reconhecidamente inertes, como o Lycopodium clavatum, antes do processo da dinamizaçăo. Existe em inglês e francess o termo "source" e "souche", que parecem nåo ter equivalente em português, significando "substância que dá origem ao medicamento, homeopático no caso".
} 
substância, a partir de uma ordem destinada a facilitar a consulta, foram listados desde a época de HAHNEMANN em compêndios denominados Matérias Médicas. Até sua morte, HAHNEMANN realizou a experimentação de 99 subståncias, trabalho continuado por seus seguidores até nossos dias (87,101).

Para facilitar a escolha do medicamento indicado para cada paciente, os mesmos sintomas foram agrupados em capítulos (por exemplo, sintomas relacionados ao quadro mental, ilusões, vertigem, cabeça, olho, visão, etc.) e em rubricas e sub-rubricas, que modalizam os sintomas classificados nos diversos capítulos. Estes livros são chamados de Repertórios. Estas duas obras formam a base da literatura médica homeopática ${ }^{(68,112)}$.

Mesmo a Matéria Médica Pura ${ }^{3}$ elaborada por HAHNEMANN, e todas as que a seguiram, são utilizadas até hoje, uma vez que os sintomas provocados pelas substâncias, em indivíduos saudáveis, são sempre os mesmos. Embora ocorram trabalhos de revisões destes sintomas, isto é, reexperimentaçōes das substâncias, a coleção de medicamentos homeopáticos clássicos é relativamente estática, sem o dinamismo peculiar que encontramos na medicina e na indústria farmacêutica alopática de buscar e produzir um novo medicamento para cada patologia ${ }^{(51,68)}$.

Em uma consulta homeopática o médico faz a anamnese, interrogando o paciente sobre seus sintomas, sinais, sensaçōes e características pessoais, procurando combiná-los com os sintomas produzidos por uma substância que foi anteriormente experimentada em indivíduo são, e que está descrita em uma Matéria Médica. A substância cujos sintomas (produzidos em homem são) forem mais semelhantes aos do paciente, será escolhida para ser administrada como medicamento.

\footnotetext{
${ }^{3}$ Matéria Médica Pura significa que a informaçăo encontrada naquela referéncia é baseada apenas em experimentaçð̋es e não em outros tipos de dados como sintomatologia clínica ou toxicológica ${ }^{(123)}$
} 
O tratamento homeopático é, portanto, individualizado. Duas ou mais pessoas com o mesmo diagnóstico podem ser tratadas com diferentes medicamentos, dependendo dos sintomas específicos de cada uma delas.

ADLER et al. afirma que Homeopatia é hoje um termo amplamente conhecido, mas seu significado é ambiguo e vago. Ambíguo porque é usado como sinônimo de outros conceitos, como doses infinitesimais ou medicamentos dinamizados; vago porque a definição não é estrita, mas sim mescla-se com a idéia de ser uma terapêutica, arte médica ou modo de vida baseado na chamada Lei dos Semelhantes ${ }^{(5)}$.

Para ocorrência do fenômeno homeopático, busca-se que uma afecção dinâmica (doença natural) seja afastada do organismo, por uma outra afecção dinâmica, mais forte (doença medicamentosa, provocada de modo temporário), quando esta última for muito semelhante à primeira em suas manifestações ${ }^{(70)}$.

Utilizando este modelo, na Homeopatia o paciente trocaria a sua doença por uma muito semelhante e mais forte. Sendo assim, "qual é a lógica de se tratar homeopaticamente?" pergunta ADLER et al ${ }^{(4)}$. E conclui afirmando:

HAHNEMANN criou e desenvolveu um método de produzir e controlar o fenômeno homeopático, de modo a causar uma doença artificial muito semelhante, e apenas ligeiramente mais forte do que a doença do paciente. Quando este objetivo terapêutico é atingido, o medicamento é descontinuado ${ }^{4}{ }^{(5)}$.

\footnotetext{
"Este procedimento clássico, proposto por HAHNEMANN, nem sempre foi seguido por alguns de seus discípulos, fundadores de escolas que medicam os pacientes com diversos medicamentos, administrados diversas vezes ao dia, durante longos periodos de tempo. Embora a posição de HAHNEMANN seja clara, na prática, verifica-se divergências entre os clínicos.
} 
A cura vai ocorrer pela reação do organismo - da Força Vital, segundo HAHNEMANN - em reação ao remédio apropriado ${ }^{(5,70)}$.

Segundo este raciocínio, ADLER et al. propőe uma definição para Homeopatia:

Homeopatia é o resultado da interação dinámica entre duas afecçőes vitais, qualitativamente diferentes, mas muito semelhantes em seus efeitos no organismo vivo. Este resultado pode ser a atenuação da afecção mais forte ou a extinção da afecção mais fraca ${ }^{(5)}$.

\section{2 - O desenvolvimento da Homeopatia nos diversos países:}

A terapêutica proposta por HAHNEMANN fez sucesso junto aos pacientes, mas também recebeu muitas criticas vindas da medicina ortodoxa.

"O rápido avanço inicial da Homeopatia foi devida, provavelmente, ao fato de que a medicina ortodoxa daquela época era extremamente atrasada e carecia de medicamentos efetivos, e, por outro lado, à superioridade da Homeopatia em tratar as várias epidemias de febre tifoide, colera e febre amarela que devastavam a Europa e a América no século XIX" contam BELLAVITE e SIGNORINI ${ }^{(27)}$.

COULTER $\Theta$ outros autores relatam detalhes interessantes desta fase ${ }^{(51,87)}$.

HAHNEMANN apresentava uma rígida intolerância para com seus oponentes - aos quais chamou "alopatas", palavra utilizada até hoje - e também para com aqueles que se diziam seus seguidores, mas que se recusavam seguí-lo com precisão e sem nenhum questionamento. Existiu, inclusive, uma revista dedicada a atacá-lo, o Anti-Homoeopathisches Archiv, de Hamburgo ${ }^{(51)}$.

Mesmo assim, a Homeopatia progredia, em parte por seu sucesso 
terapéutico durante epidemias de tifo, escarlatina e cólera. HAHNEMANN terminou seus dias na França, onde clinicou com sucesso, ainda que sempre cercado de críticas. Por exemplo, TROUSSEAU, apesar de chamar os homeopatas de "homens honrados e amistosos, nos quais podemos confiar", também classificou sua prática como "especulativa e contra princípios científicos". A Academia de Medicina Francesa, em 1835, chamou aos seguidores da Nova Escola de charlatães. Apesar disso, em 1840 havia 50 homeopatas franceses; em 1850, mais de 200. O sucesso gerou contraataques, tal como a expulsão dos homeopatas das sociedades médicas $(51,87)$

Atualmente, a Farmacopéia Francesa tem uma seção própria para medicamentos homeopáticos. Em seu prefácio encontramos a seguinte citação:

A França oficializa a Homeopatia, introduzindo-a em sua Farmacopéia. A comissăo permanente da Farmacopéia adotou regras precisas para os medicamentos homeopáticos, para assegurar a constância das substáncias utilizadas como matéria prima $^{(17,52,102)}$.

BAUR descreve com detalhes a história da Homeopatia e dos medicamentos homeopáticos na França (26).

Medicamentos homeopáticos industrializados são encontrados em qualquer farmácia francesa, porém são raríssimas as que os preparam. Existem grandes laboratórios farmacêuticos para a fabricação de medicamentos homeopáticos, como Boiron e Dolisos, com subsidiárias em diversos países europeus, nos Estados Unidos, Canadá e Índia, além de distribuidores ou correspondentes na América do Sul, Israel, países da África, Paquistão, Formosa, Japão, Polinésia e Austrália ${ }^{(33,56)}$. 
O laboratório Boiron faturou em 1996 1,25 bilhões de francos, sendo 312 milhöes fora da França, com um lucro líquido de 76,6 milhões. Seu concorrente Dolisos faturou naquele ano 600 milhões de francos. $O$ terceiro faturamento mundial da área é do laboratório alemão Heel. O mercado mundial é estimado em 6 bilhões de francos, sendo $30 \%$ dele na França e $20 \%$ na América do Norte ${ }^{(1,92)}$.

Pesquisa de 1978 de LAPLANTINE et al., citada por MENDICELLI, mostrava que $34 \%$ dos franceses já haviam recorrido às medicinas paralelas. Estudo semelhante feito em 1985 revelou que $49 \%$ da população francesa com mais de dezoito anos se utilizava dessas terapias. Entre estas medicinas paralelas, a Homeopatia ocupava o primeiro lugar, com 22\% em 1978 e $32 \%$ em 1985. Em 1989 48\% dos entrevistados responderam afirmativamente à pergunta "na sua opiniăo, existem doenças que é melhor tratar sem recorrer à medicina?" . Em 1991, BOY perguntou "em caso de doença, vocé recorreria, pelo menos em certos casos, às seguinte práticas?", e obteve $81 \%$ de respostas positivas ("sim, pelo menos em alguns casos") e 16\% de respostas negativas ("năo, de jeito nenhum") para a Homeopatia. Em 1990, os leitores da revista de divulgação científica La Recherche, declararam ser capazes de recorrer à homeopatia (5\% em todos os casos e $54 \%$ em certos casos) ${ }^{(34,91)}$.

Em 1995 o Sindicato da Indústria Homeopática Francesa apresentou dados que afirmavam que cerca de $30 \%$ dos europeus utilizariam medicamentos homeopáticos, especialmente na Alemanha, Holanda e Bélgica. Na França seriam cerca de $36 \%$ da população. A porcentagem de franceses que não utilizavam e eram contrários ao uso da Homeopatia diminuiu de $33 \%$ em 1983 para 25\% em 1994. A Comissão Européia de Homeopatia publicou, em 1996, um relatório com resultados de entrevistas com 1577 líderes formadores de opinião na área de saúde, que afirmavam que medicamentos homeopáticos seriam utilizados por $42 \%$ da população na Alemanha, $31 \%$ 
no Reino Unido e na Bélgica, e $23 \%$ na França. Sete Faculdades de Farmácia francesas organizaram ciclos de 1 ano, pós universitário. Em sete Faculdades de Medicina, foram criados cursos de 3 anos ${ }^{(1,127)}$.

VITHOULKAS afirma, em publicação de 1983, que cerca de 6000 médicos empregavam medicamentos homeopáticos na França. Relatório do Comitê Europeu de Homeopatia de 1994 afirma que $36 \%$ dos médicos gerais usam métodos não convencionais: $5 \%$ exclusivamente, $21 \%$ com freqüência e $73 \%$ ocasionalmente ${ }^{(59,130)}$.

Desde 1989 as preparações homeopáticas magistrais ${ }^{5}$ pertencentes a uma relação de 1163 substâncias, e aviadas sob formas farmacêuticas definidas (grânulos, glóbulos, gotas, supositórios, trituraçōes e pomadas, de 1DH até $30 \mathrm{CH}^{6}$ ) são reembolsadas pela Seguridade Social ${ }^{(56)}$.

Nos Estados Unidos a Homeopatia foi introduzida no século passado, em 1825, e já em 1840, competia com a medicina tradicional. Em poucas décadas, uma profissão homeopática independente surgiu, com seu próprio sistema de escolas médicas, registros profissionais e hospitais: até o final do século havia 16 escolas médicas para ensino de Homeopatia. Durante algum tempo, os dois sistemas médicos - alopático e homeopático - foram considerados iguais sob todos os aspectos legais ${ }^{(51,52)}$.

O Instituto Americano de Homeopatia foi fundado em 1844, e HERING, médico alemão conhecido como o pai da Homeopatia nos Estados Unidos, eleito seu primeiro presidente. Uma das resoluçōes do Instituto - a de não admitir membros sem estudo médico alopático regular - mostra o propósito

\footnotetext{
${ }^{5}$ Săo chamadas preparaçð̋es "magistrais" aquelas prescritas por médico.

${ }^{6}$ Os medicamentos homeopáticos săo diluídos e agitados. As diluiçőes săo mais comumente realizadas na proporçăo de 1:10 (decimais) ou de 1:100 (centesimais). De 1DH até $30 \mathrm{CH}$, significa portanto da primeira diluiçăo decimal até a trigésima diluiçăo centesimal.
} 
de manter um alto nivel profissional entre seus associados, que deveriam então seguir a Homeopatia por escolha consciente ${ }^{(51)}$.

COULTER descreve com detalhes os aspectos econômicos do conflito entre alopatia e Homeopatia, como a divisão do mercado de trabalho e o sucesso obtido pelos homeopatas junto à clientela, mesmo cobrando honorários maiores pelas consultas médicas. O contra-ataque da medicina tradicional não tardou: a reorganização do ensino médico, a criação da Associação Médica Americana, a re-educação dos médicos homeopatas, a expulsão das sociedades médicas, a exclusão dos artigos sobre Homeopatia das revistas médicas. O Relatório Flexner, elaborado a pedido da Associação Médica Americana, impós critérios que enfatizavam a abordagem físicoquímica e patológica no ensino, penalizando as escolas que ensinavam a Homeopatia. Essas questőes políticas e legais fizeram com que a Homeopatia praticamente desaparecesse nos Estados Unidos. Afirma FONTES que:

"segundo Galhardo, no começo deste século existiam nos Estados Unidos mais de 8000 médicos homeopatas, 28 hospitais e 8 escolas médicas homeopáticas, além de vários cursos, peribdicos, laboratónios farmacéuticos e fundaçōes, todos envolvendo a Homeopatia. Sob o impacto do Relatório Flexner, a partir de pressões legais e financeiras, essas instituiçóes viram-se forçadas a encerrar suas atividades. hoje, sob o incentivo do governo, a Homeopatia americana está em um processo de renascimento". $27,51,64)$.

Esta prática começou a ressurgir novamente somente nos últimos anos, já que a década de 60 trouxe entusiasmo por tudo que fosse "natural" ou "holistico"; a ascensão da "contracultura" permitiu renascer a terapéutica de quase dois séculos. Hoje, apesar de ainda haver resistência, diversos cursos garantem a formação de novos médicos homeopatas, assim como são encontrados milhares de praticantes não-médicos. Pesquisa aponta que 
cerca de $50 \%$ dos médicos desejariam receber treinamento em Homeopatia. O Congresso anual da Liga Médica Homeopática Internacional de 1997 foi realizado na cidade de Seattle, contribuindo para o novo desenvolvimento da Homeopatia naquele pais ${ }^{(1,19,29,51,77,127)}$.

ULLMAN afirma que, de acordo com o FDA (Food and Drug Administration, agencia nacional de fiscalização de medicamentos e alimentos norte americana), as vendas de medicamentos homeopáticos cresceram cerca de $1.000 \%$ do final da década de 70 para o início dos anos 80 . Na década de 90, os números atingiram 250 milhōes de dólares ao ano, com crescimento anual de 20 a $25 \%$. Em 1994, mais que $75 \%$ das farmácias vendiam algum tipo de medicamento homeopático ${ }^{(127)}$.

Um levantamento de EISENBERG et al. mostrou que $34 \%$ da população americana foi atendida através de práticas médicas alternativas em 1990. A estimativa é de que cerca de $1 \%$ da população utilizava medicamentos homeopáticos nos Estados Unidos nessa época ${ }^{(58)}$.

ASTIN publicou, em 1998, um estudo com o título de "Por que pacientes usam medicina alternativa?" Seu levantamento incluiu 1035 pessoas, questionadas sobre o uso de medicina alternativa no ano anterior. 0 principal motivo encontrado foi por considerarem estas práticas alternativas de saúde mais compativeis com seus valores, crenças e orientações filosóficas em relação à saúde e à vida, ou por serem menos autoritárias, oferecendo mais controle sobre suas decisões de saúde. Estes fatores foram mais importantes do que sua insatisfação com os tratamentos convencionais. Nesse estudo, a porcentagem de usuários variou entre 29 e $71 \%$, dependendo da faixa etária (foi maior entre os 50 e 64 anos), etnia (especialmente entre índios americanos), educação (valores máximos foram encontrados para grupos com curso superior completo) e renda (especialmente entre os de maior renda). A Homeopatia foi citada como 
especialmente indicada para o tratamento de artrite e reumatismo ${ }^{(18)}$.

JACOBS et al. publicaram trabalho sobre o tratamento de diarréia aguda infantil com medicamentos homeopáticos, em estudo realizado na Nicarágua. Embora seus resultados tenham mostrado uma diminuição estatisticamente significante na duração da diarréia do grupo tratado com medicamentos homeopáticos em relação ao grupo tratado com placebos, o número total de casos não era muito elevado. No intuito de aperfeiçoar os dados já encontrados, foi estabelecido o "Projeto Multi-Centro Homeopático sobre Diarréia". Jennifer JACOBS, sua coordenadora, professora do Departamento de Epidemiologia da Escola de Saúde Pública da Universidade de Washington, enviou cartas-convite para vários países, buscando outras regiőes onde esta patologia fosse importante, e colaboradores interessados nesse projeto ${ }^{(7)}$.

Na Alemanha, a Lei dos Medicamentos de 1978 estabeleceu um registro separado para medicamentos homeopáticos, o que thes conferiu proteção legal. Cerca de $10 \%$ dos médicos, estudaram homeopatia, e outros $10 \%$ prescrevem medicamentos homeopáticos ocasionalmente. Existem ainda 11.000 terapeutas registrados, os "Heilpraktiker", sendo 3.000 deles especializados em homeopatia. As vendas de medicamentos homeopáticos alcançaram 428 milhões de dólares em 1991, com crescimento de $10 \%$ ao ano. Destas, $85 \%$ foram provenientes de alguma prescriçăo clínica, e dispensadas por $98 \%$ das farmácias ${ }^{(52,127)}$.

O desenvolvimento da Homeopatia na Inglaterra é detalhadamente descrito por NICHOLLS e também por KAYNE. A Faculdade de Homeopatia é ligada ao Royal London Homoeopathic Hospital. O Comitê Europeu para Homeopatia afirma que $37 \%$ dos médicos inglêses usam Homeopatia. FULDER \& MUNRO afirmaram existir 12 terapeutas para cada 100.000 habitantes, o equivalente a $26,8 \%$ do número de médicos generalistas. 0 
ponto interessante é que os pacientes das medicinas complementares, ao contrário de serem individuos crédulos ou que as estejam utilizando como último recurso, mostraram ser pessoas com nível de educação de terceiro grau, com freqüência maior do que a encontrada no mesmo grupo etário de pacientes de médicos generalistas. O estudo mostrou crescimento da Homeopatia, porém como um sistema complementar de saúde. Este resultado também foi encontrado no estudo de THOMAS et al. (52. $59,66,77,101,126)$

O Ministro da Saúde britânico, Dr. MAWHINNY, afirmou que a medicina complementar (que naquele país inclui a homeopatia) é bastante popular entre os pacientes, recebendo a aprovação de $81 \%$ deles ${ }^{(12 \pi)}$.

Há venda de medicamentos homeopáticos tanto em "health stores" (lojas de produtos naturais), como em farmácias. Trata-se de um país onde existem algumas farmácias exclusivamente homeopáticas nos mesmos moldes do Brasil. Consta que a própria Família Real é usuária desses medicamentos, o que tem significado especial no Reino Unido.

A Comissão de Sistemas Alternativos de Medicina, criado pelo Ministério da Saúde e Proteção do Ambiente dos Países Baixos, em 1977, considerou que a Homeopatia é uma terapêutica popular. Pelo estudo, teria havido 320.000 consultas de médicos homeopatas por ano, além das de outros clínicos que utilizam remédios homeopáticos eventualmente. A população holandesa que consultou um terapeuta alternativo aumentou de $3,8 \%$ para $5,2 \%$ entre 1981 e 1987. Dados do Comitê Europeu para Homeopatia afirmam que $47 \%$ dos médicos utilizam métodos terapêuticos não convencionais, sobretudo Homeopatia (40\% deles) ${ }^{(45,59,91)}$.

Na Bélgica, $84 \%$ da Homeopatia é praticada por médicos ${ }^{(59)}$. 
$\mathrm{Na}$ Suiça entre 11 e $27 \%$ dos clínicos prescrevem medicamentos homeopáticos. Já na Itália apenas $9 \%$ (m).

Dados de 1994 de FISHER e WARD, citados por KAYNE e que podem ser visualizados na TABELA 1, mostram a porcentagem da população européia e americana, que utiliza medicamentos complementares, e desta a porcentagem que utiliza a homeopatia ${ }^{(59.77)}$ :

TABELA 1: distribuiçăo da populaçăo européia que utiliza medicamentos complementares e desta, aqueles que utilizam Homeopatia.

\begin{tabular}{|c|c|c|}
\hline (x) & W. & 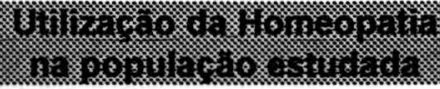 \\
\hline Bélgica & i: & I: \\
\hline Q & $x$ & 然: \\
\hline Franca : : : : : : : & 49 & (I: \\
\hline A & 6 & 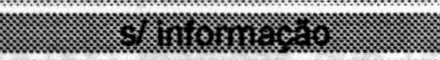 \\
\hline Solanda : & 20. & : $:$ : 31 : $:$ : \\
\hline 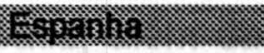 & 8 & $(x)$ \\
\hline Reino Unido : & 26 & 16 \\
\hline W & 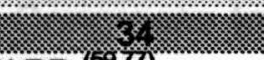 & x \\
\hline
\end{tabular}

KAYNE compara também dados referentes à venda de medicamentos homeopáticos no mercado europeu, destacando França e Alemanha como os países onde estes valores são mais elevados ${ }^{(m)}$.

Segundo MENDICELLI, estudo de BARROS-ST.PASTEUR indica que, nos países do continente americano, a Homeopatia é exercida na Argentina, Brasil, Colômbia, Costa Rica, Chile, Equador, Estados Unidos, México, Uruguai e Venezuela; em relaçăo aos países europeus, na Alemanha, Áustria, Bélgica, França, Finlândia, Inglaterra, Grécia, Holanda, Itália, Noruega, Suécia e Suiça ${ }^{(91)}$.

A Liga Médica Homeopática Internacional (LMHI) tem representantes (VicePresidentes nacionais e contatos) em 47 países, além de uma diretoria e um Comitê Executivo, do qual fazem parte Secretarias Internacionais de 
Pesquisa, Educação, Farmácia, Veterinária, Odontologia e outras.

BANERJEA relaciona cursos de Homeopatia em diversos países e em vários continentes ${ }^{(19)}$.

No México, onde a Homeopatia é exercida ativamente, encontram-se várias escolas médicas homeopáticas, que dedicam-se tanto a cursos de especialização em Homeopatia para médicos, como à graduação de médico homeopata $^{(52,127)}$.

$\mathrm{Na}$ Índia, a Homeopatia disseminou-se largamente, embora se discuta que poderia ser muito mais utilizada no programa nacional de saúde. É o país onde mais se consomem medicamentos homeopáticos. KISHORE cita 30.000 homeopatas leigos qualificados e 75.000 médicos que utilizam a Homeopatia, além da existência de 80 hospitais e 2000 dispensários. Em visita àquele pais, durante Congresso Internacional de Homeopatia da Liga Médica Homeopática Internacional (LMHI) em 1995, foi-me possível observar a grande quantidade de praticantes, com formação médica superior e técnica. Há grande aceitação da população por esta terapêutica, praticada ao lado da medicina tradicional - ayurvédica - e da alopática. Os medicamentos são dispensados nos consultórios, existindo poucas farmácias e laboratórios farmacèuticos ${ }^{(19,52,55,77,78)}$.

No Paquistão, a Homeopatia foi oficialmente reconhecida em 1965 e há reembolso de medicamentos pelo serviço nacional de saúde ${ }^{(52)}$.

Também Austrália e Nova Zelândia são paises onde este sistema terapêutico passou por periodos de sucesso no final do século passado, sofreu uma retração, e novamente são procurados hoje pela população ${ }^{(7)}$. 


\section{3 - A Homeopatia no Brasil:}

Apesar de existirem referências de que José Bonifácio de ANDRADE e SILVA tenha se correspondido com HAHNEMANN, é o francês Benoit MURE tido como o introdutor da doutrina homeopática no Brasil. Médico, "Bento" MURE chegou ao país em 1840, acompanhado de outras famílias, para organizar uma colônia comunitária, na província de Sahy, em Santa Catarina. Com o fracasso do projeto, mudou-se para o Rio de Janeiro, onde passou a exercer e a divulgar a Homeopatia. O cirurgião portuguès João Vicente MARTINS tornou-se seu primeiro assistente. Quando os homeopatas passaram a sofrer perseguiçōes, em 1847, MARTINS transferiu-se para Salvador, fundando a Sociedade Homeopática Baiana. MURE estudou e utilizou plantas e animais brasileiros. Incansável divulgador das idéias de HAHNEMANN, enviava gratuitamente pacotes com os principais medicamentos e uma Matéria Médica para todos os médicos alopatas que se interessassem pela Homeopatia ${ }^{(31,32,84,85,86,87,89,100)}$.

Desde seu inicio no Brasil, e da mesma maneira como ocorreu em todos os países, a Homeopatia tem passado por períodos de crises e perseguições, alternados por outros de maior sucesso e desenvolvimento ${ }^{(31,32,84,85,86,87)}$.

O Instituto Hahnemanniano do Brasil, ativo até hoje, foi fundado em 1859. 0 Regulamento do Serviço Sanitário do Império, anexo ao Decreto $n^{\circ} 9.554$, de 3 de fevereiro de 1886, referendado pelo Barão de Mamoré, oficializou as farmácias homeopáticas e os especialistas médicos homeopatas $(31,32,84,85,86,87,89)$

Em relação à área farmacêutica conta MEIRELLES que, no final do século passado, grande parte dos medicamentos homeopáticos vinham do exterior, da Europa ou dos Estados Unidos. Tinturas-mãe ${ }^{7}$, dinamizações, e até 
mesmo parte dos medicamentos eram importados já prontos. Quanto ao preparo, tudo que se fazia nas farmácias naquela época, era o embebimento dos glóbulos ${ }^{8}$ inertes com soluções importadas já dinamizadas (89).

No ano de 1912, foi fundada a Faculdade Hahnemanniana, e em 1916, o Hospital Hahnemanniano. Em 1926 houve o I Congresso Brasileiro de Homeopatia, no Rio de Janeiro. Foi uma época áurea para a Homeopatia no Brasil. Afirma LUZ que "apesar dos cerceamentos e punições de parte de instituições do ensino médico, conseguem legitimar o ensino e a prática homeopática, bem como a produção livre de seus medicamentos nas farmácias, que se espalham por todo o Brasir. Encontra-se em LUZ texto de GALHARDO:

Mais de cem farmácias e laboratórios exclusivamente homeopáticos, que aviam o receituário médico e espirita, existem no Brasil, especialmente na Capital Federal. Não há lugar no território brasileiro onde a homeopatia não possua convictos adeptos, como raríssimo é o lar onde não exista uma caixinha com medicamentos homeopáticos e um livro sobre homeopatia. Raríssima é, igualmente, a Farmácia Alopática que não apresente medicamentos homeopáticos e Farmácias Homeopáticas e outros preparados nas proprias Farmácias Alopáticas, mal $e$ erradamente preparados, já se vê. No Brasil, portanto, a Homeopatia tem progredido muito: é oficializada, ensinada em uma Escola equiparada às Escolas Oficiais, possui um Hospital exclusivamente Homeopático e enfermarias Homeopáticas em vários Hospitais Alopáticos: é exercida profissionalmente por uns

\footnotetext{
7 Tinturas são preparaçōes hidroalcoólicas que têm como resultado a extração dos princípios ativos de vegetais ou animais. Para o preparo de medicamentos homeopáticos as tinturas - preparadas de partes específicas de plantas - săo diluídas e agitadas, gerando as dinamizaçøes. Por este motivo, na Homeopatia as tinturas recebem o nome de "Tinturas-Măe".

8 Glóbulos săo tradicionalmente utilizados para dispensação de medicamentos homeopáticos. Trata-se de uma forma farmacêutica preparada a partir de sacarose, por drageamento. As farmácias adquirem estes glóbulos na forma inerte, e sobre eles adicionam soluçø̋es medicamentosas dinamizadas.
} 
200 médicos, além do considerável número de médiuns espíritas que receitam Homeopatia, e não errarei declarando que mais de sete milhões de habitantes - um quinto da população da época no Brasil não se utilizam de outra terapêutica ${ }^{(87)}$.

A partir de 1930, também no Brasil, provavelemente também como reflexo do Relatório Flexner, iniciou-se o declínio da Homeopatia e indicação disto é que o II Congresso Brasileiro de Homeopatia ocorreu apenas em 1950 (64,.87,94)

A Lei $n^{\circ}$ 1.552, de 8 de julho de 1952 determinou a obrigatoriedade do ensino de noçōes de Farmacotécnica Homeopática nas Faculdades de Farmácia de todo o país ${ }^{(29)}$.

O Dr. David CASTRO afirmou que, em 1954, existiam 200 farmácias especializadas, dezenas de ambulatórios e 10 ou 12 grandes laboratórios produtores de medicamentos homeopáticos ${ }^{(87)}$.

Pouco conhecida entre nós foi a sondagem de opinião realizada pelo IBOPE em 1957 que perguntava: "Você acredita em Homeopatia como remédio?" E ainda: "Vocé já teve oportunidade de usar Homeopatia?" De 800 entrevistados, $76 \%$ respondeu de modo afirmativo à primeira pergunta e $73 \%$ à segunda pergunta, possivelmente confundindo Homeopatia com a Fitoterapia ${ }^{(87)}$.

A publicação do Decreto $n^{\circ} 78.841$ de 25 de novembro de 1976, que aprovou a primeira edição da Farmacopéia Homeopática Brasileira, foi um marco, tanto pela oficialização do medicamento, como pelo fato de tão poucos países possuírem obra semelhante. Iniciou-se um novo tempo, que LUZ chama de "retomada social da Homeopatia" ${ }^{(61,87)}$.

A Associação Médica Brasileira (AMB) reconheceu a Homeopatia como 
especialidade médica em 28 de julho de 1979. No ano seguinte o Conselho Federal de Medicina (CFM) tomou a mesma decisão e estabeleceu regras para a obtenção do título de médico homeopata ${ }^{(35,50,89)}$.

Em relação às associações homeopáticas nacionais, em 1980 foi fundada a Associação Médica Homeopática Brasileira (AMHB). Pouco ativa em seus primeiros anos, passou a ter uma maior atuação a partir de 1988, contando hoje com quase 1000 sócios. O primeiro exame para obtenção do título de Especialista em Homeopatia foi realizado através de um acordo entre a AMHB, AMB e CFM, em 29 de junho de 1990, com 158 candidatos, dos quais $\mathbf{8 8}$ foram aprovados. Os Cursos de Especialização em Homeopatia para Médicos foram regulamentados, através do estabelecimento de currículo, com duraçăo de 1200 horas. Para melhor organizar-se, a AMHB estabeleceu diversas Comissões, entre elas a de Saúde Pública e a de Farmácia e Medicina ${ }^{(10,35)}$.

O Centro de Saúde Experimental da Barra Funda, ligado à Faculdade de Ciências Médicas da Santa Casa de São Paulo, iniciou em 1981, em caráter informal, o serviço médico homeopático, oferecido a um número restrito de pacientes ${ }^{(119)}$.

Em 1986 a Homeopatia foi implantada no serviço público de saúde do INAMPS. A Resolução CIPLAN $n^{\circ} 4$, de 1988, fixou diretrizes sobre o atendimento médico homeopático nos serviços públicos. Nesta época a Central de Medicamentos (CEME), em convênio com a Fundação Instituto Oswaldo Cruz (FIOCRUZ) decidiu implantar uma linha própria de produção e distribuição dos principais medicamentos homeopáticos. A CEME realizou algumas reuniões com representantes de diversas entidades ligadas à homeopatia e à Farmácia Homeopática. A produção e distribuiçăo de medicamentos não foi levada à frente ${ }^{(31,39,44,93,94,95,114)}$. 
O Dr. Gilberto VIEIRA, assessor da presidência da CEME e responsável pelo projeto de Homeopatia naquela instituição, apresentou, durante o XIX Congresso Brasileiro de Homeopatia, o resultado de uma pesquisa, na qual foram enviado 18.000 questionários, perguntando, entre outras coisas, quais os 50 medicamentos e as 3 dinamizações homeopáticas mais utilizadas. A partir das respostas, VIEIRA propôs uma relação com 60 medicamentos, em diferentes dinamizações, que atingiam o total de 100 apresentaçōes. Em um total de apenas 65 respostas, 94\% afirmou que aceitaria prescrever medicamentos homeopáticos clássicos ${ }^{10}$ distribuídos pela CEME e produzidos em laboratórios privados elou oficiais, segundo a Farmacopéia Homeopática Brasileira ${ }^{(129)}$.

Relatório da reunião da CEME de 31 de janeiro de 1989 mostra que efetivamente 60 medicamentos na forma líquida foram escolhidos. Eles seriam distribuidos em caixas com 20 frascos de $20 \mathrm{ml}$. Os medicamentos seriam classificados em 3 diferentes faixas: de grande, de médio e de pequeno consumo. As dinamizaçōes indicadas no questionários como as mais receitadas foram a 30, 6, 200 e 12 centesimais, nesta ordem. Decidiuse fornecer todos os medicamentos apenas na $\mathrm{CH} 30$. O projeto inicialmente destinaria medicamentos gratuitos aos seguintes locais que possuíssem serviço médico homeopático:

- entidades e órgãos oficiais;

- entidades filantrópicas;

- órgãos de classe ${ }^{(20,21,95)}$.

Já no estado de São Paulo, na Secretaria de Estado da Saúde, foi constituído o Grupo Especial de Desenvolvimento do Programa (GEPRO) de Práticas Alternativas de Saúde em fevereiro de 1988. Em maio de 1989 uma Resolução do Secretário da Saúde instituiu a Comissão de Práticas

\footnotetext{
${ }^{9}$ Medicamentos homeopáticos clássicos săo aqui definidos como constituídos por apenas

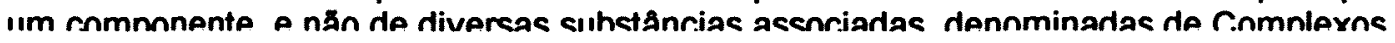


Alternativas de Saúde com a finalidade de preparar subsídios legais para obtenção de produtos de garantida qualidade necessários à implantação das práticas alternativas na rede, uma vez que, naquela época, medicamentos homeopáticos não eram produzidos pelo SUDS-SP. Foram consideradas ainda as dificuldades apontadas nos treinamentos para supervisão em Farmácias e Laboratórios Homeopáticos, Laboratórios Fitoterápicos e Ervanarias. $O$ texto final produzido não foi aproveitado como material legal ${ }^{(115,116)}$.

O Presidente da Comissão Interinstitucional de Saúde do Estado de São Paulo (CIS/SP) aprovou, em 1989, as Diretrizes Gerais para o Atendimento em Homeopatia e o Contrato de Prestação de Serviços de Aviamento de Receitas Homeopáticas. Encontra-se nesta Deliberação a seguinte afirmação:

"Dada a importáncia do medicamento homeopático no atendimento clínico homeopático, torna-se necessário que este seja manipulado com rigor em sua farmacotécnica própria e por profissionais de comprovada especialidade".

Este texto decidia ainda sobre os critérios de contratação de farmácia homeopática a fim de possibilitar a assinatura de um contrato, que deveria ser precedido de licitação na forma da lei ${ }^{(43,117)}$.

\section{Cita MENDICELLI que}

"até julho de 1993, estavam cadastrados nesse grupo de Atendimento em Homeopatia cerca de 100 médicos homeopatas, efetuando atendimento em 60 postos de saúde, gerenciados pelo Estado, na Capital e no interior; esse número não incluía os postos de saúde da Prefeitura de São Paulo, onde a municipalização ainda não havia ocorrido, e que também ofereciam atendimento homeopático. Desde a implantação oficial da Homeopatia nos postos de saúde do Estado de São Paulo, tem sido observado o aumento da clientela 
desse atendimento e o aumento de profissionais da rede pública interessados em atuar nessa especialidade. Entretanto, a crise existente na área da saúde, e demissões voluntárias, têm reduzido o número de médicos na rede estadual. É provável que tenha havido redução no quantitativo de médicos homeopatas, mas não se dispõe de dados atualizados" (91).

MOREIRA NETO afirma que no ano de 1992, 140 médicos homeopatas atendiam nos serviços públicos de saúde do Estado de São Paulo ${ }^{(99)}$.

Segundo informações verbais de vários ex-participantes das coordenadorias anteriormente existentes, os diversos serviços, como o de centralização de dados específicos para Homeopatia, o de fornecimento de medicamentos e locais de concentração de atendimento de profissionais das ditas áreas alternativas, já não existem mais. Alguns locais de atendimento médico homeopático efetivamente foram desativados, porém năo existem mais as informações anteriores que centralizavam estes dados.

Em 1991 foi criado o Departamento de Homeopatia na Associação Paulista de Medicina (APM), em sessão bastante polêmica que contou com palestra do pesquisador francès Jacques BENVENISTE ${ }^{10}$.

A primeira associação estadual de farmacêuticos homeopatas foi a Associação Paulista de Farmacéuticos Homeopatas (APFH), fundada em 9 de julho de 1986. Em 1988 foi criada a Associação Brasileira de Farmacêuticos Homeopatas ( $A B F H$ ), entidade que congrega hoje cerca de 600 associados farmacêuticos. Além da elaboração de 2 edições do Manual de Normas Técnicas (MNT) para Farmácia Homeopática, esta associação

\footnotetext{
${ }^{10}$ Pesquisador francês, diretor de uma unidade de Farmacologia e Imunologia do INSERM, Instituto Nacional de Pesquisas Médicas da França e coordenador de polêmico trabalho publicado na revista Nature. Seu laboratório foi local de estágio curricular durante elaboraçăo desta tese.
} 
criou também, em 1997, o exame de Título de Especialista em Farmácia Homeopática ${ }^{(8,9)}$.

Podemos afirmar com segurança que país algum do mundo conta com número tão grande de farmacêuticos com cursos de especialização em Homeopatia $^{(82)}$.

O Conselho Federal de Farmácia (CFF), através da Resolução 232 de 6 de maio de 1992, e posteriormente das Resoluções 267 (de 9 de fevereiro de 1995) e 335 (de 17 de novembro de 1998), estabeleceu as qualificaçōes para considerar o farmacêutico habilitado para exercer a Responsabilidade Técnica de Farmácia Homeopática ${ }^{(47,48,49)}$.

A AMHB, através de sua Comissão de Saúde Pública, elaborou uma Proposta para Implantação de Atendimento Homeopático na Rede Pública. O objetivo deste documento é orientar os executores das políticas de saúde locais, que desejem implementar um programa de atendimento homeopático no serviço de saúde de sua região, sobre as condições mínimas necessárias para que a prática homeopática possa ser implantada, consolidada e avaliada no SUS, Serviço Único de Saúde. Aponta os recursos humanos e materiais para estabelecimento de uma farmácia de manipulação homeopática própria, embora considere que o medicamento também possa ser fornecido através de credenciamento ou estabelecimento de convênio com farmácias homeopáticas privadas, ou ainda montagem de caixa básica de medicamentos, a critério do médico homeopata local ${ }^{(11)}$.

Dados do V Forum Nacional de Homeopatia na Rede Pública, realizado pela Comissão de Saúde Pública da AMHB, em final de 1998, relataram a existência de 166 homeopatas nos serviços públicos de saúde, sendo 80 no estado do Rio de Janeiro. Não houve informaçőes sobre o estado de São Paulo. Em relação aos 12 mais significativos problemas da Homeopatia na 
rede pública, a dificuldade de acesso à medicação homeopática aparece em $6^{\circ}$ lugar, citada por apenas $6,7 \%$ dos informantes. Ainda que a "Proposta para Implantação de uma Unidade-piloto na Rede Pública do SUS" considere que o paciente deva ter garantia de acesso ao medicamento, $70 \%$ dos serviços enumerados não incluem seu fornecimento. Anexa a esta Proposta, existe uma Relação de 132 medicamentos, assim como um Questionário de Satisfação do Usuário, onde aparecem perguntas sobre a facilidade de encontrar o medicamento e se sua distribuição é gratuita ${ }^{(42)}$.

Apesar das conhecidas dificuldades financeiras e administrativas que enfrentam os serviços de saúde, tanto no Brasil, como em outros países, a Homeopatia tem-se tornado mais popular. A existência de diversos cursos, com número crescente de alunos médicos, farmacêuticos, dentistas e veterinários, assim como a quantidade de farmácias exclusivamente homeopáticas (mais de 100, apenas na cidade de São Paulo, e seguramente mais de 500 no Brasil), atestam o maior interesse da população, que busca este tipo de atendimento médico, tanto nos consultórios privados, como na rede pública.

MENDICELLI, em pesquisa realizada junto a serviços de atendimento médico do Municipio de São Paulo, demostrou que a Homeopatia tem boa aceitação pela população. $O$ atendimento homeopático em posto de saúde foi considerado uma necessidade, sendo a possibilidade de escolha desse tratamento pela população o motivo mais alegado ${ }^{(91)}$.

O Centro de Saúde Escola Geraldo de Paula Souza (CSE-GPS) da Faculdade de Saúde Pública da USP oferece tratamento médico homeopático a sua clientela desde fevereiro de 1995, além de estágio para médico em treinamento, descrito no Informativo da Associação Paulista de Homeopatia como "residência em Homeopatia" e confirmado por MOREIRA NETO ${ }^{(12,14,15,99)}$. 
Em publicação destinada à análise de planos e seguros-saúde privados, o atendimento homeopático está incluído em 9 planos dos 24 considerados, e em um terço dos seguros, sendo que em metade deles encontra-se a observação de ser um atendimento apenas ambulatorial, que não inclui os medicamentos ${ }^{(7)}$.

\section{4 - O medicamento em Homeopatia:}

Uma vez que os medicamentos homeopáticos são preparados principalmente a partir de substâncias vegetais, animais e minerais, infinitesimalmente diluídos em soluçőes hidroalcoólicas, é esperado que haja muita controvérsia sobre sua eficácia e mecanismo de ação. Existem hipóteses para explicar o fenômeno homeopático e modelos para o mecanismo de ação do medicamento dinamizado (103,104,107,111).

Um dos artigos mais conhecidos, que tornou-se um importante marco na história da Homeopatia, foi o de DAVENAS et al. Seu objetivo era demonstrar a ação de soluçōes extremamente diluídas de anticorpos sobre basófilos humanos. Após publicar o artigo com reserva editorial, a revista Nature enviou investigadores ao laboratório de BENVENISTE, para examinar repetiçōes dos experimentos. Apesar dos resultados terem sido confirmados por quatro laboratórios estrangeiros e um outro francês, sua reprodutibilidade era baixa, e repercussōes seguiram-se no mundo todo, tanto em publicaçőes leigas como da parte da comunidade científica internacional, classificando o artigo como uma heresia, e acusando seus autores de insistirem sobre uma fraude ${ }^{(53)}$.

Esse episódio - conhecido como "o caso BENVENISTE" - gerou muita polêmica. Como conseqüência, alguns de seus co-autores acabaram por abandonar pesquisas nesta área, enquanto outros persistem, perseguindo arduamente a comprovação de suas idéias, enfrentando críticas e cortes de 
verbas. Segundo BENVENISTE "os resultados da pesquisa impõem a todos, e sobretudo à comunidade científica, um considerável esforço de adaptação. Trata-se de penetrar em outro mundo conceitual". E ainda:

(...) a obrigação primeira de um cientista é a de constatar experimentalmente a existência de um fenômeno reproduzível e somente depois perguntar-se sobre sua significação e seu mecanismo. Rejeitar resultados estranhos, mesmo que sejam verificáveis experimentalmente (evidentemente apenas ensaios efetuados sob condições experimentais rigorosas por pesquisadores experientes), sob o pretexto de que "não se aceita o que não se compreende", seria uma atitude retrógrada, anticientifica... ${ }^{(28,81)}$.

Todo este caso gerou um interessante livro sobre a liberdade de pensamento na área acadêmica, cujo título em português literalmente é "Um caso de censura na ciência. O caso da memória da água" (113).

Como afirma COULTER, o início dos "testes clínicos controlados", na década de 50, trouxe a idéia de que as barreiras para aceitação da Homeopatia só cairiam caso seu valor terapêutico pudesse ser demonstrado. Uma série de pesquisas clínicas começaram a ser desenvolvidas, podendo ser utilizadas como prova indireta da atividade dos medicamentos, quando comparados a placebos. Algumas mostraram associação positiva no tratamento de diversas patologias, como rinite alérgica, fibrosite e gripe, e outras não mostraram efeito aparente, como o caso de estudos realizados com pacientes de artrite reumatóide e insônia $(37,51,62,65,104,113)$

KLEIJNEN, KNIPSCHILD e RIET, em publicação elaborada com o apoio do Ministério do Bem Estar Social, Saúde Pública e Assuntos Culturais da Holanda, compararam uma série de artigos publicados sobre a clínica homeopática, concluindo que, ainda que a evidência da eficácia da Homeopatia a partir das pesquisas clínicas tenha sido positiva, é necessário 
maior rigor metodológico na maior parte destas pesquisas, para chegar-se a conclusões definitivas ${ }^{(79)}$.

A técnica de preparo de medicamentos homeopáticos foi estabelecida por HAHNEMANN há 200 anos. Tendo vivido até os 88 anos, HAHNEMANN foi experimentando novas propostas clínicas, conjugadas com modificaçōes no preparo dos medicamentos. Vários discípulos difundiram a Homeopatia pelo mundo, sem conhecer a 6 edição do Organon, publicada mais de 100 anos após sua morte ${ }^{(0)}$.

Também nas Farmacopéias encontramos alterações nos métodos e nas substâncias estabelecidas por HAHNEMANN. Poucos países possuem Farmacopéias Homeopáticas Oficiais: França, Estados Unidos, Alemanha, Inglaterra, Chile, Índia, México e Brasil. O fato de estarmos entre os países que possuem Farmacopéia, mostra o desenvolvimento desta terapêutica entre nós e torna o medicamento oficial no país, porém isto não significa que o medicamento seja padronizado. Percebe-se muitas diferenças, e até mesmo contradições, entre as várias técnicas de preparo, ainda que todas sejam legais, isto é, amparadas por Farmacopéias Oficiais. BARTHEL e também DELLMOUR, dedicam-se a salientar modificações das práticas encontradas nos textos originais, que vão, por exemplo, desde o uso de espécie vegetal diferente, como é o caso da substituição da Bryonia alba pela Bryonia dioica, passando pelo uso da abelha inteira e não mais apenas seu veneno, a não-trituração de vegetais e substâncias solúveis (como HAHNEMANN propôs no final de sua vida), até o uso de grandes quantidades na trituração - o que leva a uma menor eficácia da técnica e perda do potência do medicamento. Medicamentos obtidos através de diferentes métodos de preparo são comparados, indicados ou contraindicados, sem que estes métodos sejam plenamente conhecidos e criticados. A padronização e normatização do próprio atendimento médico homeopático passa pelo conhecimento e normatização do medicamento, 
importante instrumento desta terapêutica. Um dos comentários de ADLER et al. é que a pesquisa clínica poderia obter beneficios substanciais, possibilitando a comparação dos resultados clínicos, caso ocorresse a padronização farmacêutica ${ }^{(4,22,23,24,54,61,67,72,73,98,102,105,125)}$.

COULTER afirmou que cada substância usada na prática homeopática tem sua característica individual, similiar a nenhuma outra, não podendo portanto ser substituída. Esta idéia conduz à possibilidade de uso de um número ilimitado de substâncias, sendo a limitação o conhecimento do homeopata, que, quando unicista ${ }^{11}$, procura chegar à exata substância medicamentosa necessária ao quadro individualizado dos sintomas de cada paciente. Uma relação de 2000 medicamentos definem ainda mais de 2000 estados patológicos (conjunto de sintomas) diferentes, uma vez que um paciente manifesta apenas uma parte dos sintomas de cada medicamento. Percebe-se claramente a importância do conhecimento claro e detalhado dos sintomas provocados pelas substâncias no homem são, isto é, sua patogenesia, conhecida através de sua "experimentação ${ }^{1211}(51,52,77)$.

Afirma-se que os unicistas buscam o tratamento individualizado da totalidade do doente. Através de uma única substância, comparando os sintomas que ela provoca em indivíduos saudáveis e aqueles do doente a ser tratado, procuram curar a patologia do seu paciente. Já os homeopatas

\footnotetext{
${ }^{11}$ Classificam-se tradicionalmente as escolas médicas homeopáticas em Unicistas, quando seus seguidores prescrevem apenas um medicamento, em dose única ou repetida; Pluralista, quando prescrevem vários medicamentos; Complexistas, quando prescrevem vários medicamentos preparados em uma só formulaçåo ou ainda Alternistas, quando altemam estes diversos medicamentos. Podemos considerar ainda a divisăo entre os médicos que prescrevem baixas potências e altas potências, estes últimos influenciados principalmente por KENT. Além da fundamentaçăo teórica das diferentes escolas variar em relaçăo à idéia básica de Hahnemann, temos uma consequência direta na prescriçăo do medicamento, que pode ser único (única substância, em dose única ou repetida), diversos alternados, ou diversas substâncias preparadas em conjunto ${ }^{(17,52)}$.

${ }^{12}$ Experimentaçăo é o processo sistemático de testar substâncias em indivíduos saudáveis para elucidar sintomas, que permite obter a descrição de sintomas de novos medicamentos, assim como a confirmar sintomas já descritos nas Matérias Médicas homeopáticas.
} 
pluralistas utilizam diversas substâncias, administradas juntas em uma formulação (complexo), ou de forma alternada, geralmente em potências ${ }^{13}$ mais baixas. Seu objetivo é encontrar medicamentos para quadros de sintomas, isto é, para doenças, ainda que individualizem a forma como determinada doença se manifesta em diferentes individuos. Uma vez que existe um número relativamente restrito de categorias de doenças, os pluralistas prescrevem, em geral, um número menor de substâncias. Este é o fundamento para os complexos, ou também chamados "específicos homeopáticos" ${ }^{(52,101)}$.

As divergências entre unicistas e pluralistas/alternistas/complexistas têm levado a separaçōes entre os homeopatas. HERING, introdutor da Homeopatia nos Estados Unidos, afirmou: "Se nossa escola abrir mão do estrito método indutivo de HAHNEMANN, estaremos perdidos, e mereceremos ser mencionados apenas como uma caricatura na história da medicina" (52).

A Homeopatia permanece sendo aplicada de maneira individualizada, o que embora seja de grande valor no atendimento médico sob a ótica da Saúde Pública, tem alcance populacional restrito. Em oposição, a Alopatia testa substâncias até encontrar a relação ótima entre dose e freqüência de administração, que sejam aplicáveis, na média, à maior parcela da população.

Lidando com pequenos números, a Homeopatia não conseguiu manter o mesmo desenvolvimento do conhecimento especifico da substância de origem para o preparo dos medicamentos obtido pela Alopatia. Assim, por exemplo, não utilizar a planta originalmente descrita mas sim uma similar,

\footnotetext{
${ }^{13}$ A potência do medicamento homeopático indica quantas vezes ele foi dinamizado, isto é, diluído e agitado.
} 
deve muito mais ser creditado às dificuldades para localizar a primeira, do que às vantagens auferidas com a segunda.

O processo de evolução tecnológica passa pelas dificuldades de se fazer ou utilizar o tradicional. É esta dificuldade que impulsiona a busca de uma nova alternativa. Quando lidamos com grandezas mensuráveis, podemos avaliar se a experiência conduziu a um ganho ou a uma perda na eficiência do processo. Entretanto, apenas clinicamente podemos ensaiar se 0 medicamento homeopático obtido com uma planta similar, por exemplo, conduz aos mesmos resultados daquele obtido a partir de uma original.

Se a Matéria Médica relaciona substâncias a sintomas por elas desenvolvidos em indivíduos saudáveis, certamente variações nessas substâncias só deveriam ser validadas após a inserção de modificações nestas obras, importante fonte de consulta dos clínicos homeopatas.

Ainda são poucos os que atentam para estes detalhes, mas a continuar o crescimento que a Homeopatia tem experimentado como alternativa de tratamento, maior será a exigência de um medicamento mais homogêneo, mais padronizado e de melhor qualidade, nos próximos anos. Um produto de qualidade é aquele que atende perfeitamente, de forma confiável, acessivel, segura e no tempo certo, às necessidades do paciente. Hoje o consumidor, final ou intermediário, está mais atento e exigente ${ }^{(36)}$.

A unificação do Mercado Comum Europeu exigiu revisão nas legislações de cada país-membro participante, com a elaboração, em 1992, da Diretiva $92 / 73 / E E C$, destinada a harmonizar as regulamentaçōes dos produtos medicinais homeopáticos para uso humano. Descreve o escopo, manufatura, controle e inspeção, normas para colocação no mercado e provisões finais. Os países membros da União Européia que não tiverem uma proposta nacional para registro dos medicamentos, devem aceitar em 
seu mercado medicamentos registrados em outros estados membros ${ }^{(46,77,80)}$.

A Diretiva reconhece a natureza especial do medicamento homeopático e permite um sistema simplificado de registro, baseado apenas na qualidade e na segurança, desde que os medicamentos sejam:

- apenas para uso oral ou externo

- suficientemente diluídos para garantir segurança, geralmente a 1:10.000 ou seja, a partir de D4 ou $2 \mathrm{CH}$;

- comercializados sem declaração de eficácia ou terapêutica ${ }^{(46)}$.

Produtos mais concentrados, ou injetáveis, devem responder aos mesmos critérios dos medicamentos convencionais alopáticos, como procedimentos de Controle de Qualidade, testes de estabilidade e dados sobre a segurança $^{(46,7)}$.

Existe no Reino Unido outro sistema de licença ("Special Manufacturing Licence" ou seja, Licença Especial de Fabricação), que permite que farmácias forneçam medicamentos tanto para o público, quanto para hospitais, clinicos e outras farmácias que não possam fazê-los. Não é proposto para a produção de medicamentos em grande escala, com formação de estoques. Estes estabelecimentos são inspecionados regularmente e devem ter registro de seu fornecimento e de seus procedimentos de Controle de Qualidade ${ }^{(7)}$.

Em relação a questōes de registro, na União Européia, de modo geral, o medicamento homeopático clássico tem uma situação semelhante à dos outros, também submetidos à Autorização para Venda, embora não necessite provar sua eficácia. Na França, 1163 medicamentos homeopáticos tem $65 \%$ do seu valor reembolsável pela Previdência Social, taxa em principio reservada aos produtos que tiveram sua eficácia provada 
para afecções de uma certa gravidade. Não requerem prescrição para venda, assim como nos Estados Unidos são de venda livre desde 1938, embora estejam submetidos ao controle do órgão controlador de medicamentos e alimentos, o FDA ${ }^{(1)}$.

Steven KAYNE, em palestra proferida em janeiro de 1999, durante o Seminário Internacional sobre Assistência Farmacêutica, promovido pelo Conselho Regional de Farmácia (CRF) do Estado de São Paulo, em janeiro deste ano, afirmou que cerca de $80 \%$ do total dos medicamentos, inclusive os homeopáticos, prescritos por clínicos no Reino Unido, são gratuitos. Medicamentos prescritos pelo Serviço Nacional de Saúde ("National Health Service" ou NHS) é totalmente reembolsado, porém o paciente deve arcar com uma taxa fixa de imposto, que pode exceder o valor do medicamento, especialmente do homeopático, que é barato. Neste caso, é menos oneroso que o cliente adquira o medicamento homeopático como "de venda livre", também conhecido como OTC ("over the counter") (77).

Na América Latina, com a criação do MERCOSUL, os paises associados vêem-se obrigados igualmente a unificar suas normas, entre elas as relacionados à fabricação de medicamentos. Um dos primeiros reflexos dessas novas exigências é a pressão que passou a exercer o Ministério da Saúde, através da Secretaria de Vigilância Sanitária, para que as indústrias farmacêuticas em geral, e as homeopáticas em particular, adaptassem-se às normas internacionais de $\mathrm{GMP}^{14}$.

Em São Paulo, um grupo de farmacêuticos de laboratórios industriais farmacêuticos elaborou e encaminhou ao Ministério da Saúde normas de GMP específicas para esta área, que tem características diferentes daquelas da indústria farmacêutica alopática. É importante que técnicos tenham a iniciativa de propor sugestőes e medidas especificas relativas a

\footnotetext{
${ }^{14}$ GMP, Good Manufacture Practices, ou seja, Boas Práticas de Fabricaçăo (BPF): conjunto de normas internacionais a serem sequidas bara obtencăo de medicamentos de aualidade.
} 
pontos onde existam diferenças nas condutas industriais farmacêuticas, visando uma adequação à realidade atual, e um preparo para o futuro desenvolvimento da industrialização de medicamentos homeopáticos. A normatização ainda incompleta na área homeopática permite que a produção industrial coloque no mercado medicamentos sem especificações, de baixa padronização e conseqüente baixa qualidade. Apesar de suas particularidades, o produto homeopático deve ser tratado igualmente como medicamento. Isto significa buscar inibir a atuação de laboratórios não habilitados, ou a prática comum de agregar o termo "produto homeopático" a medicamentos de baixa qualidade, freqüentemente veiculados pela mídia, adquiridos através de correio, que, com esta qualificação, buscam acobertar-se em exigências menores ${ }^{(120)}$.

A Secretaria de Vigilância Sanitária do Ministério da Saúde, através da Portaria n 2.543 de 14 de dezembro de 1995, instituiu o Grupo Assessor Técnico-Científico em Medicinas Não-Convencionais (GATC-MnC), com a finalidade de contribuir para normatizaçăo dos serviços, bem como para o estabelecimento de padrões de qualidade de substâncias e produtos nas medicinas näo convencionais, com vistas ao seu controle. Além de prestar assessoria, este Grupo deveria cooperar tecnicamente para adoção e implementação de medidas que garantissem a qualidade e possibilitassem o acesso seguro aos serviços das medicinas năo convencionais no SUS. Outra função era colaborar na divulgação de informaçōes e na formação e capacitação de recursos humanos para a Vigilância Sanitária e outros setores da rede de serviços do SUS, na área das medicinas não convencionais. Na reunião inicial, em março de 1996, foram organizadas 4 subcomissões a saber: Acupuntura, Fitoterapia/Ayurvédica, Antroposofia e Homeopatia. Estas reuniōes não seguiram adiante. Hoje, a estrutura desta Secretaria sofreu profundas alteraçōes, com a criação da Agência Nacional de Vigilância Sanitária (ANVS) ${ }^{(97,106)}$. 
U desenvolvımento da Homeopatia em nosso pais coıncidıu com o retorno do farmacêutico à farmácia pública. No início dos anos 80 , começaram a surgir novas farmácias de manipulação voltadas para o preparo de medicamentos homeopáticos. Neste novo espaço, abria-se um dos âmbitos de atuação para o farmacêutico, profissional que havia deixado o comércio de medicamentos, mais recentemente realizado principalmente em drogarias, estabelecimentos que apenas os comercializam.

O crescimento rápido do número de farmácias homeopáticas, se por um lado trouxe vantagens para a população, que passou a ser atendida por farmacêuticos, por outro instalou um grande número de estabelecimentos que atuam como pequenas "unidades de fabricação", que lidam com mais de 2000 substâncias, cada uma com uma infinidade de potências, combinaçōes de substâncias e formas farmacêuticas diversas, reforçando e realçando a pouca padronização em seus procedimentos.

As associações de farmacêuticos homeopatas começaram a ser formadas no final da década passada, inicialmente no Estado de São Paulo (APFH), e depois em outros estados, chegando até a fundação da Associação Brasileira de Farmacêuticos Homeopatas, que elaborou o Manual de Normas Técnicas (MNT), já em sua 2a. edição. Estes Manuais foram escritos a partir de Encontros Nacionais de Farmacêuticos Homeopatas. Existia, na época, uma $1^{\star}$ edição da Farmacopéia Homeopática Brasileira que continha pontos diferentes de todas as outras Farmacopéias de outros países, e era pouco seguida pelos farmacêuticos em suas farmácias. 0 Manual foi elaborado segundo discussōes que ocorreram entre as centenas de farmacêuticos presentes durante os diversos Encontros Nacionais de Farmacêuticos Homeopatas. Mesmo contando com a democrática participação dos interessados, suas recomendaçōes não foram prontamente seguidas. Em continuidade deste trabalho, em novembro de 1997, foi publicada a 2a. edição da Farmacopéia Homeopática Brasileira. Diferente 
da dinâmica do Manual, esta foi elaborada por uma pequena comissão composta de 5 farmacêuticos e suscitou diversas manifestações ${ }^{(7,8,9,16,60)}$

Até que regulamentações amplamente acatadas pela totalidade dos farmacêuticos sejam efetivamente implantadas em todo o país, permanecerá entre nós uma realidade de medicamentos nem sempre padronizados, que permite até que produtos diferentes, obtidos a partir de diversos métodos, sejam dispensados com o mesmo nome. Mesmo que tal fato seja parcialmente conhecido pelo médico, é, via de regra, considerado irrelevante, ainda que o medicamento seja instrumento valioso para o tratamento que este profissional prescreve ${ }^{(123)}$.

Em outros países, como na França e Alemanha, este preparo ocorre em grandes indústrias, sob uma rígida padronização determinada por Farmacopéias bem estruturadas. Por exemplo, a parte homeopática da Farmacopéia Francesa foi introduzida em 1965, e hoje contém também normas de controle, fabricação e registro de medicamentos homeopáticos. A Farmacopéia Homeopática Alemã prima pelos métodos de Controle de Qualidade que inclui nas monografias das substâncias que dão origem ao medicamento homeopático. As grandes indústrias francesas procuram estender este modelo para outros paises, como os do Leste Europeu e Estados Unidos. Por diversas razōes, inclusive provavelmente devido à instabilidade econômica comum nas últimas décadas em nosso país, o modelo de preparo de medicamentos homeopáticos produzidos pelas indústrias farmacêuticas homeopáticas multinacionais não foi implantado aqui, desenvolvendo-se, pelo contrário, as muitas farmácias homeopáticas, cada uma atuando como uma "pequena indústria farmacêutica" ${ }^{72,73,102)}$.

A Argentina, de onde vieram ao Brasil diversos professores médicos, além do farmacêutico Arturo MENDEZ, que ensinou durante muitos anos em Curitiba e São Paulo, também enfrenta hoje a necessidade de padronizar as 
técnicas de preparo dos medicamentos homeopáticos. Durante a II Jornada Farmacêutica da Associação Médica Homeopática Argentina, em 1997, houve o questionamento sobre quais os melhores caminhos a serem seguidos, uma vez que o país não contava com Farmacopéia Homeopática: seria melhor adotar uma Farmacopéia já existente? Ou seguir a experiência que ocorreu no Brasil, com a elaboração de um Manual dinâmico que incentivou o trabalho de um grande número de participantes, mobilizando profissionais para agir em resposta às suas necessidades? Evidenciou-se a necessidade de iniciarem-se discussões para a elaboraçăo de textos preliminares, para serem aprimorados no futuro ${ }^{(90)}$.

Outro ponto a ser notado é que não se pode analisar o medicamento homeopático da mesma forma que os alopáticos. Este fato introduz outra dificuldade, já que apenas as baixas potências podem ser rotineiramente testadas. Assim sendo, a qualidade do medicamento diluído depende de um rígido controle sobre as matérias primas iniciais, bem como dos solventes e veículos. Depende ainda de um seguimento rigoroso dos procedimentos técnicos utilizados durante $\circ$ preparo. Testes para medicamentos dinamizados (e geralmente bastante diluídos), são ainda tentativas sofisticadas e caras, incompativeis com o Controle de Qualidade cotidiano. Isto pode inserir um fator altamente subjetivo na escolha da farmácia ou indústria que os fornece, ou ainda favorecer critérios como o de menor custo, com prejuízo de qualidade adequada ${ }^{(m)}$.

Considerando que o medicamento deva ter caráter universal, especialmente para o atendimento no serviço público, quando focamos a Homeopatia, podemos acrescentar à diversidade de medicamentos, a orientaçăo terapêutica das diversas escolas homeopáticas, que privilegiam potências, escalas e até grupos de medicamentos, o que torna difícil a adequação de quais necessidades suprir para atendimento da população. 
Além disso, deve-se levar em conta que:

- a Homeopatia é um recurso importante para questões de Saúde Pública, já ocupando um lugar no sistema de saúde;

- o medicamento é importante no tratamento homeopático, tendo características diferentes e dificuldades para ser padronizado. É o insumo crítico para 0 atendimento médico homeopático da população.

Algumas questões impōem-se: como pode ser tratada a questão "medicamento" nos programas onde há atendimento homeopático em serviços públicos de saúde? Em que medida pode-se fornecer subsídios para políticas relativas ao medicamento, que torne a Homeopatia mais instrumentalizada, mais sólida e consistente?

O medicamento, ainda que seja um insumo variável, tem que dar consistência ao modelo de assistência médica homeopática à saúde, sendo importante preservar a implantação da Homeopatia, devido a problemas com seu fornecimento. $\mathrm{O}$ abastecimento não deve depender de doações ou soluções alternativas a serem encontradas em cada local que deseje implantar o serviço de atendimento homeopático.

O estudo visa, em resumo, analisar este insumo crítico - o medicamento em todas suas características-problemas, para diminuir as dificuldades, oferecendo subsídios para normatizar e para implementar políticas de medicamentos que possam beneficiar o atendimento médico homeopático no serviço público de saúde. 


\section{2 - OBJETIVOS DO TRABALHO:}

Foram estabelecidos os seguintes objetivos para esta tese:

- estudar e descrever experiências de fornecimento de medicamento em serviços de saúde;

- oferecer subsídios para formulação de políticas de medicamentos homeopáticos para os serviços públicos de saúde, contornando possiveis dificuldades que possam prejudicar a implantação ou a manutenção do atendimento médico homeopático nestes serviços.

- fornecer elementos para incrementar a implantação da Homeopatia, por meio de propostas para o medicamento, que tornem mais fácil e possivel o desenvolvimento dos programas; 


\section{3 - METODOLOGIA:}

Com o objetivo de conhecer como ocorre o fornecimento do medicamento homeopático em serviços médicos, foi iniciada uma busca de informaçōes dos locais que ofereciam esta alternativa terapêutica.

Em um primeiro momento, com a finalidade de ampliar os conhecimentos, visando também o desenvolvimento dos instrumentos metodológicos, foi realizada, em 1996, uma visita ao Centro de Saúde Escola - Geraldo de Paula Souza (CSE-GPS), da Faculdade de Saúde Pública da Universidade de Săo Paulo. As informaçōes obtidas nessa entrevista com o diretor do serviço serviram como uma amostra intencional para indicação de como estava ocorrendo o atendimento na área de Homeopatia, tanto do ponto de vista médico, quanto em relação ao fornecimento dos medicamentos. Como instrumento básico foi utilizado um roteiro de perguntas, que pode ser observado no Anexo 1.

Este roteiro posteriormente foi utilizado no estudo dos outros serviços, na parte das questões que eram concernentes.

Utilizando as segundas vias das prescrições obtidas em uma farmácia conveniada, que fornecia os medicamentos prescritos durante 0 atendimento médico realizado no CSE-GPS, relacionou-se os pacientes, segundo o nome e todos os dados disponiveis nas receitas. Em seguida, estudou-se os medicamentos homeopáticos mais receitados, suas potências, formas farmacèuticas e posologia. Os resultados deste estudo piloto foram comparados com os de outro, referente a prescrições médicas aviadas pela mesma farmácia conveniada, porém 10 anos antes ${ }^{(40)}$.

A partir deste estudo piloto, decidiu-se visitar um número maior de serviços, para verificar se esta tendência se mantinha e ou, eventualmente, quais 
outras surgiriam.

A escolha dos locais foi intencional e deu-se por conhecimento da existência de serviços médicos homeopáticos, por sua qualidade e pela possibilidade de visita ou obtenção das informações através de telefone, fax e correio. Parecia importante que os serviços diferissem em suas características, possibilidade e observação de diferentes aspectos e realidades.

Foram buscadas tanto informaçōes sobre o serviço, quanto aquelas relativas ao receituário prescrito.

O estudo dos locais escolhidos deu-se através de formulários aplicados durante entrevista aos responsáveis pelo serviço de atendimento nos locais, quando possivel, além de coleta de dados nas unidades onde eles eram disponiveis. A análise de cópias de receituário médico, de anotações das farmácias, de Livros de Registro de Receituário e de informações coletadas em fichas clínicas, forneceu as informações relativas aos medicamentos prescritos, que dependeram das características do serviço. Em alguns casos as informaçōes foram detalhadas; em outros, restritas, mas mesmo assim mantidas no texto por oferecerem um aspecto diverso ou por confirmar outro já descrito em diferente serviço.

Os locais estudados foram:

1. Centro de Saúde-Escola "Geraldo Paula Souza", da Faculdade de Saúde Pública da USP, que atende em área central da cidade de São Paulo.

2. Centro de Terapia Alternativa do Posto de Saúde Municipal "Agostinho Neto" no Municipio de Itú, localizado a aproximadamente $100 \mathrm{~km}$ da cidade de São Paulo, com uma população de cerca de 150.000 habitantes. 
3. Policlínica de Brumadinho, Município da Grande Belo Horizonte, MG, localizado a $65 \mathrm{~km}$ da capital, com população de cerca de 25.000 habitantes.

4. Centro de Saúde de Santo Amaro da Imperatriz, Municipio que dista $35 \mathrm{~km}$ de Florianópolis, SC, com população de cerca de 15.000 habitantes.

5. Ambulatório Médico Homeopático Hahnemanniano da Instituição Alan Kardec - Alice Pereira (IAKAP): instituiçăo filantrópica com atendimento médico homeopático, situado na periferia do Município de Guarulhos, na Grande São Paulo.

6. Ambulatório Municipal de Homeopatia em Campinas, cidade de quase 1.000 .000 de habitantes, localizada a $100 \mathrm{~km}$ de São Paulo.

7. Programa de Fitoterapia e Homeopatia da Prefeitura Municipal de Ribeirão Preto, Município de $\mathbf{5 0 0 . 0 0 0}$ habitantes, localizado cerca de $320 \mathrm{~km}$ da cidade de São Paulo.

8. Dourados, em Mato Grosso do Sul. Cidade de cerca de 160.000 habitantes, localizada a $224 \mathrm{~km}$. de Campo Grande.

9. Associação Paulista de Homeopatia (APH): atendimento ambulatorial de Instituição de Ensino de Homeopatia, na cidade de São Paulo.

Da mesma forma nestes serviços foram relacionados os dados das prescriçōes, quando disponiveis, e analisadas a freqüência dos medicamentos homeopáticos e sua forma de apresentação.

As informaçōes e caracterização dos diversos serviços pode ser vista no QUADRO 1, na próxima página. 
QUADRO 1: caracterização do método utilizado no estudo dos locais de atendimento médico homeopático ou de aviamento de receituário homeopático.

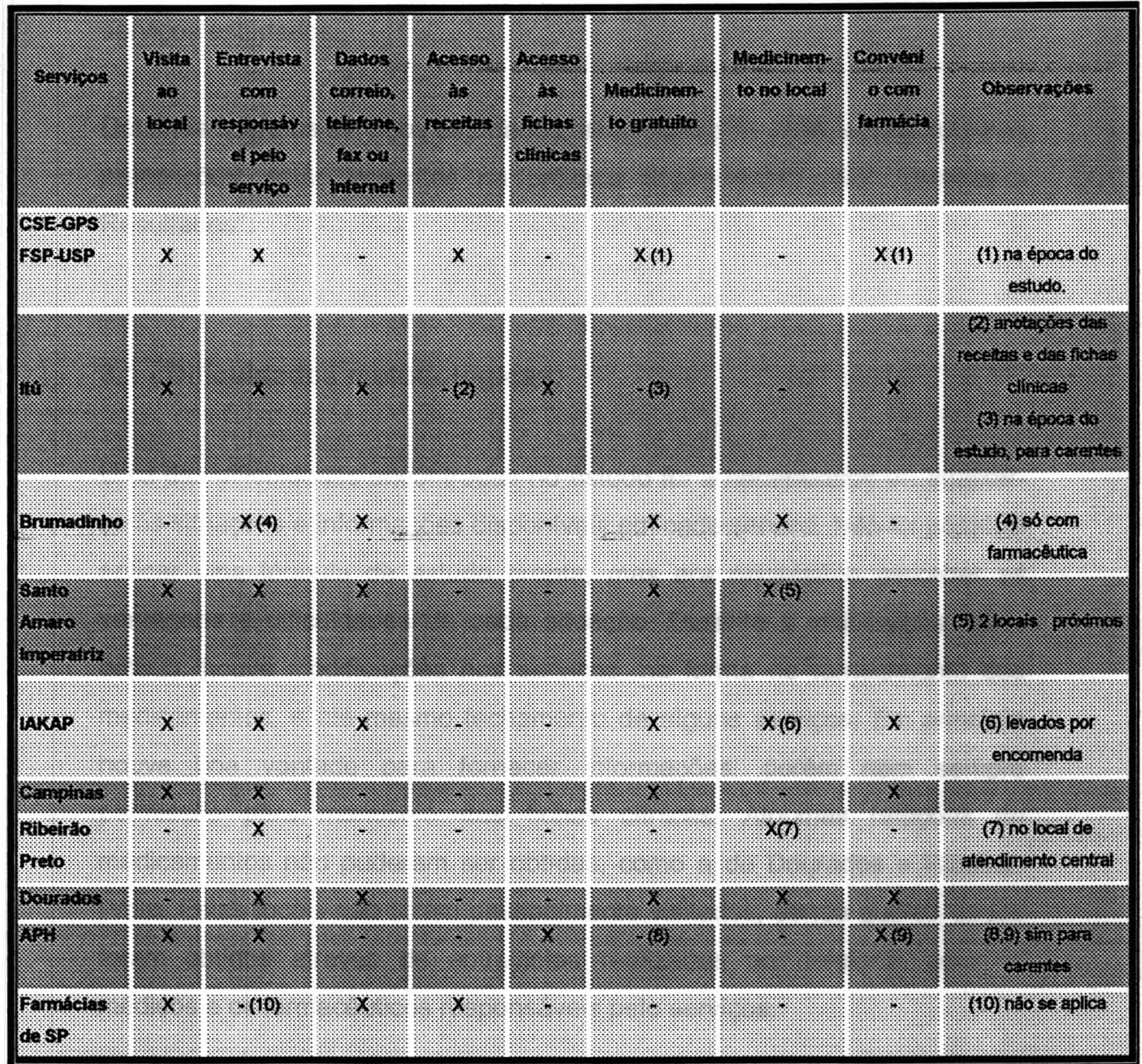

$\mathrm{X}$ significa resposta afirmativa

Percebe-se que os serviços apresentavam características diferentes. Em alguns existia fornecimento gratuito de medicamento, seja no próprio local de atendimento médico ou em farmácia próxima conveniada.

Conforme feito anteriormente durante o estudo piloto, decidiu-se estudar 
também uma amostra de prescrições aviadas em farmácias homeopáticas da cidade de São Paulo, comparando-a com os resultados obtidos nos serviços estudados.

Detalhes sobre os serviços estudados, assim como as informaçōes sobre as prescrições, estão descritos na próxima seção desta tese: "Análise e Resultados".

\section{1 - Dificuldades metodológicas:}

Uma das dificuldades encontradas no estudo foi a necessidade de adaptarse às situações e informações disponíveis em cada serviço. Não foi possível aplicar uma fórmula de estudo pronta, mas era necessário perceber as vantagens e dificuldades de cada situação. Durante a elaboração deste estudo, houve modificações nos serviços, na forma de fornecimento dos medicamentos, e até mesmo fechamento de alguns serviços. Em princípio houve boa vontade para fornecer informaçōes, porém nem sempre permissão para manuseio das fichas clínicas. Algumas relações de medicamentos não puderam ser obtidas, como a de Dourados e Ribeirão Preto. Estes locais não foram pessoalmente visitados, sendo que os dados foram obtidos através de entrevistas realizadas por telefone, com os médicos e os farmacêuticos responsáveis pelo serviços.

Os medicamentos prescritos pelo Ambulatório Municipal de Homeopatia de Campinas eram fornecidos por farmácia pública da cidade, que não possuía anotação à parte dos aviamentos feitos para aquela instituição. Seria necessário separar, na própria farmácia, as prescrições manipuladas para a Policlínica, de todas as outras, a partir do Livro de Registro de Receituário.

Alguns serviços possuíam informações mais organizadas, mas a maioria 
simplesmente contava com um conjunto de fichas e cadernos, nunca ou pouco analisados, ou tratava-se até mesmo de um serviço de atendimento clínico praticamente sem registro de informações. Estas impressões emergiram em situaçőes de visita, o que pode ter dificultado o acesso.

O manuseio das fichas clínicas revelou pouca organização no seu preenchimento. Freqüentemente não havia registro do medicamento indicado, ou seu nome aparecia escrito de forma ilegivel ou incompleto. Nem sempre o medicamento era destacado na história clínica. A falta de legibilidade e de dados completos do medicamento prescrito repetiu-se nas prescrições estudadas. Com muita freqüência havia apenas o nome do medicamento e sua potência, mas não a forma farmacêutica e a dose, fazendo supor que eram escritos na receita, porém não transcritos para a ficha clínica. 


\section{4 - ANÁLISES:}

\section{1 - Características do Centro de Saúde Escola Geraldo Paula Souza (CSE-GPS): a visita-amostra}

Nesta visita-amostra, foi feita uma entrevista com o médico sanitarista diretor técnico do Centro de Saúde, na presença de farmacêutica responsável pelo atendimento dos medicamentos, sendo possivel obter uma visão geral sobre o Centro de Saúde e de como está se desenvolvendo o atendimento em Homeopatia. Estas informaçōes foram complementadas com análises extremamente úteis de MOREIRA NETO(91,113)

Este Centro de Saúde foi o primeiro a ser fundado na América Latina. Atende a uma região com população de 187.000 residentes. Seus matriculados são provenientes de duas categorias: residentes e trabalhadores da área, além de funcionários, professores, alunos, dependentes e agregados da Faculdade de Saúde Pública. Oferece os programas de Saúde da Mulher, da Criança, do Adulto, dos Adolescentes e Idosos; os serviços de Tuberculose, Hanseníase, Doenças Sexualmente Transmissíveis (DST), Odontologia, Saúde Mental, Oftalmologia e Fonoaudiologia. Tem os seguintes serviços de apoio: Laboratório de Análises Clínicas, Farmácia, Radiologia, Serviço Social, Recepção e Agendamento.

A clientela principal é composta por crianças até os 9 anos de idade $(30,8 \%)$ e $66 \%$ dela é do sexo feminino, o que, segundo MOREIRA NETO é observado por outros autores sobre 0 atendimento em serviços públicos de saúde da zona urbana do Município de São Paulo ${ }^{(99)}$.

Como apoio ao ensino, conta com estagiários de Psicologia, 
Fonoaudiologia, Nutrição, Enfermagem e Medicina.

A farmácia do Centro de Saúde atende às prescrições médicas com medicamentos fornecidos pela Central de Medicamentos (CEME), Fundação para o Remédio Popular (FURP) e alguns adquiridos diretamente a partir de laboratórios e distribuidoras.

Na época da entrevista, em 1996, o serviço médico homeopático já existia há cerca de um ano. Seus objetivos eram o atendimento de pacientes, a pesquisa e o ensino. Contava com 2 médicos homeopatas que atendiam, cada um deles, durante 3 períodos de 4 horas (ou seja, 12 horas por semana), e um médico estagiário ou residente. Em cada período eram atendidos 2 casos novos e 4 retornos. Haviam passado pelo serviço de Homeopatia cerca de 200 pacientes.

No segundo semestre de 1995 foram realizadas 458 consultas homeopáticas. A média de atendimento é de 3 consultas por período de 4 horas ${ }^{(9)}$.

O encaminhamento dos pacientes ocorria a partir de funcionários do Centro de Saúde e da Faculdade de Saúde Pública (54\%), de outros serviços (36\%) e também de forma espontânea (10\%). A queixa principal eram problemas respiratórios $(33 \%)^{(99)}$.

Para solucionar o fornecimento de medicamentos homeopáticos foi feito um convênio informal com farmácia homeopática, próxima ao Centro de Saúde ${ }^{15}$. A prescrição era feita em duas vias. Através deste convênio, 0 paciente atendido no Centro de Saúde ia até a farmácia e recebia o medicamento gratuitamente, acompanhado da primeira via da receita. Ao

\footnotetext{
${ }^{15}$ Farmácia Homeopática HN-Cristiano, situada a 7 quadras do Centro de Saúde.
} 
final do mês a farmácia enviava ao Centro de Saúde as segundas vias das receitas atendidas, sendo ressarcida por elas. Apenas os medicamentos homeopáticos eram fornecidos gratuitamente aos pacientes, porém não as essências florais ou minerais (Medicina Ortomolecular) eventualmente prescritos durante $\mathrm{o}$ atendimento médico.

Este convênio era considerado satisfatório para o Centro de Saúde, uma vez que o volume de medicamentos era relativamente pequeno, e os recursos suficientes para a compra, além de existir farmácia homeopática próxima. Estava, porém nos planos do Centro de Saúde, a montagem de uma farmácia no local, para manipulação dos medicamentos homeopáticos. Apesar de não haver uma farmácia de manipulação de medicamentos alopáticos, os motivos apresentados para a montagem da farmácia homeopática foi porque estes últimos medicamentos não apresentam a mesma estrutura de medicamentos industrializados. Em 1998 o convênio foi cancelado por parte do Centro de Saúde, por falta de verbas, e os pacientes passaram a não mais receber os medicamentos gratuitamente, porém apenas um desconto. Mesmo tendo que pagar pelos medicamentos, o médico consultante do serviço, afirmou, em contato pessoal, que os pacientes continuavam procurando pelo atendimento médico homeopático. Da mesma forma, pacientes de um serviço extinto do bairro do Tucuruvi, dirigiam-se para consultas ao CSE-GPS, retirando o medicamento, também com desconto, em outra unidade da mesma farmácia, localizada no bairro de Santana.

Ainda na entrevista inicial, discutiu-se igualmente se as exigências para a montagem de uma farmácia homeopática adequada não superariam em muito a demanda gerada unicamente pelo Centro de Saúde, criando ociosidade. Cogitou-se que o ideal seria que esta farmácia fosse articulada com a Secretaria de Estado da Saúde, para possivelmente fornecer medicamentos para vários Centros de Saúde. 
Um ponto a considerar é que, mesmo recebendo gratuitamente os medicamentos, em função das grandes distâncias e as dificuldades com trânsito, que existem na cidade de São Paulo, a ida até uma determinada farmácia central poderia implicar para os pacientes em gastos com 0 transporte, além do tempo despendido. Estes fatores podem fazer com que alguns pacientes paguem pelos medicamentos, comprando-os perto de sua casa ou local de trabalho.

Nessa ocasião foi lembrada a experiência do NAPTA (Núcleo de Atendimento e Pesquisa em Terapias Alternativas), do Centro de Saúde no Belenzinho, na Zona Leste da cidade, que já teve atendimento homeopático com oito médicos, dois acupunturistas, uma farmacêutica e farmácia homeopática no local. Informaçōes obtidas por telefone indicaram que este serviço está hoje praticamente desativado, atendendo no local apenas um homeopata, três manhãs por semana.

Sobre a compra antecipada de medicamentos homeopáticos pelo Centro de Saúde, a resposta foi de que sendo o volume total pequeno, com grande número de itens, haveria dificuldades para um bom planejamento das compras, e o resultado seria a formação de grandes estoques, gerando prejuizos.

Uma vez que o custo para o aviamento da receita é associada à forma de prescrição do clínico, caso outros médicos - que prescrevessem de forma pluralista ou complexista, gerando portanto prescriçōes mais caras viessem a atender no Centro de Saúde, poderia não ser possível continuar com o sistema de fornecimento, por falta de verbas. Caso, em vez de convênio, o Centro de Saúde contasse com estoque pré-existente de medicamentos, este poderia mostrar-se completamente inútil.

Considerando que o medicamento homeopático geralmente tinha baixo 
custo, o diretor do Centro de Saúde ponderou ser até possível oferecer o serviço de atendimento médico sem o fornecimento do medicamento, que na época era feito de forma indireta. Se o custo dos medicamentos aumentasse muito, o Centro de Saúde poderia não ter verbas suficientes para continuar arcando com o fornecimento.

\subsection{1 - Dados obtidos a partir de prescrições médicas:}

Através do rastreamento da totalidade das receitas advindas deste serviço, aviadas na farmácia homeopática conveniada durante os meses de março e abril de 1996, foi feita uma listagem. Desta forma foi possivel ter uma idéia de como eram as prescrições médicas, ainda que elas pudessem conter alteraçōes sazonais. Foram analisadas 126 receitas em relação à quantidade e o tipo dos medicamentos prescritos, suas associaçōes, forma farmacêutica e posologia. O aviamento dessas 126 receitas (45 do mês de março e 81 do més de abril), gerou 176 frascos de medicamentos (60 em março e 116 em abril), o que significa uma média de 1,4 frascos de medicamentos de todos os tipos por receita.

Fazendo grupamento dos dados obtidos podemos verificar que, em média, $86 \%$ das receitas de março e abril de 1996 continham apenas medicamentos homeopáticos. As receitas restantes apresentavam medicamentos homeopáticos prescritos junto com tintura de uso interno, essência floral para uso interno, creme com essência floral ou mineral (TABELA 2). 
TABELA 2: composiçăo das receitas, segundo os diferentes tipos e modalidades terapéuticas, encontradas no aviamento feito pela farmácia homeopática HN-Cristiano, durante os meses de março e abril de 1996, provenientes do CSE-GPS.

\begin{tabular}{|c|c|c|c|c|}
\hline \multirow[t]{2}{*}{ 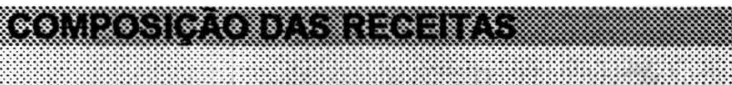 } & \multicolumn{2}{|c|}{ H } & \multicolumn{2}{|c|}{ 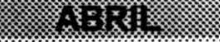 } \\
\hline & $\mathrm{N}$ & $\%$ & 6 & $\%$ \\
\hline 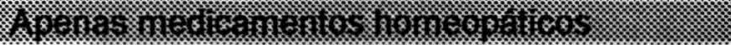 & 3.8. & 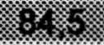 & 356. & 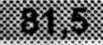 \\
\hline fomeopatia + MElitura de uso ineno. & 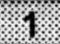 & $2,2,2$ & 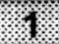 & $1 \times 2$ \\
\hline 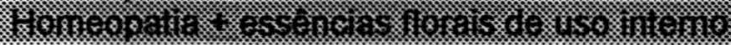 & ; & 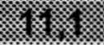 & 8 & 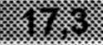 \\
\hline Womeopatia + Creme com essencias forais & 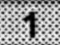 & $2,2$. & 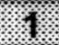 & 1,2 \\
\hline km & ; & (8) & (2.) & 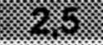 \\
\hline TOTAL DE RECETLS AVAD/S & 46 & 100,0 & 810 & 1000 \\
\hline
\end{tabular}

Detendo-nos sobre as prescriçőes que continham apenas medicamentos homeopáticos, teríamos uma distribuiçăo conforme a Tabela 3 , onde percebemos que a utilização de um medicamento, em uma potência única, responde por $80,8 \%$ do total $(81,6 \%$ em março e $80,3 \%$ em abril).

TABELA 3: composiçăo das receitas nas quais constam apenas medicamentos homeopáticos em aviamento feito pela farmácia homeopática $\mathrm{HN}$ Cristiano, durante os meses de março e abril de 1996, provenientes do CSE-GPS.

\begin{tabular}{|c|c|c|c|c|c|c|}
\hline \multirow[t]{2}{*}{ 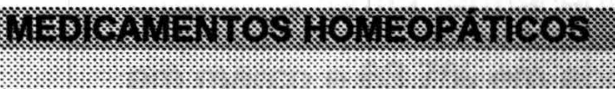 } & \multicolumn{2}{|c|}{ 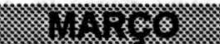 } & \multicolumn{2}{|c|}{$(z=3)$} & \multicolumn{2}{|c|}{ 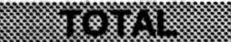 } \\
\hline & $n$ & 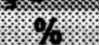 & m & $8 \%$ & $\mathrm{~m}$ & $\%$ \\
\hline 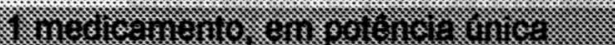 & 8 & 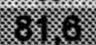 & 80 & 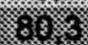 & $3 x$ & $80 \%$ \\
\hline I medicamento. 3 poteneias olierentes & 2. & 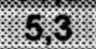 & 3 & $4,6$. & (5) & $4 x^{2}$ \\
\hline 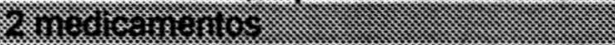 & 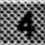 & 1885 & 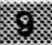 & 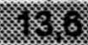 & 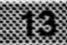 & $\frac{15}{8.3}$ \\
\hline 3 medicannentos: & 0 & 0.0 & Xxt & 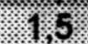 & 依 & 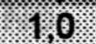 \\
\hline 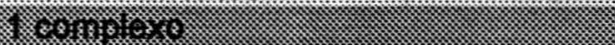 & 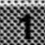 & 28 & $8 \%$ & $8:$ & 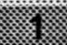 & 3 \\
\hline TOIA B BEREAEIAS & 838 & 10000 & 66 & 6000 & 804 & 6000 \\
\hline
\end{tabular}

Em relaçăo às potências dos medicamentos prescritos, percebemos alguma concentração na $6 \mathrm{CH}$ e na $30 \mathrm{CH}$. Somando-se as cinco potências mais prescritas $(6,9,12,18$ e $30 \mathrm{CH})$ chegamos a $77,0 \%$ das prescriçőes. Notamos ainda na Tabela 4 que houve prescrição de 10 outras potências diferentes, que incluíam até mesmo uma prescrição em cada mês de um outro método de preparaçăo, a LM ou cinquenta-milesimal, introduzido por HAHNEMANN na 6a. edição de seu livro Organon ${ }^{(70)}$.

\footnotetext{
17 Entende-se por "Homeopatia" a prescriçăo de medicamento homeopático na forma derivada, isto é, dinamizado.
} 
TABELA 4: classificaçăo dos medicamentos homeopáticos, quanto à potência, encontrados nas receitas aviadas pela farmácia homeopática $\mathrm{HN}$ Cristiano, durante os meses de março e abril de 1996, provenientes do CSE-GPS.

\begin{tabular}{|c|c|c|c|c|c|c|}
\hline \multirow[t]{2}{*}{ X } & \multicolumn{2}{|c|}{ Mars } & \multicolumn{2}{|c|}{ A BEAL } & \multicolumn{2}{|c|}{ (15) } \\
\hline & n & $\%$ & n. & $\%$ & $\mathrm{~N}$ & $\%$ \\
\hline 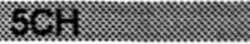 & 2. & $8: 8$ & (9. & 9. & 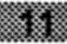 & 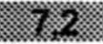 \\
\hline $6 \odot \mathrm{H}$ & 10 & 18.9 & 19 & 19,2 & 29 & 19.1 \\
\hline \% & 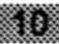 & 18.25 & 2. & 28 & 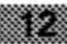 & 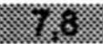 \\
\hline $12 \mathrm{CH}$ & 5. & 9.4 & 11 & 11,1 & 16 & 10,5 \\
\hline ( & $(x)$ & 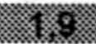 & 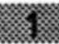 & 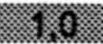 & 2 & 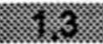 \\
\hline 18011 & 7 & 13,2 & 9 & 9.1 & 16 & 10.5 \\
\hline 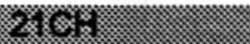 & 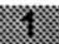 & 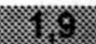 & 8 & $3:$ & 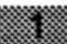 & $\varepsilon$, \\
\hline $24 \mathrm{CH}$ & 11 & 1.9 & 4 & 4.0 & 5. & 3,3 \\
\hline 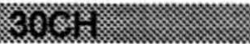 & 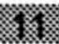 & $28 \%$ & $3 s$ & 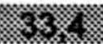 & $\mathbf{s}$ & 2898 \\
\hline 3604 & 0 & 0 & 2 & 20. & 2 & 1,3 \\
\hline WISEx & 8 & $\xi$ & 1 & 13 & 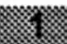 & 8 \\
\hline $20001+8200$ & 4 & $7 / 5$ & 5 & 5. & 9 & 5.9 \\
\hline 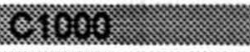 & 3 & 3 & 2 & 2 & 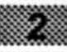 & 12 \\
\hline 1044 & 1 & 1.9 & 0 & 0 & 1. & 0.7 \\
\hline X & 3 & 3 & 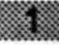 & 移 & ; & 5 \\
\hline TOTAL: & 53 & 100,0 & 99 & 100,0 & 152 & 100,0 \\
\hline
\end{tabular}

Quanto à forma farmacêutica, $\mathbf{7 1 , 7 \%}$ das prescriçōes foi de líquidos $\mathbf{( 7 7 , 4 \%}$ em março e 68,7\% em abril), como observamos na Tabela 5. É interessante notar que em uma pequena parte das receitas (5 em março e $6 \mathrm{em}$ abril) não havia especificaçăo da forma farmacêutica do medicamento. No momento de seu aviamento, o farmacêutico teve que decidir sobre líquidos ou glóbulos.

TABELA 5: classificaçăo dos medicamentos homeopáticos, quanto à forma farmacelutica, encontrados nas receitas aviadas pela farmácia homeopática HN-Cristiano, durante os meses de março e abril de 1996, provenientes do CSE-GPS.

\begin{tabular}{|c|c|c|c|c|c|c|}
\hline 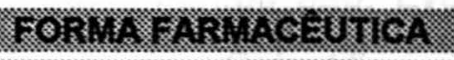 & \multicolumn{2}{|c|}{ in: $=$ - } & \multicolumn{2}{|c|}{ 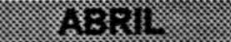 } & \multicolumn{2}{|c|}{ (Xox: : : } \\
\hline & n & $\%$ & n & $\%$ & $\mathrm{~N}$ & $\%$ \\
\hline 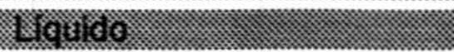 & 学要 & 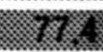 & 83 & 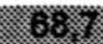 & 189 & $7 \%$ \\
\hline Glóbulos & 7 & 132 & 25 & 25.3 & 32 & 21.1 \\
\hline 1 & 5 & $8 \%$ & 6 & (x) & 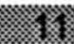 & 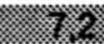 \\
\hline TOTAL: & 58 & 100,0 & 99 & 100,1 & 152 & 100,0 \\
\hline
\end{tabular}


A maior parte das prescrições $(71,7 \%)$ previa a utilização de doses repetidas, como percebemos na TABELA 6.

TABELA 6: classificaçăo dos medicamentos homeopáticos, quanto à posologia, encontrados nas receitas aviadas pela farmácia homeopática HNCristiano, durante os meses de março e abril de 1996, provenientes do CSE-GPS.

\begin{tabular}{|c|c|c|c|c|c|c|}
\hline 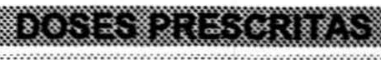 & \multicolumn{2}{|c|}{ H I I K } & \multicolumn{2}{|c|}{ X } & \multicolumn{2}{|c|}{ 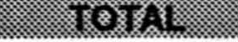 } \\
\hline & $\mathrm{n}$ & $\%$ & $n$ & $\%$ & 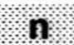 & $\%$ \\
\hline W km & zex. & 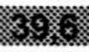 & 22 & 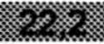 & 的数数 & 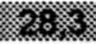 \\
\hline Multiplas. & 32 & 60.4 & 77 & $777 \%$ & 109 & $7 / 2.7$ \\
\hline $80 \times 4$ & 58 & 86 & 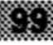 & $\%$ & 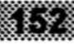 & $830 \%$ \\
\hline
\end{tabular}

Quanto às substâncias prescritas, observamos através da Tabela 7, que foram $\mathbf{5 0}$ diferentes. Em março as principais foram Lycopodium clavatum, Lachesis, Nux vomica, Phosphorus, Pulsatilla nigricans e Argentum nitricum. Já em abril foram Arsenicum album, Calcarea carbonica, Phosphorus, Pulsatilla nigricans, Lachesis e Lycopodium clavatum. Seis substâncias totalizaram $37,7 \%$ das receitas de março e $36,4 \%$ das receitas de abril, sendo que só quatro dessas substâncias foram comuns (Lycopodium clavatum, Lachesis, Phosphorus e Pulsatilla nigricans), aparecendo como principais nos meses de março e abril.

Verificando o total dos medicamentos prescritos nos dois meses, observamos que foram necessários 10 medicamentos (20,0\% do total) para atender a $\mathbf{5 1 , 3 \%}$ das prescriçöes, indicando uma certa dispersão entre os medicamentos utilizados. Esta dispersăo pode ser verificada também quando comparamos o que foi utilizado em cada um dos meses. Esses medicamentos săo: Lycopodium clavatum, Phosphorus, Arsenicum album, Lachesis, Pulsatilla nigricans, Nux vomica, Sulphur, Carcinosinum e Causticum.

Após coleta $e$ análise dos dados relativos aos medicamentos prescritos para pacientes atendidos pelo serviço médico homeopático, apresentamos a seguir uma sintese dos principais resultados. 


\begin{tabular}{|c|c|c|c|c|c|c|}
\hline \multirow{2}{*}{ 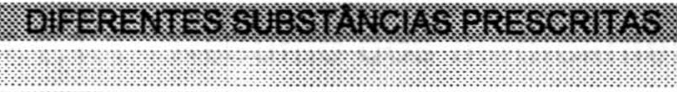 } & \multicolumn{2}{|c|}{ masos } & \multicolumn{2}{|c|}{ : } & \multicolumn{2}{|c|}{ 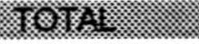 } \\
\hline & n. & $\%$ & $n$ & $\%$ & $\mathrm{n}$ : & $\%$ \\
\hline 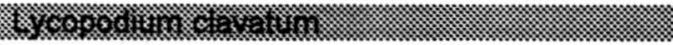 & 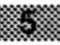 & 28 & $\sqrt{3}:$ & 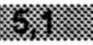 & 86 & $6:$ \\
\hline Phosphorus : & 4. & 2,5 & 6 & 6.1 & 10 & 6,6 \\
\hline 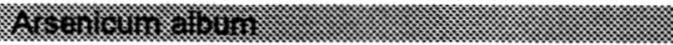 & 2. & 3.5 & 28 & 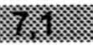 & (9) & $5 \times 2$ \\
\hline Calcarea carbonica. & 2 & 3,8: & 7 & 7.11 & 9 & 59 \\
\hline WA & 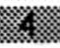 & $1 \%$ & s. & 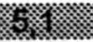 & $6 \times$ & 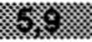 \\
\hline Pulsatilla nigricans. & 3 & $57:$ & 6. & 6.1. & 9 & $5 \%$ \\
\hline 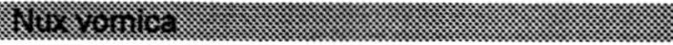 & 4 & 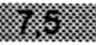 & 8 & 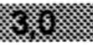 & $2 x$ & 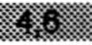 \\
\hline Sulphur: & 2 & 3,8 & 4 & 4.0 & 6. & 3.9 \\
\hline 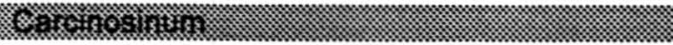 & 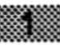 & 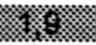 & 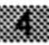 & 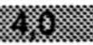 & $2 \times$ & 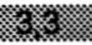 \\
\hline Causticum: & 32 & $3.8 \%$ & 3. & 30 & 5 & 3.3 \\
\hline 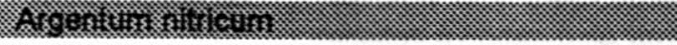 & ; & in & $=$ & 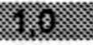 & 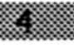 & $2 \times 2 x$ \\
\hline Bryonia alba & 11 & 1.9 & 3. & 3.0 & 4 & 26 \\
\hline 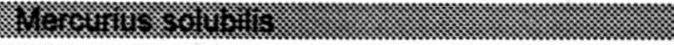 & 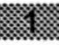 & 2. & 3 & 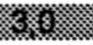 & $2 \times$ & $2 \times$ \\
\hline Psorinum & 1 . & 199 & 3. & 3,0 & 4 & 2.6 \\
\hline 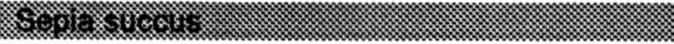 & 2 & is & 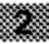 & 2 & 永 & 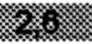 \\
\hline Yeratrum ailbum & 11 & $19 \%$ & 3 & $30 \%$ & 4. & 26 \\
\hline Fing & , & $(x)$ & 2 & 3 & 2 & 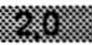 \\
\hline Blatta orientalis & 0 & $0,0 \%$ & 3. & 380 & 3. & 20 \\
\hline S & 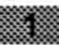 & $\sqrt{3} 32$ & 2 & $2 / 3$ & 2 & 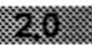 \\
\hline Lens sculenta: & 1 & 199 & 2 & 2.0 & 3 & 28. \\
\hline 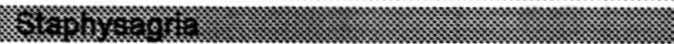 & 8 & 83 & 3 & 3 & 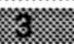 & 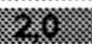 \\
\hline Belladonna & 0. & $0.0 \%$ & 2 & $2,0$. & 2 & 1,3 \\
\hline 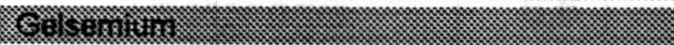 & 8 & 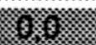 & 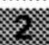 & 283 & 2 & I. \\
\hline Ipeca & II. & $19 \%$ & (1) & $(100$ & 2 & $1 / 3$ \\
\hline 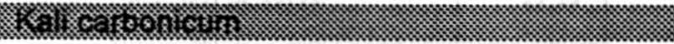 & 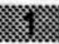 & 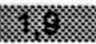 & 2 & 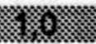 & (2) & $m$ \\
\hline Silicea . & 11 & 199 & to & 100 & 2 & 1,33 \\
\hline 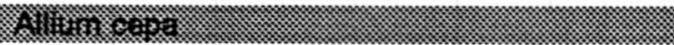 & 3 & $3 \times 3$ & 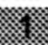 & 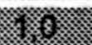 & 1 & 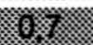 \\
\hline Aloe & 0 & $0.0 \%$ & 4. & 10. & 11 & 0,7 \\
\hline 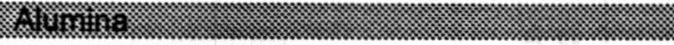 & 3 & 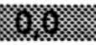 & 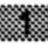 & 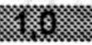 & 12 & 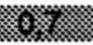 \\
\hline Banta carbonlea & 0 & 0,0 & 4 & 100 & 1/x & $0 \%$ \\
\hline 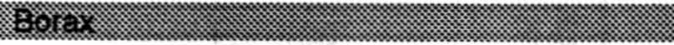 & ; & ? & 8 & $8 \times 3$ & 12 & $8 \times 2$ \\
\hline China officinalis & 0 & $00 \%$ & 4 & 100 & 1. & 0,7 \\
\hline 28 & . & $x$ & 8 & 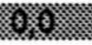 & 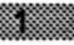 & 8 \\
\hline Drosera & 0 & 0,0 & 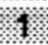 & 110 & 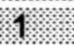 & $0 \%$ \\
\hline S & 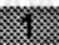 & 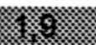 & 8 & 8 & $x$ & $8 \times$ \\
\hline Ferrum metalloum & 0 & 0.0. & 1. & 160 & 12 & 07 \\
\hline W & 8 & 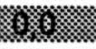 & 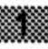 & $\sqrt[2]{2}$ & (1) & 8 \\
\hline Hypertcam pertoratum: & 0 & 0.0. & 1. & 10 & 位 & $8 \%$ \\
\hline 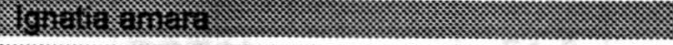 & 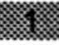 & 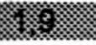 & 8 & 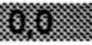 & $x=$ & $8 \%$ \\
\hline Modorthinum & 0 & 0.0 & 1 & $1 / 0$ & 10 & $0 \%$ \\
\hline K & $x$ & 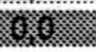 & 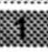 & $(x)$ & $m$ & 8 \\
\hline Natrum phosphoricum & 0 & 0.0 & 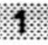 & 190 & 位 & $0,0$. \\
\hline Hew & in & 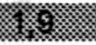 & 8 & 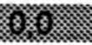 & 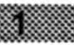 & $88 \%$ \\
\hline Rhus toxicodendion & 11. & 4.9. & 0. & 0.0 & 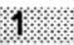 & 0,7 \\
\hline 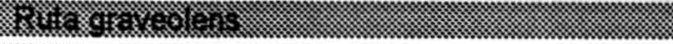 & 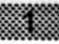 & $\ldots$ & 2 & 83 & 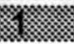 & $(2)$ \\
\hline Stramonlum & 0 & 00. & 1 & 190 & 11 & $87 \%$ \\
\hline Kats & $=$ & 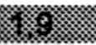 & (3) & 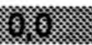 & 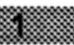 & 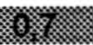 \\
\hline Tuberculinum & 0 & $0,0 \%$ & $1 \%$ & 100 & $1 \times$ & 07. \\
\hline K & 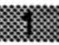 & 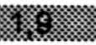 & 8 & 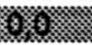 & x. & 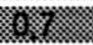 \\
\hline Valetana officinalis: & 0. & $0.0 \%$ & I. & 10 & 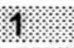 & $0,7 \times$ \\
\hline 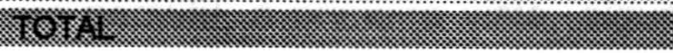 & m & $(288 \times 8$ & 92 & 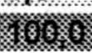 & m. & $(3)$ \\
\hline
\end{tabular}




\subsubsection{1 - Resumo dos medicamentos homeopáticos mais prescritos}

O Quadro 2 mostra uma síntese das prescrições mais freqüentes deste serviço.

QUADRO 2: resumo dos medicamentos homeopáticos mais prescritos nas receitas aviadas pela farmácia homeopática HN-Cristiano, durante os meses de março e abril de 1996, provenientes do CSE-GPS.

\begin{tabular}{|c|c|c|c|}
\hline \multirow{3}{*}{ Substância } & \multirow{3}{*}{$\%$} & Potência & $\%$ \\
\hline & & $6 \mathrm{CH}$ & 19,1 \\
\hline & & $9 \mathrm{CH}$ & 7,9 \\
\hline Lycopodium & 6,6 & $12 \mathrm{CH}$ & \\
\hline Phosphorus & 6,6 & 12018 & 10,0 \\
\hline \multirow{2}{*}{ Arsenicum } & \multirow{2}{*}{5,9} & $18 \mathrm{CH}$ & 10,5 \\
\hline & & $30 \mathrm{CH}$ & 29,0 \\
\hline Calcarea & 5,9 & outras & 23,0 \\
\hline Lachesis & 5,9 & \multirow{2}{*}{ TOTAL } & \multirow{2}{*}{77,0} \\
\hline Pulsatilla & 5,9 & & \\
\hline Nux vomica & 4,6 & \multirow{2}{*}{$\begin{array}{c}\text { Forma } \\
\text { farmacêutica. }\end{array}$} & \multirow[t]{2}{*}{$\%$} \\
\hline Sulphur & 3,9 & & \\
\hline Carcinosinum & 3,3 & Líquida & 71,7 \\
\hline Causticum & 3,3 & \multirow[t]{2}{*}{ Outras } & \multirow[t]{2}{*}{28,3} \\
\hline outras & 48,1 & & \\
\hline \multirow{2}{*}{ TOTAL } & \multirow{3}{*}{51,9} & Posologia & $\%$ \\
\hline & & Dose repetida & 71,7 \\
\hline & & Dose única & 28,3 \\
\hline
\end{tabular}

Observando os resultados obtidos com a análise da amostra do estudo piloto, verificamos que apenas alguns pontos são suficientemente densos para permitir, à primeira vista, algum tipo de padronização. A maior parte 
das prescriçōes foram em forma líquida e doses repetidas, porém foi bastante extensa a variedade de substâncias prescritas, mesmo sendo originadas do receituário de apenas 3 médicos homeopatas, que atendem a uma determinada população, em um mesmo local.

Pode-se imaginar que, ao considerar um maior número de médicos, provenientes de diversas escolas homeopáticas, em diversos serviços (o contato entre médicos que atendem em um mesmo local talvez possa homogeneizar parcialmente a forma de atendimento, e consequentemente 0 tipo de prescrições) e uma população diversificada em suas características e sintomas, a variabilidade encontrada entre os medicamentos prescritos seria bem maior.

\subsection{2 - Comparação com os resultados de MOREIRA NETO ${ }^{(113)}$ :}

Comparando os dados obtidos no estudo piloto com aqueles de MOREIRA NETO, percebemos semelhanças entre as potências, apesar de nossos dados conterem prescriçōes de apenas 2 meses. Considerando as 10 substâncias mais prescritas, $80 \%$ delas coincidem (Arsenicum album, Calcarea carbonica, Carcinosinum, Lachesis, Lycopodium clavatum, Nux vomica, Phosphorus e Sulphur), porém aparecem agora também Natrum muriaticum e Silicea. Os 10 medicamentos totalizam $54,9 \%$ das prescrições, valor muito próximo do observado do CSE-GPS $(51,9 \%)$. O autor também citou terem sido utilizados 35 diferentes medicamentos na 1a. consulta de 94 pacientes, contra 50 substâncias do estudo piloto ${ }^{(99)}$ (QUADRO 3 ).

Quando comparamos os resultados dos dois estudos, realizados no mesmo serviço, percebemos que entre as 10 substâncias mais prescritas, 8 foram comuns. Houve coincidência em relação às potências mais prescritas, assim como à forma farmacêutica e à posologia. 
QUADRO 3: comparaçåo entre os dados obtidos no estudo piloto no CSE-GPS e os de MOREIRA NETO.

\begin{tabular}{|l|c|c|}
\hline Medicamento & $\begin{array}{c}\text { Piloto } \\
\%\end{array}$ & $\begin{array}{c}\text { M Neto } \\
\%\end{array}$ \\
\hline Lycopodium & 6,9 & $\mathrm{X}$ \\
\hline Phosphorus & 6,6 & $\mathrm{X}$ \\
\hline Arsenicum & 5,6 & $\mathrm{X}$ \\
\hline Calcarea & 5,9 & $\mathrm{X}$ \\
\hline Lachesis & 5,9 & $\mathrm{X}$ \\
\hline Pulsatilla & 5,9 & - \\
\hline Nux vomica & 4,6 & $\mathrm{X}$ \\
\hline Sulphur & 3,9 & $\mathrm{X}$ \\
\hline Carcinosinum & 3,3 & $\mathrm{X}$ \\
\hline Causticum & 3,3 & - \\
\hline Natrum mur. & - & $\mathrm{X}$ \\
\hline Silicea & - & $\mathrm{X}$ \\
\hline Outros & 48,1 & $\mathbf{4 5 , 1}$ \\
\hline TOTAL & 100,0 & 100,0 \\
\hline
\end{tabular}

\begin{tabular}{|l|r|r|}
\hline \multicolumn{1}{|c|}{ Poténcia } & $\begin{array}{r}\text { Piloto } \\
\%\end{array}$ & \multicolumn{1}{c|}{$\begin{array}{c}\text { M Neto } \\
\%\end{array}$} \\
\hline $6 \mathrm{CH}$ & 19,1 & 24,4 \\
\hline $9 \mathrm{CH}$ & 7,9 & 5,8 \\
\hline $12 \mathrm{CH}$ & 10,5 & 13,3 \\
\hline $18 \mathrm{CH}$ & 10,5 & 10,5 \\
\hline $30 \mathrm{CH}$ & 29,0 & 18,0 \\
\hline TOTAL & 77,0 & 72,0 \\
\hline
\end{tabular}

X - Medicamentos citados por $M$. Neto, que constam entre os mais prescritos.

\subsection{3 - Comparação com dados de 1986:}

Estes dados foram comparados com outros obtidos em 1986, a partir de receitas aviadas durante dois meses na mesma farmácia homeopática, porém naquela época provenientes de diversos médicos homeopatas, na sua quase totalidade atendendo em suas clínicas particulares ${ }^{(40)}$.

Naquela amostra verificou-se que foram prescritos principalmente medicamentos sob a forma de glóbulos, na proporção de $77,8 \%$, o que contraria os resultados encontrados nas receitas do Centro de Saúde (Tabela 8$)^{\left({ }^{(40)} \text {. }\right.}$ 
TABELA 8: classificaçăo dos medicamentos homeopáticos, quanto à forma farmacéutica, encontrados nas receitas aviadas pela farmácia homeopática HN-Cristiano, durante dois meses do ano de 1986, provenientes de diversos médicos homeopatas ${ }^{(40)}$.

\begin{tabular}{|c|c|}
\hline HofHS: & 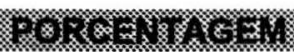 \\
\hline Líguidos : : & $: .: 172 \%$ \\
\hline 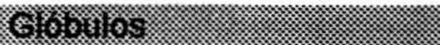 & (1) \\
\hline TOTAL: & $100,0 \%$ \\
\hline
\end{tabular}

$\mathrm{Na}$ amostra anterior também foram encontradas mais prescrições de doses repetidas do que doses únicas, ainda que a proporção tenha sido mais semelhante naquela época (Tabela 9) ${ }^{(40)}$.
TABELA 9: classificaçăo dos medicamentos homeopáticos, quanto à posologia, encontrados nas receitas aviadas pela farmácia homeopática $\mathrm{HN}$ - Cristiano, durante dois meses do ano de 1986, provenientes de diversos médicos homeopatas ${ }^{(40)}$.

\begin{tabular}{|c|c|}
\hline 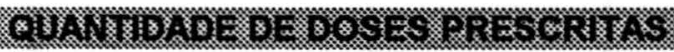 & 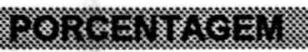 \\
\hline Onica & (: \\
\hline Mration & 3. \\
\hline TOTAl. & $100 \%$ \\
\hline
\end{tabular}

Em relaçăo às diferentes substâncias prescritas, 10 diferentes tipos foram utilizadas para preparar $65,9 \%$ dos medicamentos solicitados. Foram elas: Sulphur, Lycopodium clavatum, Pulsatilla nigricans, Natrum muriaticum, Nux vomica, Phosphorus, Calcarea carbonica, Arsenicum album, Chamomilla e Silicea ${ }^{(40)}$.

Comparando com as substâncias prescritas no CSE-GPS, durante o mês de março, 62,3\% das receitas foram atendidas com 11 diferentes substâncias. No mês de abril, $65,6 \%$ das receitas do Centro de Saúde foram atendidas com 15 diferentes substâncias. 
QUADRO 4: comparaçăo entre os dados obtidos no estudo piloto e receitas aviadas pela farmácia homeopática HN-Cristiano, em 1986.

\begin{tabular}{|l|c|c|}
\hline Medicamento & Piloto\% & $\begin{array}{c}\text { HN-C (86) } \\
\%\end{array}$ \\
\hline Lycopodium & 6,9 & 8,3 \\
\hline Phosphorus & 6,6 & 5,1 \\
\hline Arsenicum & 5,6 & 4,7 \\
\hline Calcarea & 5,9 & 4,9 \\
\hline Lachesis & 5,9 & - \\
\hline Pulsatilla & 5,9 & 8,3 \\
\hline Nux vomica & 4,6 & 5,4 \\
\hline Sulphur & 3,9 & 10,5 \\
\hline Carcinosinum & 3,3 & - \\
\hline Causticum & 3,3 & - \\
\hline Natrum mur. & - & 6,9 \\
\hline Chamomilla & - & 4,2 \\
\hline Silicea & - & 2,9 \\
\hline TOTAL & 51,9 & 65,9 \\
\hline
\end{tabular}

A comparaçăo entre o resumo dos dados das receitas dispensadas durante dois meses, provenientes do CSE-GPS e sua comparaçăo com aquelas aviadas durante dois meses, na mesma farmácia, porém dez anos anos antes, mostra uma coincidência de 7 medicamentos entre aqueles que mais foram prescritos. Em relação à forma farmacêutica, diferente desta situação, o estudo anterior mostrou uma preferência por glóbulos, além de maior freqüência de doses repetidas.

\section{2 - O Centro de Terapia Alternativa (CTA) do Posto de Saúde Municipal "Agostinho Neto", em Itú.}

O Centro de Terapia Alternativa do Posto de Saúde Municipal "Agostinho Neto" localizado Itú, SP, à época da visita ao serviço, contava com 
atendimento médico homeopático diário, constituindo a equipe de uma coordenadora, 5 médicos homeopatas, que atendiam de 2a. a 6 a. feiras num total de 64 horas por semana, além de 2 médicos acupunturistas (48 horas/semana no total). Segundo a coordenadora, havia uma demanda reprimida, especialmente na área de Pediatria. Seu objetivo era ampliar o atendimento para horário noturno e aos sábados, para alcançar um maior número de pacientes do sexo masculino.

Em relação ao atendimento homeopático, eram agendadas 6 consultas por período, conforme recomendação da $\mathrm{AMHB}$, sendo: 1 paciente novo e 5 retornos. Habitualmente eram atendidos ainda 1 ou 2 casos de intercorrência de pacientes já em atendimento rotineiro. Quando um médico atendia a paciente de outro clínico, não podia alterar a medicação anterior sem uma justificativa. No atendimento de Acupuntura, eram atendidos 2 casos novos e 10 retornos por período.

Além do atendimento médico homeopático e em Acupuntura, existia o projeto de Fitoterapia, dedicado ao preparo de um complexo alimentício utilizando folhas de mandioca seca e torrada, com sementes de girassol, arroz, etc. Um convênio com uma escola de Massagem Oriental oferecia esta terapéutica através de 11 profissionais que atendiam durante 2 sábados por mês, gratuitamente, como forma de estágio de sua formação, assistidos por coordenadores. Este atendimento exigia horas extras de trabalho de funcionários do Centro de Saúde, mas era extremamente apreciado pela comunidade.

O CTA gostaria de implantar também o projeto de Musicoterapia, especialmente direcionado a gestantes, crianças e à terceira idade.

Com a finalidade de informar à clientela atendida, na sala de espera do CTA, existia um painel com informações, revistas e folhetos, além de livros 
sobre Homeopatia, Fitoterapia, Terapia Floral e Massagem Oriental, que podiam ser retirados para leitura posterior.

A Normatização Farmacêutica da Prefeitura de ltú não incluía medicamentos homeopáticos. Foi feito então um convênio com a Farmácia Lírio D'Água, que possibilitava que os medicamentos homeopáticos fossem fornecidos gratuitamente para os pacientes carentes, quando então as receitas eram carimbadas como "convênio social".

Para estabelecer o convênio, todas as farmácias foram visitadas e verificadas sua estrutura e a manipulação. Percebeu-se que havia uma deficiência no contato entre farmacêuticos e médicos, e que estes tinham dúvidas na hora de prescrever.

Um convênio, formalmente documentado, foi feito com a Farmácia Lírio D'Água. Seu estoque era limitado, e medicamentos não abrangidos, eram fornecidos após alguns dias.

Frascos de medicamento vazios, devolvidos por pacientes, eram lavados no próprio Centro de Saúde, por uma auxiliar. O estabelecido foi que cada 4 frascos, valiam um novo medicamento. Na prática, a farmácia vinha doando medicamentos, mesmo antes deste convênio. Foi feita uma campanha na midia (radio e TV), para que a população auxiliasse trazendo frascos vazios de medicamentos, para serem reciclados.

Uma triagem feita na 1a. consulta, por uma auxiliar de enfermagem, permitia classificar os pacientes que não pagariam pelos medicamentos, através de seu local de residência, sua aparência e história pessoal. Cerca de $30 \%$ dos pacientes atendidos no Centro de Saúde possuiam boa condição socioeconômica, sendo que a coordenadora do serviço imaginava que nos outros locais esta freqüência seria no máximo de $5 \%$. Era sua opinião que a 
população atendida pelo serviço não podia ser informalmente classificada como "muito pobre", já que não existiam favelados na região. Os problemas da cidade relacionados à violência urbana eram mais freqüentes entre as classes média alta e superior, compreendendo suicídios, assassinatos, acidentes de carro, etc.

A Farmácia atendia a prescriçōes de organoterápicos ${ }^{18}$, minerais quelados, cremes, pomadas, fitoterápicos (cápsulas, chás, tinturas). Quando era prescrito medicamento alopático, ele podia ser retirado no Posto de Saúde. Quando algum medicamento homeopático não fosse disponivel, era solicitado por SEDEX para São Paulo ou em farmácias de cidades vizinhas.

Outro convênio foi estabelecido para fornecimento de agulhas para Acupuntura, que anteriormente eram vendidas no CTA. Na época da visita esta venda também ocorria na Farmácia acima, sendo que ao pacientes carentes não pagavam por elas.

Estes convênios possibilitavam que sobrassem recursos para a compra de livros, ventiladores, aquecedores para a sala de Acupuntura, etc.

Os dados acumulados sobre a procedência dos pacientes, sexo, data de nascimento e presença nos retornos não estavam disponiveis. Estimava-se que a ausência aos retornos era de cerca de $15 \%$ do agendamento mensal.

As principais patologias eram as femininas (menopausa, osteoporose, corrimentos, ansiedade, distúrbios neurovegetativos), as alérgicas, de vias digestivas (colites e alergias alimentares) e respiratórias (provavelmente devido à presença de muitas olarias na regiăo, associadas à ocorrência de problemas de asma, rinites, bronquites e silicose).

18 Organoterapia é o tratamento da doença através da administraçăo de pequenas quantidades de extratos de órgåos derivados de animais saudáveis. Isto estimula o órgăo doente a funcionar de modo normal ou mais saudável ${ }^{(133)}$. 
Em relaçăo à clientela, muitos idosos procuravam o CTA, principalmente para tratamento por Acupuntura, provavelmente devido a dores articulares, artroses e lombalgias, assim como para $\circ$ atendimento de Massagem Oriental. Um menor número de homens eram atendidos, provavelmente devido ao horário ser diurno. Em vista disto a coordenadora queria estender este atendimento para até as 21 horas.

O encaminhamento dos pacientes era misto, vindo de várias partes, de vários Municípios, como São Paulo, Campinas, Sorocaba, Indaiatuba, Porto Feliz, Salto, Itapetininga, Nova Odessa, Rio Claro, Itupeva, Jundiaí, Cabreúva, etc.

Pacientes que necessitavam de atendimento de urgência (ou durante horários em que o CTA não funcionava) e que dirigiam-se para a Santa Casa ou para o PAM (Posto de Atendimento Médico), raramente recebiam críticas em relação à opção pelo tratamento homeopático, por parte dos alopatas.

Existia liberdade para prescrição de Homeopatia, Acupuntura, Fitoterapia, moxa, ventosas, essências florais e ortomolecular, porém só havia agendamento para Homeopatia, Acupuntura e Massagem Oriental.

Os medicamentos anteriormente prescritos para diabetes e hipertensão, por exemplo, eram mantidos; a dosagem de corticóides era reduzida aos poucos; antibióticos prescritos em atendimento de Pronto-Socorro não eram interrompidos. Eram indicados vermífugos, vitaminas e outros medicamentos alopáticos, quando necessário.

A coordenadora considera que o êxito do atendimento médico homeopático está diretamente relacionado com uma solução pessoal, que foi o acordo de colaboração para fornecimento dos medicamentos. Anteriormente à vigência 
do acordo, os pacientes precisavam buscar os medicamentos prescritos onde encontrassem.

Durante a elaboração deste trabalho, houve uma alteração da coordenadoria (a coordenadora responsável pela implantação do CTA foi substituída, permanecendo apenas no atendimento médico, e posteriormente saindo definitivamente do serviço). O convênio com a farmácia continuaria ocorrendo enquanto existissem frascos de vidro para serem trocados por medicamentos. Depois disto esta forma de convênio deveria ser desativada, passando para métodos mais convencionais, como concorrência pública ou carta-convite, aberta a todas as farmácias da cidade. No inicio de 1999, pacientes carentes recebiam um carimbo na prescrição e continuavam a receber o medicamento gratuitamente.

\subsection{1 - Dados das prescrições da Farmácia Lírio D'Água:}

Com a finalidade de obter informações sobre os medicamentos indicados aos pacientes do Centro de Saúde, foram analisadas a cópia das folhas do caderno onde estavam as anotaçōes de 128 prescriçōes aviadas pela Farmácia Lírio D'Água, de 25 de maio de 1996 até 14 de novembro de 1997, aos pacientes carentes encaminhados pelo serviço.

A maior parte destas prescrições $(78,1 \%)$ continha apenas medicamentos homeopáticos. As prescrições restantes apresentavam também medicamentos homeopáticos prescritos junto com Fitoterápicos (que englobam aqui tinturas vegetais de uso interno ou externo, assim como cápsulas com vegetais secos em pó), medicamentos para uso externo e ou essências florais, conforme pode ser visto na Tabela 10. 
TABELA 10: composiçăo das receitas, segundo os diferentes tipos e modalidades terapéuticas, nas prescriçōes aviadas pela farmácia homeopática Lírio D'Água, de 25 de maio de 1996 até 14 de novembro de 1997, provenientes do CTA do Posto de Saúde de Itú.

\begin{tabular}{|c|c|c|}
\hline 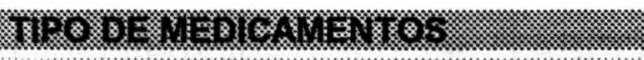 & 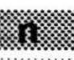 & $=8$ \\
\hline Apenas medicamentos homeopaticos & 100 & $78.1 \%$ \\
\hline 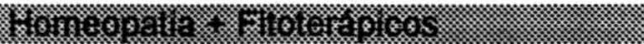 & 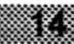 & $18 \times x$ \\
\hline Homeopatia + esséncúas florais: & 5 & $3,9 \%$ \\
\hline 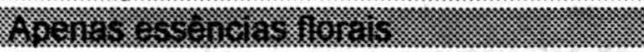 & 4 & 3. \\
\hline Apenas medicamentos para uso externo & 3 & $2.4 \%$ \\
\hline A & 2. & 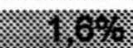 \\
\hline TOTAL BEREGETIAS & 128 & $100,0 \%$ \\
\hline
\end{tabular}

Dentre estas receitas, observando as 119 prescrições que continham medicamentos homeopáticos, unicamente ou associados a Fitoterapia ou essências florais, percebemos que a maior parte (68\%), apresentava somente um medicamento, em potência única (Tabela 11).

TABELA 11: classificaçăo das prescriçoes de medicamentos homeopáticos em
relaçăo aos outros medicamentos que os acompanham, em
receitas aviadas pela farmácia homeopática Lírio D'Agua, de 25 de
maio de 1996 até 14 de novembro de 1997, provenientes do CTA
do Posto de Saúde de Itú.

Estas 119 prescrições relacionadas na TABELA 11 traziam a indicação de 146 substâncias dinamizadas ${ }^{19}$, cujas principais potências utilizadas,

19 Portanto, cada prescriçăo continha, em média, a indicaçăo de 1,2 substâncias dinamizadas. 
concentraram-se em $6 \mathrm{CH}, 12 \mathrm{CH}, 30 \mathrm{CH}$ e $200 \mathrm{CH}^{20}$. Somando-se a porcentagem destas 4 potências chegamos a $71,2 \%$ das substâncias dinamizadas prescritas nas 119 receitas, sendo que as restantes foram solicitadas em 19 diferentes potências (TABELA 12).

TABELA 12: classificaçăo dos medicamentos homeopáticos, quanto às poténcias, encontrados nas receitas aviadas pela farmácia homeopática Lírio D'Água, de 25 de maio de 1996 até 14 de novembro de 1997, provenientes do CTA do Posto de Saúde de Itú.

\begin{tabular}{|c|c|c|}
\hline 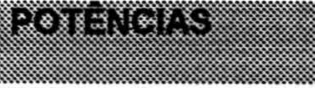 & 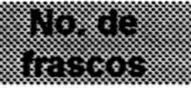 & (5) \\
\hline $60 \mathrm{H}$ & . & 17,8 \\
\hline 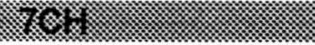 & , & 4. \\
\hline $90 \%$ & 3 & 21 \\
\hline (2) & 82 & 8: \\
\hline $1501 \%$ & 2 & 1.3 \\
\hline$x$ & $x$ & 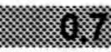 \\
\hline 1704 & 1 & 0.6 \\
\hline (6) & 位 & 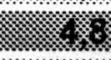 \\
\hline 1084 & 稵 & $0 \%$ \\
\hline s. & $x$ & 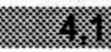 \\
\hline 2184 & 3 & 20 \\
\hline 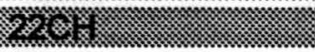 & x. & $x$ \\
\hline $230 \%$ & 18 & $0 \%$ \\
\hline 8 & x & 28.6 \\
\hline $450 \%$ & 11 & 0.7 \\
\hline (j) & s. & 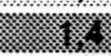 \\
\hline 9004 : & 1.9 & 07 \\
\hline $2882 \times 1$ : & 新 & $\times$ \\
\hline C203: & 1 & 0.7 \\
\hline 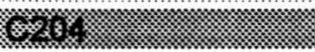 & 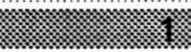 & 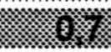 \\
\hline 01000 & Xx & $0 \%$ \\
\hline Q 26 & $x$ & 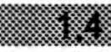 \\
\hline 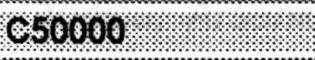 & 2 & $1 / 4$ \\
\hline H & 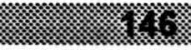 & 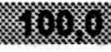 \\
\hline
\end{tabular}

Quanto à forma farmacêutica, $67,1 \%$ das prescrições foram líquidas. Não houve anotação por parte da farmácia quanto à forma farmacêutica de 10 frascos, embora é possivel que existisse na receita original (Tabela 13).

20 Para efeito de cálculos, neste trabalho, as prescriç̋es $\mathrm{CH}$ (método centesimal hahnemanniano) foram consideradas junto com as FC (método mecânico de Fluxo Contínuo), ou ainda as descritas apenas como C, que so especificam a escala centesimal. 
TABELA 13: classificaçăo dos medicamentos homeopáticos, quanto à forma farmacéutica, encontrados nas receitas aviadas pela farmácia homeopática Lírio D'Água, de 25 de maio de 1996 até 14 de novembro de 1997, provenientes do CTA do Posto de Saúde de Itú.

\begin{tabular}{|c|c|c|}
\hline 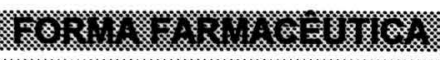 & 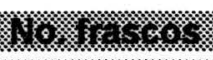 & \% \\
\hline liqudo.:. & $1.1 . .198$ & 671 \\
\hline 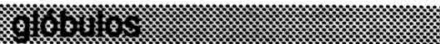 & $8 \%$ & 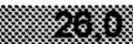 \\
\hline nâo deterrininada. & 10 & 6.9 \\
\hline 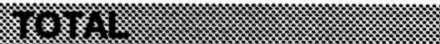 & 286 & 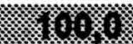 \\
\hline
\end{tabular}

A maior parte das prescrições $(92,5 \%)$ previa a utilização de doses repetidas, como consta da TABELA 14.

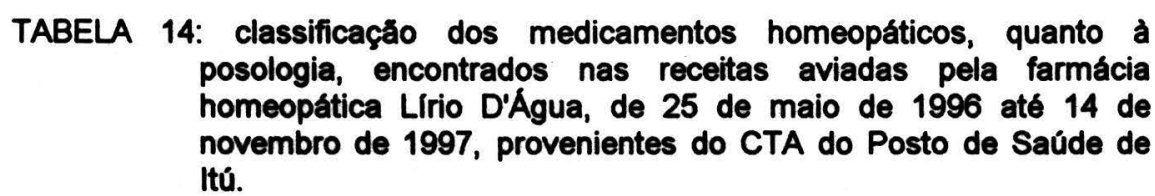

\begin{tabular}{|c|c|c|}
\hline 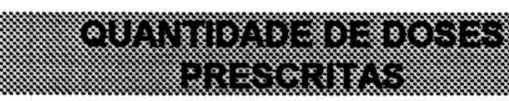 & 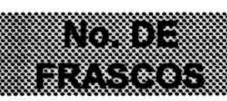 & $\%$ \\
\hline Unica & $=135$ & 92.5 \\
\hline 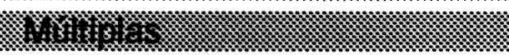 & 1. & $7 / 5$ \\
\hline Total : : & 146 & 1000. \\
\hline
\end{tabular}

Foram 43 diferentes substancias prescritas, conforme observamos na TABELA 15.

As 10 substâncias mais indicadas somam $60,1 \%$ das prescriçōes e foram elas: Baryta carbonica, Arsenicum album, Belladonna, Pulsatilla nigricans, Sepia succus, Calcarea carbonica, Phosphorus, Lachesis, Arnica, Pulmo histaminum e Veratrum album. A TABELA 16 mostra os 10 medicamentos dinamizados mais prescritos.

Além destes medicamentos homeopáticos, foram aviados na farmácia, 9 frascos de tintura-mãe, 11 de florais, 3 de creme, 1 de pomada, 1 de gel, 3 de gliceróleo, 1 de sabonete cremoso e 1 frasco de própolis com mel. 
Novamente neste serviço, observamos que apenas alguns pontos são suficientemente densos para permitir algum tipo de padronização no fornecimento. 
TABELA 15: classificaçăo dos medicamentos homeopáticos encontrados nas receitas aviadas pela farmácia homeopática Lírio D'Água, de 25 de maio de 1996 até 14 de novembro de 1997, provenientes do CTA do Posto de Saúde de Itú.

\begin{tabular}{|c|c|c|}
\hline 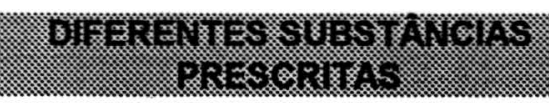 & $\operatorname{lin}_{10}$ & $\%$ \\
\hline Alliun cepa , & .8 .2 & 14 \\
\hline A K K & 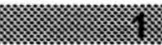 & 86 \\
\hline Amica montana & 5. & 3.4 \\
\hline A & 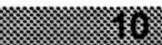 & 68 \\
\hline Arum 1 iployilum : & 位 & 06 \\
\hline 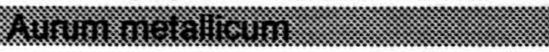 & 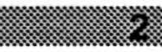 & 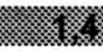 \\
\hline Autoisoterapico & 1 & 06 \\
\hline 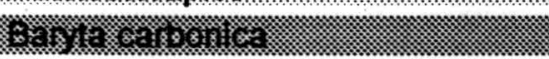 & 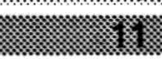 & 然: \\
\hline Belladonna : & 10 & 6.9 \\
\hline 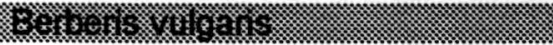 & wis & 28 \\
\hline Blatta orientalis : & 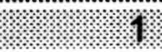 & 06 \\
\hline 8. & ? & 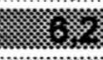 \\
\hline Calcarea fluonea : & the & 86 \\
\hline S6: & $x$ & 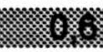 \\
\hline Erataegus ox yecantha & 1. & 0.6 \\
\hline 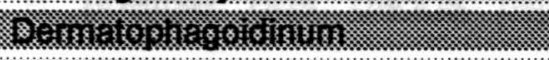 & 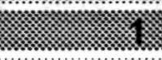 & 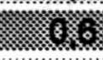 \\
\hline Folliculinum & 2. & $1 / 4$ \\
\hline 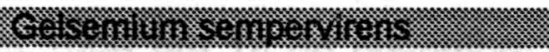 & $x$ & $x$ \\
\hline Kepar sulphurs : & צx. & 0.6 \\
\hline K) & ; & 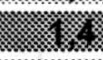 \\
\hline Ignatia amara : & 6 & 2.8 \\
\hline H & 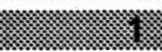 & 8 \\
\hline Lachesis : & 6 & $4.1 \%$ \\
\hline 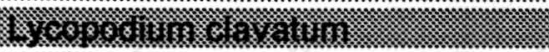 & (x) & 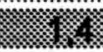 \\
\hline Mercunius solubilis & 2 & 1.4 \\
\hline (3) & $x$ & $\frac{1}{86}$ \\
\hline Natrum muinaticum & \% & 2,8 \\
\hline 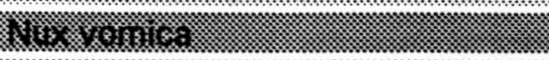 & 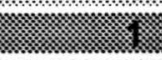 & 8 \\
\hline Passitora : & 槢 & $1 / 4$ \\
\hline 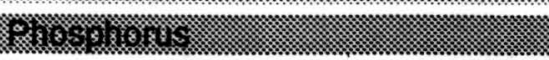 & 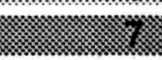 & 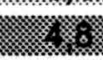 \\
\hline Phosphorio a od dun & th & 0.6 \\
\hline 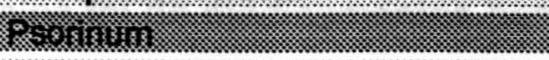 & 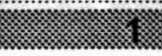 & 6 \\
\hline 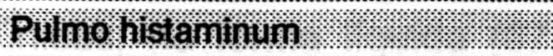 & x.6. & $8,4$. \\
\hline 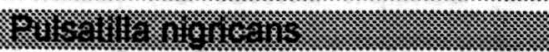 & 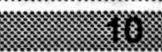 & 的汶: \\
\hline Rhus toxicorendron & 4.6 & 2.8 \\
\hline 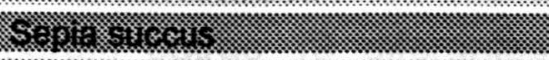 & (6) & $\frac{1}{6 x}$ \\
\hline Staphysagha & 4 & $21 \%$ \\
\hline Stz & 3 & 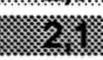 \\
\hline Streptococcinum & 11 & 06 \\
\hline (3) & x & (6) \\
\hline THeodo : : & 2. & 16/4 \\
\hline X) & (3) & (6) \\
\hline Veratrum album & .5 & .3 .4 \\
\hline 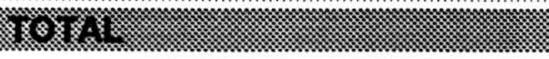 & 济 & (1) \\
\hline
\end{tabular}


TABELA 16: classificaçăo dos 10 medicamentos homeopáticos mais prescritos nas receitas aviadas pela farmácia homeopática Lírio D'Água, de 25 de maio de 1996 até 14 de novembro de 1997, provenientes do CTA do Posto de Saúde de ltú.

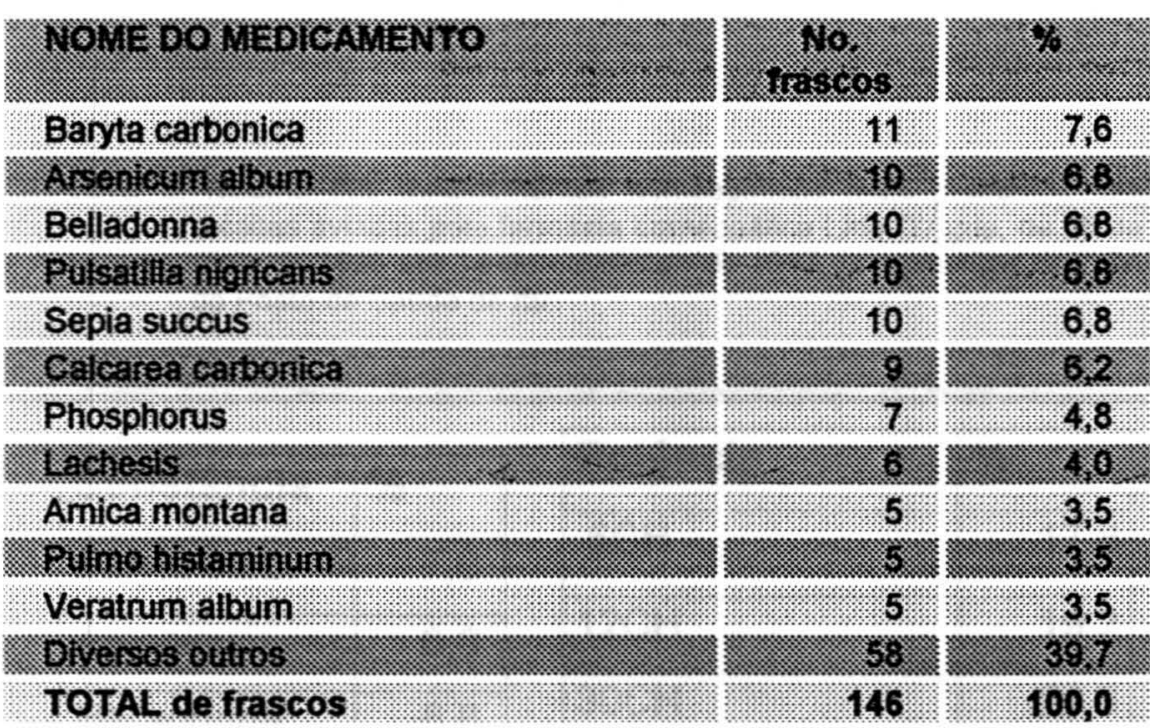

Após coleta e análise dos dados relativos aos medicamentos mais prescritos nas receitas aviadas pela farmácia homeopática Lírio D'Água, de 25 de maio de 1996 até 14 de novembro de 1997, provenientes do Centro de Terapia Alternativa do Posto de Saúde de Itú, podemos apresentar uma síntese dos mais prescritos.

\subsubsection{1 - Resumo dos medicamentos homeopáticos mais prescritos:}

Resumindo as observaçöes sobre estas prescriçőes, podemos afirmar que a maior parte delas foi de medicamentos homeopáticos preparados a partir de substâncias únicas, na forma líquida $(67,1 \%)$, sendo $92,5 \%$ tomadas em doses repetidas. As 4 principais potências representaram $69,2 \%$ das prescriçőes, porém outras 19 diferentes potências também apareceram nestas receitas.

Foram prescritas 43 diferentes substâncias. Em 146 frascos, 11 foi o número máximo de vezes que uma mesma substância foi prescrita. No total, 
11 substâncias foram responsáveis por $60,3 \%$ dos frascos prescritos. 0 Quadro 5 mostra uma síntese das prescrições mais freqüentes deste serviço.

QUADRO 5: resumo dos medicamentos homeopáticos mais prescritos nas receitas aviadas pela farmácia homeopática Lírio D'Água, de 25 de maio de 1996 até 14 de novembro de 1997, provenientes do CTA do Posto de Saúde de Itú.

\begin{tabular}{|c|c|c|c|}
\hline Substância & $\%$ & Potência & $\%$ \\
\hline Baryta carb. & 7,6 & $6 \mathrm{CH}$ & 17,8 \\
\hline Arsenicum & 6,8 & $12 \mathrm{CH}$ & 19,2 \\
\hline Belladonna & 6,8 & $30 \mathrm{CH}$ & 22,6 \\
\hline Pulsatilla & 6,8 & $200 \mathrm{CH}$ & 9,6 \\
\hline Sepia succus & 6,8 & diversas & 30,8 \\
\hline Calcarea car. & 6,2 & TOTAL & 100,0 \\
\hline Phosphorus & 4,8 & & \\
\hline Lachesis & 4,0 & Forma farmacêut. & $\%$ \\
\hline Arnica mont. & 3,5 & Líquida & 67,1 \\
\hline Pulmo hist. & 3,5 & Outras & 32,9 \\
\hline Veratrum & 3,5 & & \\
\hline diversas & 39,7 & Posologia & $\%$ \\
\hline \multirow[t]{2}{*}{ TOTAL } & \multirow[t]{2}{*}{60,3} & Dose repetida & 92,5 \\
\hline & & Dose única & 7,5 \\
\hline
\end{tabular}

\subsubsection{2 - Surgem novas dúvidas}

Observando que o medicamento mais prescrito, para os pacientes que aviaram suas prescriçōes na Farmácia Lírio D'Água, foi Baryta carbonica, e sabendo que este é um medicamento pouco usual, deduzimos que os dados 
encontrados podiam não ser representativos para o universo dos pacientes atendidos pelo serviço médico homeopático do Centro de Saúde de Itú. Considerando que todas as receitas aviadas gratuitamente naquela Farmácia eram para pacientes carentes, pudemos perceber que os 11 frascos de Baryta carbonica prescritos em diferentes receitas, foram, na verdade, aviados para apenas 3 pessoas, ainda que seus nomes apareçam anotados de forma diferente.

Esta repetição pode ser explicada exatamente porque sempre os mesmos pacientes carentes dirigiam-se à mesma farmácia e tinham seus medicamentos aviados e anotados. Caso estes individuos fossem pacientes assíduos no serviço médico, seus medicamentos seriam responsáveis por uma porcentagem relativamente grande de indicação daquelas substâncias. Se a farmácia atendesse e anotasse indistintamente as prescrições aviadas para todos os pacientes, provavelmente esta concentração de freqüência de um medicamento geralmente pouco utilizado não ocorreria.

Para testar esta hipótese foi necessário voltar ao Posto de Saúde de ltú, e, a partir das informações contidas nas fichas dos pacientes, realizar uma amostragem do universo total.

\subsection{2 - Dados das fichas clínicas}

Quando da visita ao serviço do CTA de ltú, foram encontradas no arquivo um total de 2040 fichas clínicas. Tendo que optar, rapidamente, por um critério de amostragem, decidiu-se tomar 1 ficha em cada 20, anotando o nome do paciente, sexo, idade, data das consultas realizadas e medicamentos prescritos. Desta forma foram registrados os dados dos pacientes da ficha número 1 , número 20 , número 40 , etc., e assim sucessivamente. Caso uma das fichas pré-determinadas não estivesse presente no fichário, ou nela não houvesse prescrição de medicamentos 
homeopáticos, passava-se para a de número seguinte. Em alguns casos foi difícil compreender a letra do médico ou a prescrição feita.

Nas 100 fichas clínicas estudadas como amostra, foram prescritos um total de 802 frascos de medicamentos, sendo 692 deles de substâncias dinamizadas $(86,8 \%)$. Quatro prescriçőes foram apenas parcialmente identificadas, portanto, para dar mais precisão aos cálculos, vamos considerar como 692 frascos de medicamentos dinamizados (Tabela 17).

\section{TABELA 17: classificaçăo das prescriçőes segundo os procedimentos provenientes do estudo das fichas clinicas dos pacientes atendidos no CTA do Posto de Saúde de ltú}

\begin{tabular}{|c|c|c|}
\hline 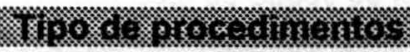 & I & $\%$ \\
\hline Substancias oinamizadas & 692 & 86.3 \\
\hline 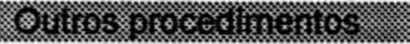 & 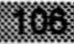 & 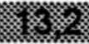 \\
\hline Năo ldentilicadas: & 4 & $0.5 \times$ \\
\hline$(x+1,1$ & 806 & 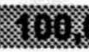 \\
\hline
\end{tabular}

Entre todos os atendimentos, foram utilizados 107 diferentes procedimentos que incluíram desde medicamentos homeopáticos dinamizados até a indicaçăo de conduta expectante, sem administraçăo de medicamento algum. Deste total, os medicamentos homeopáticos responderam por $86,9 \%$

TABELA 18: classificaçăo dos diferentes tipos de procedimentos provenientes do estudo das fichas clínicas dos pacientes atendidos no CTA do Posto de Saúde de itú.

\begin{tabular}{|c|c|c|}
\hline 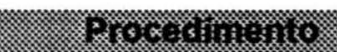 & $r \times$ & 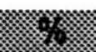 \\
\hline Essencias forais. & 30 & 286 \\
\hline ; & 86: & 202 \\
\hline Creme & 15 & $1 / 4 \times 3$ \\
\hline 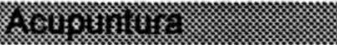 & 9. & 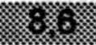 \\
\hline Alopatia . & 8 & 6 \\
\hline es: & 2. & 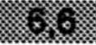 \\
\hline 14 & 6 & 57 \\
\hline Y & : & six: \\
\hline Pomada : & 4 & 88 \\
\hline soge & 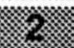 & $1.8:$ \\
\hline Gliceroleo : : & 数 & 18 \\
\hline 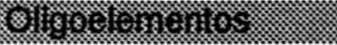 & $=$ & 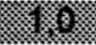 \\
\hline Sabonete: & 1 & 1.0 \\
\hline sin & $=$ & 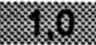 \\
\hline TOTAL. & 106 & 1000 \\
\hline
\end{tabular}


dos procedimentos, com a prescriçăo de 93 diferentes substâncias. A distribuiçăo de procedimentos năo homeopáticos pode ser verificada na TABELA 18 da página anterior, onde pode-se observar que as essências florais foram as mais utilizadas, representando $28,6 \%$ das opçős utilizadas.

Entre as substâncias dinamizadas, os 10 medicamentos mais prescritos podem ser observados na TABELA 19 abaixo:

\begin{tabular}{|c|c|c|}
\hline 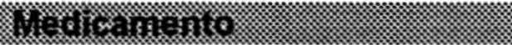 & 7 & $2 x$ \\
\hline Natrum muratieum & 62 & 980 \\
\hline 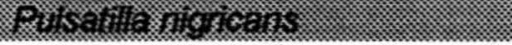 & 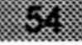 & (3) \\
\hline Lachesis : & 52. & 7.5 \\
\hline in & 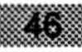 & $x$ \\
\hline Nox vomiad: : & 39 . & $5 \%$ \\
\hline Sorath ainsara & 32 & 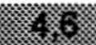 \\
\hline Lycopodium clavatum & 29 & 42. \\
\hline 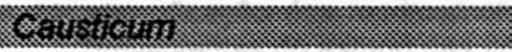 & 28 & 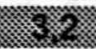 \\
\hline Sulphur : & 22. & 3.2. \\
\hline 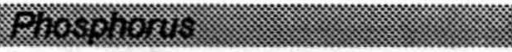 & 18 & 2 \\
\hline Outros 76 diversos & 315 & 45,6 \\
\hline $28 x+1$ & $60 y$ & 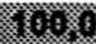 \\
\hline
\end{tabular}

Em relação às potências dos medicamentos dinamizados prescritos, 7 delas $(16,4 \%)$ foram escolhidas para $76,2 \%$ do total de prescriçōes. No total foram prescritas 41 diferentes potências, sendo 30 delas centesimais (de C3 a C200.000), 3 decimais (D1 a D3) e 8 LM (de LM4 a LM11) (TABELA 20). 
TABELA 20: classificaçăo dos medicamentos homeopáticos, quanto à potência, provenientes do estudo das fichas clínicas dos pacientes atendidos no CTA do Posto de Saúde de Itú.

\begin{tabular}{|c|c|c|}
\hline 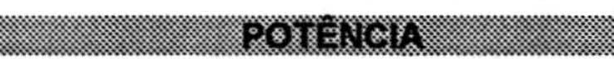 & $8 \%$ & *. \\
\hline 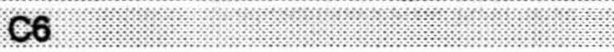 & 115 & 16.6 \\
\hline (ez; & $2 \%$ & $(x, 2=$ \\
\hline 012 & 150 & 21,7 \\
\hline (E. & 28 & 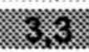 \\
\hline 030 & 122 & 17.7 \\
\hline 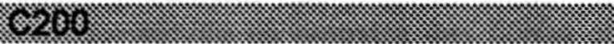 & $65 \times$ & 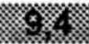 \\
\hline (2: & 20 & 2,9 \\
\hline 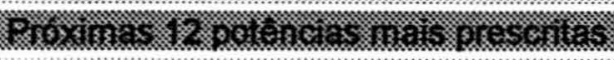 & 18 & 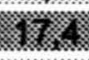 \\
\hline Todas as outras poténcias & 51 & 7.4 . \\
\hline 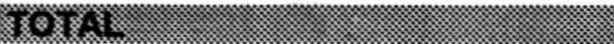 & 698. & 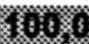 \\
\hline
\end{tabular}

Em relação à escala (ou proporção) de dinamização, a quase totalidade dos medicamentos foram prescritos na centesimal $(96,7 \%)$, conforme pode ser verificado adiante na TABELA 21.

\footnotetext{
TABELA 21: classificaçăo dos medicamentos homeopáticos, quanto à escala, provenientes do estudo das fichas clínicas dos pacientes atendidos no CTA do Posto de Saúde de Itú.
}

\begin{tabular}{|c|c|c|}
\hline 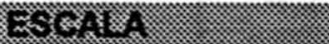 & 8 & * \\
\hline Centesimal & 669 & 96.7 \\
\hline 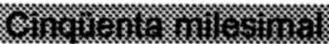 & 28 & $=2$ \\
\hline Decimal & 3 & 0.4 \\
\hline 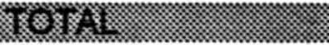 & 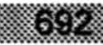 & 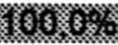 \\
\hline
\end{tabular}

As informaçōes relativas à forma farmacêutica e dose única ou repetida năo foram na maioria das vezes anotadas nas fichas, tornando-se inválidas para efeito de comparação.

\subsubsection{1 - Resumo dos medicamentos homeopáticos mais prescritos:}

Uma síntese dos medicamentos mais prescritos para os pacientes atendidos 
no serviço de Itú, segundo estudo de uma amostra das fichas clínicas, mostra as 10 substâncias mais prescritas, assim como as 5 diferentes potências que foram responsáveis por $70 \%$ das prescrições, quase todas na escala centesimal. pode ser verificada em seguida, no QUADRO 6.

QUADRO 6: resumo dos medicamentos homeopáticos mais prescritos em estudo de amostra das fichas clínicas provenientes de pacientes atendidos no CTA do Posto de Saúde de Itú.

\begin{tabular}{|c|c|c|c|}
\hline \multirow{2}{*}{$\begin{array}{l}\text { Medicament } \\
0\end{array}$} & \multirow[t]{2}{*}{$\%$} & Potência & $\%$ \\
\hline & & $6 \mathrm{CH}$ & 16,7 \\
\hline Natrum mur. & 9,0 & $7 \mathrm{CH}$ & 4,2 \\
\hline Pulsatilla & 7,8 & $12 \mathrm{CH}$ & 21,8 \\
\hline Lachesis & 7,5 & $30 \mathrm{CH}$ & 17,9 \\
\hline Arsenicum & 6,6 & $200 \mathrm{CH}$ & 9,4 \\
\hline Nux vomica & 5,6 & \begin{tabular}{|l|} 
Diversas \\
\end{tabular} & 30,0 \\
\hline Ignatia amara & 4,6 & TOTAL & 70,0 \\
\hline Lycopodium & 4,2 & & \\
\hline Causticum & 3,2 & Escala & $\%$ \\
\hline Sulphur & 3,2 & Centesimais & 96,8 \\
\hline Phosphorus & 2,7 & Outras & 3,2 \\
\hline TOTAI & $10 \cap n$ & & \\
\hline
\end{tabular}

\subsection{3 - Comparaçăo entre os resultados da Farmácia e das fichas} clínicas.

A comparação entre os resultados obtidos entre os 2 grupos de dados coletados, isto é, cópia das prescrições aviadas para pacientes carentes na Farmácia Lírio D'Água e amostra das fichas clínicas de todos os pacientes atendidos no Centro de Saúde, pode ser vista no QUADRO 7 a seguir. 
QUADRO 7: comparaçăo entre os dados dos 10 medicamentos mais prescritos, da farmácia homeopática Lírio D'Água e os do estudo de amostra das fichas clínicas provenientes de pacientes atendidos no CTA do Posto de Saúde de ltú.

\begin{tabular}{|l|c|c|}
\hline Medicamento & Farm. \% & CTA \% \\
\hline Baryta carb. & 7,6 & - \\
\hline Arsenicum & 6,9 & 6,6 \\
\hline Belladonna & 6,9 & - \\
\hline Pulsatilla & 6,9 & 7,8 \\
\hline Sepia succus & 6,9 & - \\
\hline Calcarea carb. & 6,2 & - \\
\hline Phosphorus & 4,8 & 2,7 \\
\hline Lachesis & 4,1 & 7,5 \\
\hline Amica mont. & 3,5 & - \\
\hline Pulmo histam. & 3,5 & - \\
\hline Natrum mur. & - & 9,0 \\
\hline Nux vomica & - & 5,6 \\
\hline Ignatia amara & - & 4,6 \\
\hline Lycopodium & - & 4,2 \\
\hline Causticum & - & 3,2 \\
\hline Sulphur & - & 3,2 \\
\hline Veratrum & 3,5 & - \\
\hline Diversos & 29,2 & 45,6 \\
\hline TOTAL & 100,0 & 100,0 \\
\hline
\end{tabular}

\begin{tabular}{|l|r|r|}
\hline Poténcia & Farm. \% & \multicolumn{1}{|c|}{ CTA $\%$} \\
\hline $6 \mathrm{CH}$ & 17,8 & 16,7 \\
\hline $9 \mathrm{CH}$ & 1,9 & 1,7 \\
\hline $12 \mathrm{CH}$ & 19,2 & 21,8 \\
\hline $18 \mathrm{CH}$ & 4,5 & 3,3 \\
\hline $30 \mathrm{CH}$ & 22,6 & 17,9 \\
\hline Diversas & 34,0 & 38,6 \\
\hline TOTAL & 100,0 & 100,0 \\
\hline
\end{tabular}

\begin{tabular}{|c|c|c|}
\hline Forma farm. & Farm. \% & CTA \% \\
\hline Liquido & 67,1 & - \\
\hline Outras & 32,9 & - \\
\hline
\end{tabular}

\begin{tabular}{|c|c|c|}
\hline Posologia & Farm. \% & CTA \% \\
\hline Dose repetida & 92,5 & - \\
\hline Dose única & 7,5 & - \\
\hline
\end{tabular}

\begin{tabular}{|c|c|c|}
\hline \multicolumn{3}{|c|}{ Escala } \\
\hline Escala & Farm. \% & CTA \% \\
\hline Centesimal & 96.8 & - \\
\hline Outras & 3,2 & - \\
\hline
\end{tabular}

Quando comparamos o resumo dos dados da farmácia e das fichas clínicas, relativos aos pacientes atendidos no serviço de Itú, percebemos que existe concordância entre apenas 4 substanncias dentre as 10 mais prescritas, confirmando a idéia inicial de que as prescriçōes analisadas provenientes das anotações da farmácia eram específicas de alguns poucos pacientes. Portanto, os dados que melhor representam a população local são os provenientes da análise das fichas clínicas. 


\section{3 - O atendimento homeopático na Policlínica de Brumadinho:}

Brumadinho é uma cidade pertencente à Grande Belo Horizonte, Minas Gerais. Em 1991 o atendimento clínico ambulatorial do Centro de Saúde da cidade era realizado por 4 médicos, sendo 3 deles, por acaso, especializados em Homeopatia. Com o apoio da Secretaria de Saúde, estes médicos decidiram elaborar o projeto de implantação do ambulatório de Homeopatia no Serviço Público de Saúde de Brumadinho.

Este serviço público não foi entrevistado pessoalmente para elaboração desta pesquisa, Os dados foram obtidos a partir de FROEDE, "A Homeopatia no Serviço de Saúde Pública de Brumadinho". Xerocópias do Livro de Registro do Receituário da Farmácia de Manipulação Homeopática do Centro de Saúde foram enviadas por correio e partir deste registro, foram retirados os dados sobre medicamentos prescritos no serviço ${ }^{(65)}$.

Segundo FROEDE, inicialmente, o atendimento homeopático era feito no final dos turnos de atendimento de clínica médica, de acordo com a disponibilidade do médico e do paciente. Os médicos sugeriam aos pacientes o tratamento homeopático e, caso o aceitassem, eram agendadas consultas homeopáticas. Entretanto, isto gerou uma série de dificuldades: o médico deveria fazer o seu atendimento clínico normal e depois fazer o atendimento homeopático; não havia um critério de seleção dos pacientes para as consultas homeopáticas e, na maioria das vezes, eram selecionados aqueles que, devido a riqueza de sintomas, pareciam ter uma abordagem mais fácil. Além disto, não havia participação ativa da Secretaria de Saúde, que apenas permitia a consulta homeopática dentro do Centro de Saúde, com uso do seu espaço físico, mas sem qualquer outro meio de ajuda. Os medicamentos homeopáticos eram doados por farmácias de Belo Horizonte ou pelos próprios médicos, uma vez que não havia farmácia homeopática na cidade ${ }^{(65)}$. 
O projeto previa que os recursos humanos e a área física, incluindo móveis e utensílios, seriam aqueles já disponíveis no Centro de Saúde. Seria necessária a instalação de uma Farmácia de Manipulação Homeopática no local, uma vez que os medicamentos doados não dariam conta de satisfazer a demanda e caracterizar-se-iam como a face mais amadora do projeto, que tinha tudo para consolidar-se. O investimento seria apenas a compra de vidraria e de 178 matrizes de medicamentos na forma líquida e na dinamização $6 \mathrm{CH}$ e $30 \mathrm{CH}$, algumas nas FC200 e outros também na FC1000 (as últimas obtidas através do método de Fluxo Contínuo).

O projeto foi aprovado e em julho de 1991 a farmácia homeopática foi instalada no mesmo espaço físico da farmácia alopática, no Posto de Saúde. Os medicamentos eram preparados pelos próprios médicos e veiculados na forma de glóbulos.

A contratação de um farmacêutico durante 20 horas semanais (que por ocasião da entrevista telefônica trabalhava 30 horas por semana), possibilitou a manipulação homeopática, fitoterápica (de pomadas, xaropes, etc.) e de produtos químicos e farmacêuticos para os outros setores, como para a Enfermaria, Pediatria e Ginecologia. Com o aumento da demanda, foi contratada uma auxiliar, com carga horária semanal de 40 horas.

Em maio de 1993 foi criado um ambulatório separado da clínica médica para a Homeopatia. $\mathrm{O}$ atendimento era realizado por duas médicas, de $2 \mathrm{a}$. a $5 \mathrm{a}$. feira, no turno da tarde, quando eram atendidos, em média, de 4 a 6 pacientes. Um ano depois foi inaugurado o Centro Terapêutico Reencontro, no prédio onde anteriormente funcionava o Posto de Atendimento Médico (PAM) do INAMPS, abrigando os ambulatórios de Homeopatia, Acupuntura, Fonoaudiologia e a Farmácia de Manipulação. Posteriormente estes serviços foram transferidos para a Policlínica, o que trouxe algumas desvantagens, porém também um maior entrosamento com outros 
profissionais da saúde e maior facilidade de encaminhamentos e agendamento de consultas. Durante este período, 2 médicos saíram do atendimento.

A avaliação do serviço detectou os seguintes problemas, segundo FROEDE (65).

1. inexistência de um sistema de coleta de dados que auxiliasse na avaliação, na verificação do perfil da demanda dos pacientes, patologias predominantes e duração do tratamento.

2. inexistência de grupos de estudo de casos clínicos e de avaliação das atividades do serviço, com reuniões durante o horário de trabalho.

3. falta de divulgação para a população e intercâmbio com outros profissionais da equipe de saúde.

4. conhecimento insuficiente do perfil da demanda.

Observou-se que passaram pela consulta durante estes 5 anos, cerca de 800 pacientes, na maioria mulheres e crianças, especialmente com processo alérgicos, bronquites e manifestações psicossomáticas. A porcentagem de retornos era muito variável e dependia da patologia, da ansiedade do paciente e/ou do médico, do rápido acerto da medicação. Após a estabilização do paciente, ele retornava quando julgava necessário. Quando as receitas médicas não eram aviadas logo após a consulta, muitos pacientes não retornavam para buscar os medicamentos.

Foi instituída uma pré-consulta obrigatória, feita pela farmacêutica, na forma de aula/debate, para aumentar a confiança e a segurança, e esclarecer 
dúvidas. Nesta oportunidade era possivel constatar que a maior parte dos pacientes desconhecia como era o tratamento homeopático. Geralmente sofrendo de patologias crônicas, chegavam ao serviço recomendados por alguém que obteve sucesso no tratamento. Suas dúvidas mais comuns eram sobre como tomar o medicamento, que cuidados eram requeridos, a possibilidade de ocorrência de efeitos colaterais, o que contar ao médico na primeira consulta e insegurança sobre eficácia do tratamento.

O agendamento mensal das consultas também era feito na farmácia. Após a implantação da pré-consulta e deste agendamento, as desistências e as faltas diminuiram.

O atendimento era realizado por 3 médicas cujas cargas horárias totalizavam 76 horas mensais, divididas em turnos de 4 horas, de 2a. a 5a. feira. Por turno, eram realizadas uma 1a. consulta, 3 a 4 retornos, além de casos urgentes.

Os retornos variavam com o médico e o paciente, ocorrendo entre 30 a 40 dias após a consulta.

Os medicamentos homeopáticos eram manipulados apenas com receita médica e aviados na forma de glóbulos ou líquidos, principalmente nas potências $6 \mathrm{CH}, 30 \mathrm{CH}$ e $\mathrm{FC} 200$. As dinamizaçōes intermediárias eram estocadas em álcool a $70 \%$ para sua maior conservação, já que notava-se um crescimento na solicitação de potências intermediárias.

Alguns medicamentos mais prescritos já ficavam estocados prontos, como Arnica montana, Hamamelis virginiana, Sulphur, Belladonna, Pulsatilla nigricans, Natrum muriaticum, Phosphorus e Silicea, nas potências $6 \mathrm{CH}$ e $30 \mathrm{CH}$. Quando o serviço não tinha possibilidade de atender à prescrição, 0 paciente era orientado a aviar a receita em Belo Horizonte. Na ausência da 
farmacêutica ou de sua auxiliar, o próprio médico estava orientado para fazer o preparo.

O Secretário Municipal de Saúde anterior era médico homeopata e apoiou o atendimento de Homeopatia e Fitoterapia no Centro de Saúde. Com o final de sua gestão, o serviço de Homeopatia foi fechado, pois foi considerado mais caro que o tradicional, uma vez que atende a um menor número de pacientes. A Farmácia de Manipulação continuava produzindo pomadas, xaropes, produtos para o hospital e medicamentos dermatológicos, e manipulando os medicamentos homeopáticos prescritos. A Farmácia, por ter as matérias primas, faz este aviamento gratuitamente, mesmo para alguns provenientes de consultas particulares.

Com as alterações, a comunidade ficou revoltada e tentou organizar-se, através do encaminhamento de abaixo-assinados, mas nada acabou acontecendo. Os médicos foram demitidos ou forçados a demitir-se, uma vez que não existia mais marcação de consultas homeopáticas.

O serviço de atendimento médico homeopático de Brumadinho durou 2 anos. A farmacêutica contratada para desenvolver a farmácia homeopática, continua trabalhando no local, com esperanças de que um dia o serviço de atendimento médico homeopático volte a Brumadinho. A atual gestão privilegiou a assistência farmacêutica e melhorou as instalações da farmácia, que atendem a muito pedidos do Hospital Municipal João Fernandes do Carmo. Ambientes condicionados e separados destinam-se à manipulação de diferentes formas farmacêuticas.

\subsection{1 - Dados obtidos do Caderno de Registro de Receituário}

Recebemos cópias do Caderno de Registro de Receituário, onde eram anotadas todas as prescrições aviadas, provenientes do atendimento de 
578 pacientes, realizado por 11 diferentes médicos.

No total foram prescritas 99 diferentes substâncias, seja como medicamento homeopático isolado, como complexo, em xarope, cremes, pomadas, etc.

Houve a prescriçăo de 1360 frascos de medicamentos, sendo 74,9\% (1018) destes, medicamentos homeopáticos dinamizados. Entre estes dinamizados, 95 frascos $(7,0 \%)$ foram prescritos sob a forma de complexos, sendo 59 deles descritos como "Soluçăo Homeopática para Cólicas", fórmula usual naquele serviço, não indicada através de seus componentes, mas pelo nome fantasia. Considerando apenas os medicamentos homeopáticos dinamizados isolados (năo complexos), foram aviados 923 frascos. Outros foram Fitoterápicos e 16 frascos de medicamentos diversos. Na TABELA 22 pode-se verificar a distribuição destas prescriçōes.

TABELA 22: classificaçăo dos medicamentos, segundo cópia do Caderno de
Registro de Receituário, aviados na Farmácia de Manipulaçăo
Homeopática da Policlínica de Brumadinho.

Foram classificados como Fitoterápicos 170 frascos de tinturas, 66 frascos de xaropes, 1 de óleo de germe de trigo, 61 pomadas, 12 de géis, 5 de cremes, 9 de óvulos vaginais e 3 frascos de sabão de ervas.

Quanto aos 170 frascos de tinturas, 35,9\% foram de Tintura de Própolis, seguido de $12,4 \%$ de Alcachofra, que somam praticamente metade das prescrições deste tipo. As restantes foram representadas por outras 13 tinturas diferentes, conforme pode ser verificado na TABELA 23. 
TABELA 23: distribuiçăo das tinturas, segundo cópia do Caderno de Registro de Receituário, aviadas pela Farmácia de Manipulaçăo Homeopática da Policlínica de Brumadinho.

\begin{tabular}{|c|c|c|}
\hline 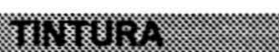 & $\pi$ & 12 \\
\hline Propolis & 61 & 35.9 \\
\hline 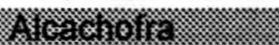 & 8 & 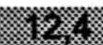 \\
\hline Salvia : & 15 & 8.8 \\
\hline 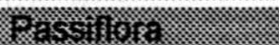 & 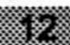 & 7 \\
\hline Suaco & 111 & 6.5 \\
\hline X & $x 8$ & 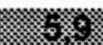 \\
\hline Avera & 9 & 52 \\
\hline Soxo: & : & is \\
\hline Calendua & 禁 & $4.1 \%$ \\
\hline (X) & ; & ; \\
\hline Thuya : & 5 & $20 \%$ \\
\hline (6) & 2 & $(x)$ \\
\hline Echinacea & 2 & 12 \\
\hline 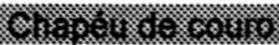 & 桑 & 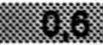 \\
\hline Malva & 1 & 0.6 \\
\hline 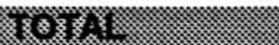 & 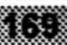 & 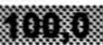 \\
\hline
\end{tabular}

Foram prescritos 61 frascos de pomadas, sendo que as de Arnica, Calêndula e Própolis perfazem 64,5\% das prescriçőes (TABELA 24).

TABELA 24: distribuiçăo das pomadas, segundo cópia do Caderno de Registro de Receituário, aviadas pela Farmácia de Manipulaçăo Homeopatica da Policlínica de Brumadinho.

\begin{tabular}{|c|c|c|}
\hline 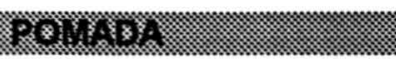 & $x$ & 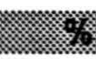 \\
\hline Amica : : & 17. & 27.9 \\
\hline 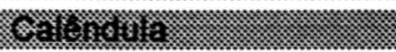 & $x$ & 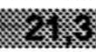 \\
\hline Propolis: & 10 & 164 \\
\hline 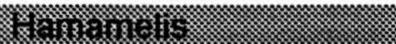 & 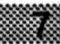 & 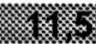 \\
\hline Caletadiua e Rropolis & 6 & 98 \\
\hline Sow & 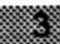 & 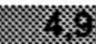 \\
\hline Ealendula e Yamamelis & 2 & 3.3 \\
\hline 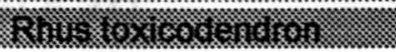 & $x$ & $x$ \\
\hline Thuya : : : : : : : : & . & 16 \\
\hline$m \times x$ & $x$ & 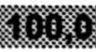 \\
\hline
\end{tabular}

Em relação aos xaropes, foram prescritos 66 frascos, sendo 47 deles (71,2\%), Xarope de Guaco com Própolis. Além deste, foram prescritos outros 5 xaropes, todos contendo Guaco ou Própolis, mais algum outro 
componente, conforme pode ser verificado na TABELA 25.

TABELA 25: distribuição dos xaropes, segundo cópia do Caderno de Registro de Receituário, aviados pela Farmácia de Manipulaçăo Homeopática da Policlínica de Brumadinho.

\begin{tabular}{|c|c|c|}
\hline 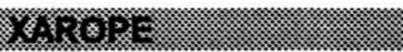 & 7 & 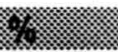 \\
\hline Guaco e Propolis & 47 & 7122 \\
\hline 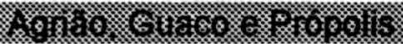 & : & 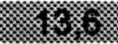 \\
\hline Guaco & 5 & $1 \% 6$. \\
\hline \% & 2 & 83 \\
\hline Guaco, mel o Propolis. & 2 & 3.0 \\
\hline 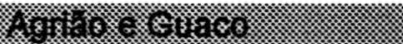 & $\mathbb{x}$ & 8.62 \\
\hline TOTAL : : & 66 & 1000 \\
\hline
\end{tabular}

Quanto aos géis, foram encontradas 12 prescrições, metade delas de Calêndula, conforme pode ser verificado na TABELA 26.
TABELA 26: distribuiçåo dos géis, segundo cópia do Caderno de Registro de Receituário, aviados pela Farmácia de Manipulaçăo Homeopática da Policlínica de Brumadinho.

\begin{tabular}{|c|c|c|}
\hline$e^{2}=1$ & k) & w \\
\hline Calenduta. & 6 & 50.0 \\
\hline 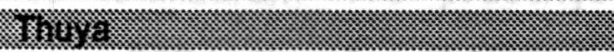 & 然 & $8 \times$ \\
\hline Amioa & 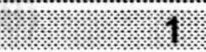 & 8.3 \\
\hline Ack & 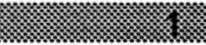 & 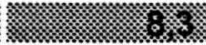 \\
\hline Calendula e ramaneis : & x & 8.3 \\
\hline (8) & 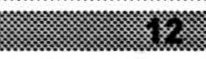 & 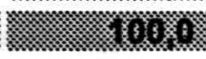 \\
\hline
\end{tabular}

Em relaçăo aos cremes, foram prescritos 8 frascos de 6 diferentes tipos. Embora tenham sido descritos como produtos fitoterápicos, os cremes Hidratante, Calicida e para Escabiose certamente contém outros princípios ativos (TABELA 27). 
TABELA 27: distribuiçăo dos cremes, segundo cópia do Caderno de Registro de Receituário, aviados pela Farmácia de Manipulaçăo Homeopática da Policlínica de Brumadinho.

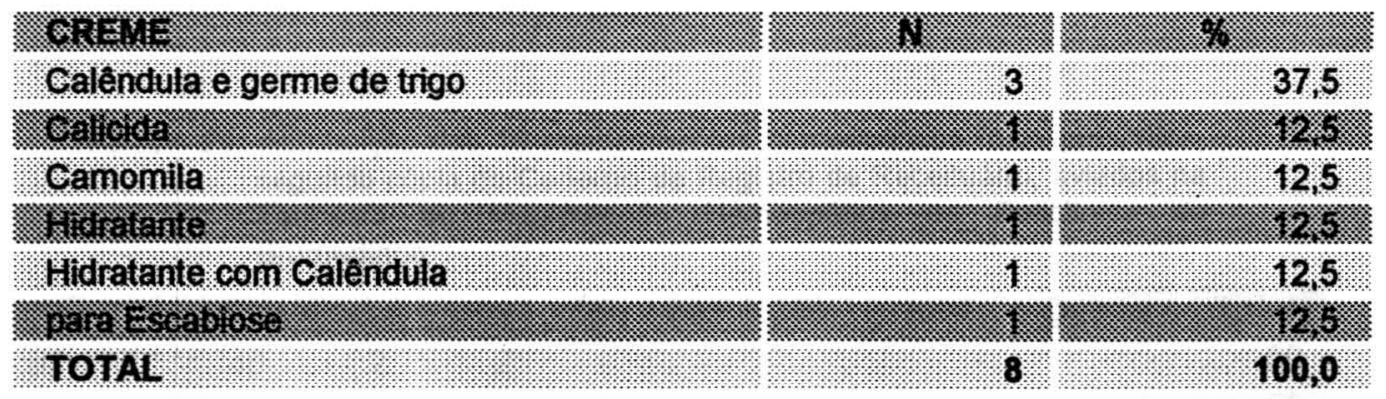

Os medicamentos diversos foram 5 frascos de Pasta d'água, 4 de Solução contra Micose e 2 de Glicerina.

Considerando agora apenas os medicamentos dinamizados, verificamos que os mais prescritos foram: Nux vomica, Arnica montana, Pulsatilla nigricans, Ignatia amara, Lycopodium clavatum, Arsenicum album, Natrum muriaticum, Sulphur, Thuya occidentalis e Phosphorus. Estes 10 medicamentos totalizaram 418 prescriçőes $(43,1 \%)$, sendo 89 outros responsáveis por 552 indicações (TABELA 28).

TABELA 28: distribuiçăo das substâncias mais prescritas (incluindo aquelas em complexos), segundo cópia do Caderno de Registro de Receituário, aviadas na Farmácia de Manipulaçăo Homeopática da Policlínica de Brumadinho, MG.

\begin{tabular}{|c|c|c|}
\hline 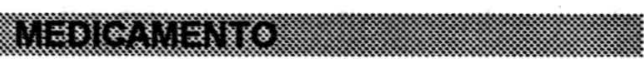 & is & $\%=$ \\
\hline Nox Vomica & 57. & 59 \\
\hline KM & $x$ & 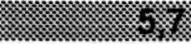 \\
\hline Pulsatilla nigricans & 52 & 54 \\
\hline Sis: & ; & 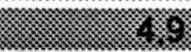 \\
\hline Leopodium clavalum & 46. & 47 \\
\hline r.m: & 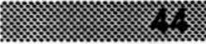 & 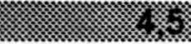 \\
\hline Natum mutraticum & 34. & 3.5 \\
\hline SW: & 新 & 的 \\
\hline Bubya occidentalis & 26 & 27 \\
\hline 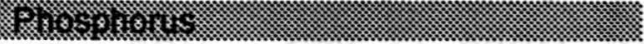 & $2 z^{2}$ & 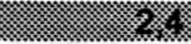 \\
\hline Buersos ( 89 substancis) & 552 & 568 \\
\hline (3) - & $8 \%$ & (x) \\
\hline
\end{tabular}


A distribuição dos medicamentos mais prescritos, em função de suas diferentes potências pode ser visto na TABELA 29.

TABELA 29: distribuiçăo dos 10 medicamentos homeopáticos mais prescritos, segundo cópia do Caderno de Registro de Receituário, aviados na Farmácia de Manipulaçăo Homeopática da Policlínica de Brumadinho.

\begin{tabular}{|c|c|c|c|c|c|c|c|c|c|}
\hline & (6. & 9 & 30 & 43 & 36 & 203 & 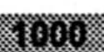 & 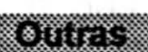 & (6. \\
\hline Amica & 46 & 2.2 & 2 & x & . & 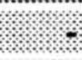 & 2.8. & 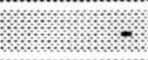 & 50 \\
\hline 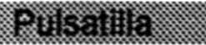 & $=4$ & (2) & 86 & s. & 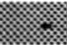 & 72 & (x) & 3. & 56 \\
\hline lgnatia & 2 & 5 & 17 & 3 & 4 & 4 & 8 & 4 & 47 \\
\hline 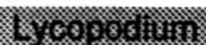 & 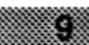 & 12 & 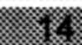 & 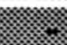 & . & 8 & $x$ & 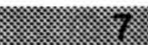 & 86 \\
\hline Arsenicum & 9 & 2. & 13 & 2. & 2. & 3 &. & 12 & 43 \\
\hline 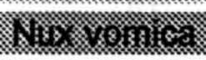 & (s) & $\%$ & 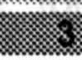 & 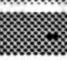 & 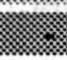 & 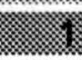 & 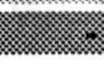 & 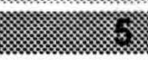 & 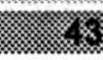 \\
\hline Natrum mur & 1 & 2 & 6 & 2 & 3. & 1 & 5 & 14 & 34 \\
\hline 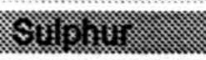 & 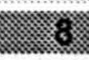 & 8 & 媇 & য & m & (x) & 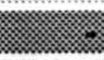 & 8 & 8 \\
\hline Thuya & 3 & 22 & 然 & x & - & 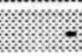 & - & $x$ & 26 \\
\hline 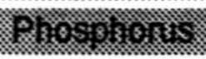 & . & 8 & $x$ & . & (1) & . & 2 & 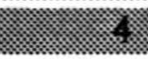 & 18 \\
\hline TOTA & 120 & 69 & 88 & 16 & 11 & 22 & 16 & 57 & 394 \\
\hline 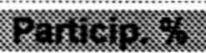 & 3635 & t. & $8 \times 1$ & (x) & 1): & 86 & $2 \times$ & 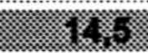 & 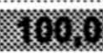 \\
\hline
\end{tabular}

Considerando apenas os 10 medicamentos mais prescritos e estudando-se as potências em que estes foram solicitados, percebe-se na última linha da TABELA 34 uma grande dispersão, com algum acúmulo na $6 \mathrm{CH}, 12 \mathrm{CH}$, $30 \mathrm{CH}, 40 \mathrm{CH}, \mathrm{C} 200$ e $\mathrm{C} 1000$. Considerando apenas estas 6 potências, englobamos $78,8 \%$ das prescriçōes totais. As outras potências diversas totalizam os $21,2 \%$ dos medicamentos restantes.

Outro ponto interessante é verificar que, apesar da potência $6 \mathrm{CH}$ ser a mais prescrita $(30,5 \%$ das prescriçöes entre os 10 medicamentos mais solicitados), isto não ocorre para todos os medicamentos. Por exemplo, tratando-se de Arnica montana, realmente $46 \%$ das vezes em que ela foi solicitada, foi na $6 \mathrm{CH}$, porém já para Ignatia amara, isto ocorreu apenas $2 \%$ das vezes em $6 \mathrm{CH}$ e $17 \%$ na $30 \mathrm{CH}$. Para Thuya occidentalis, $3 \%$ das prescriçőes foram na $6 \mathrm{CH}$ e $1 \%$ na $30 \mathrm{CH}$, enquanto que $22 \%$ das prescrições foram solicitadas na $12 \mathrm{CH}$. Quando consideramos Natrum 
muriaticum, notamos que existem indicaçōes em diversas poténcias, de $6 \mathrm{CH}$ até 1000. Devemos lembrar que Brumadinho contava com farmácia de manipulação homeopática local, o que possibilitava o atendimento de prescriçőes diversas. De qualquer forma os dados acima demonstram que, no preparo de listas de medicamentos homeopáticos mais prescritos, pode ser necessário, ao lado de informaçōes das substâncias e das potências mais solicitadas, cruzar estas informações.

Considerando apenas as prescrições acima, relativas aos 10 medicamentos mais prescritos quanto à forma farmacêutica, em $67 \%$ das vezes a prescriçăo foi de glóbulos, em $25 \%$ das vezes de líquidos e em $8 \%$ dos casos năo havia anotaçăo da forma farmacêutica que foi aviada. Dentre os glóbulos, $4 \%$ das anotaçōes faziam menção a dose única (TABELA 30).

TABELA 30: classificaçăo dos medicamentos homeopáticos, quanto à forma farmacêtuca, segundo cópia do Caderno de Registro de Receituário, aviados pela Farmácia de Manipulaçăo Homeopática da Policlínica de Brumadinho.

\begin{tabular}{|c|c|}
\hline 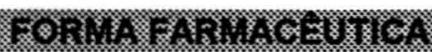 & 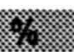 \\
\hline Globulos & 67. \\
\hline I & 85 \\
\hline Sem indicacto & 8 \\
\hline 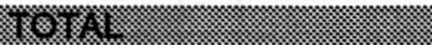 & 80 \\
\hline
\end{tabular}

Podemos verificar, em seguida, um resumo dos medicamentos mais prescritos na Policlínica de Brumadinho.

\subsubsection{1 - Resumo dos medicamentos homeopáticos mais prescritos:}

O QUADRO 8 na próxima página, mostra um resumo dos medicamentos homeopáticos mais prescritos na Policlínica de Brumadinho. 
QUADRO 8: resumo dos medicamentos homeopáticos mais prescritos na Policlinica de Brumadinho.

\begin{tabular}{|l|r|}
\hline Substância & \multicolumn{1}{|l|}{$\%$} \\
\hline Nux vomica & 5.9 \\
\hline Arnica montana & 5.7 \\
\hline Pulsatilla nigricans & 5.4 \\
\hline Ignatia amara & 4.9 \\
\hline Lycopodium clav. & 4.7 \\
\hline Arsenicum album & 4.5 \\
\hline Natrum muriaticum & 3.5 \\
\hline Sulphur & 3.5 \\
\hline Thuya occidentalis & 2.7 \\
\hline Phosphorus & 2.4 \\
\hline Outras & 39,2 \\
\hline TOTAL & 100,0 \\
\hline
\end{tabular}

\begin{tabular}{|l|r|}
\hline Potência & \multicolumn{1}{|l|}{$\%$} \\
\hline $6 \mathrm{CH}$ & 28.7 \\
\hline $12 \mathrm{CH}$ & 16.5 \\
\hline $30 \mathrm{CH}$ & 19.9 \\
\hline $40 \mathrm{CH}$ & 3.8 \\
\hline $\mathrm{C} 200$ & 5.2 \\
\hline $\mathrm{C} 1.000$ & 3.8 \\
\hline diversas & 22,1 \\
\hline TOTAL & $100,07$.
\end{tabular}

\begin{tabular}{|l|c|}
\hline Forma farmacéut. & $\%$ \\
\hline Glóbulos & 67.0 \\
\hline Outra & 33,0 \\
\hline
\end{tabular}

\begin{tabular}{|l|r|}
\hline \multicolumn{1}{|c|}{ Escala } & \multicolumn{1}{c|}{$\%$} \\
\hline Centesimal & 96.8 \\
\hline Outras & 3,2 \\
\hline
\end{tabular}

\begin{tabular}{|l|r|}
\hline Posologia & \multicolumn{1}{|l|}{$\%$} \\
\hline Dose repetida & 96.0 \\
\hline Dose única & 4,0 \\
\hline
\end{tabular}

\section{4 - O atendimento médico homeopático público em Santo Amaro} da Imperatriz:

A Homeopatia foi introduzida na rede do Serviço Público de Saúde, no Municipio de Santo Amaro da Imperatriz, com cerca de 20.000 habitantes, no estado de Santa Catarina, no ano de 1993, através do Serviço de Saúde do Escolar, mantido pelas Secretarias Municipais de Educação e Saúde. Em 
fevereiro de 1999 suas instalações foram ampliadas.

A população era constituída em grande parte por famílias de agricultores, e as crianças tinham uma saúde satisfatória e bom estado nutricional. As principais intercorrências eram relativas a amigdalites, otites e bronquites.

O serviço conta com manipulação de medicamentos realizado por farmacêutica contratada, e um médico homeopata, que passava 1 manhã por semana nas escolas e 2 dias na Unidade Sanitária "Prefeito José Kherig". Este proferia palestras nas 26 escolas municipais e estaduais de 10. grau, esclarecendo aos pais e alunos, desde o pré-escolar até a $8 \mathrm{a}$. série do 10. grau, a respeito do tratamento médico homeopático e enfatizando a promoção de saúde através da melhora na alimentação, higiene e no relacionamento familiar e estudantil. Após as palestras era feita a avaliação das condiçōes básicas de saúde de cada estudante e quando houvesse necessidade de tratamento médico, existia o encaminhamento para o Posto de Saúde Municipal.

No Posto de Saúde eram realizadas 3 primeiras consultas e 8 retornos em 2 manhãs da semana. A primeira consulta tinha a duração média de 45 minutos; os retornos, 15 minutos.

O atendimento podia ser ampliado para qualquer integrante da comunidade, uma vez que adultos passaram a interessar-se pelo tratamento médico homeopático após observar os bons resultados obtidos com suas crianças.

Era utilizado o tratamento médico homeopático unicista e indicado sempre o medicamento na escala cinqüenta milesimal, iniciado com a segunda potência (LM2), na forma líquida, administrando o medicamento sob a forma de 5 gotas, 3 vezes ao dia. Caso a evoluçăo do paciente fosse boa, ele era orientado para tomar a medicamento até o final do frasco, ou seja, por cerca 
de 30 a 40 dias, só retornando após o término. Caso contrário, o paciente deveria interromper a ingestão do medicamento e procurar novamente o atendimento médico, pessoalmente, ou por telefone. No caso de quadros agudos, a orientaçăo era tomar 3 gotas do medicamento de 5 em 5 minutos, durante 30 minutos; em seguida, de 10 em 10 minutos, até completar 1 hora, se necessário, parando então por 1 hora, para observação. Se o medicamento estivesse correto, deveria haver melhora. Às vezes uma potência era mantida por até mesmo mais que 30 dias, variando apenas a posologia: 5 gotas 3 vezes ao dia e, em seguida, 10 gotas 2 vezes ao dia. Alguns pacientes paravam de tomar o medicamento quando seus sintomas melhoravam, voltando a procurar o atendimento médico somente 1 ou 2 anos depois.

Houve uma tentativa de utilizar frascos com $120 \mathrm{ml}$ de medicação, administrando as doses em colheradas, porém observou-se maior dificuldade para os pacientes. Passou-se então a diluir 1 microglóbulo do medicamento em $120 \mathrm{ml}$ de solução hdroalcoólica a $20 \%$, aviando-se $30 \mathrm{ml}$ para cada paciente. $O$ restante era guardado para ser utilizado em uma próxima prescrição. Como a validade desta solução era de 6 meses, às vezes havia perda da solução inicial.

Optou-se pela escala cinqüenta milesimal por sua rápida e segura resposta terapêutica, tanto em quadros clínicos agudos ou crônicos, como por sua praticidade na manipulação e armazenamento, associados ao baixo custo de sua produção.

Para otimizar ainda mais o custo, era solicitado que os pacientes retornassem os frascos de medicamentos vazios, para serem reutilizados após fervura durante 30 a 60 minutos, permanência em álcool a $70 \%$ durante 1 a 2 dias, seguida de nova fervura e secagem em estufa a $60^{\circ} \mathrm{C}$. Quando havia devolução de cânulas, elas eram reservadas para 
medicamentos prescritos para bebês, pela facilidade de uso para esta faixa etária.

O coordenador considerava muito mais fácil utilizar a escala cinqüenta milesimal para o atendimento em Saúde Pública. Caso um segundo médico consultante fosse contratado, e este desejasse utilizar medicamentos na escala centesimal, seria necessária sua aquisição, provavelmente em diversas potências, como $6 \mathrm{CH}, 12 \mathrm{CH}, 30 \mathrm{CH}, 200 \mathrm{CH}, 1000,5.000,10.000$, 50.000 , etc.

Até o momento da visita ao serviço, em junho de 1998, a potência máxima utilizada havia sido a LM18. De acordo com os cálculos da farmacêutica, um frasco de $60 \mathrm{ml}$ custava, na época inicial do atendimento, aproximadamente $R \$ 0,42$ e um de $120 \mathrm{ml}$, aproximadamente $R \$ 0,46$, valor que incluia o microglóbulo, frasco com cânula e solução hidroalcoólica. Na época da visita estimava-se este custo em $R \$ 0,90$, tendo ocorrido alteração de alguns fatores como uso de 1 microglóbulo para preparo de $120 \mathrm{ml}$, aviamento em frascos de $30 \mathrm{ml}$, e uso de gotejadores internos, em substituição às cânulas.

Em 1995 foram atendidos 561 pacientes no serviço. Em estudo de MARAVIESKI, foram aleatoriamente escolhidos 45 casos e obtidos os seguintes dados:

- idade de 0 a 51 anos.

- patologias variadas: digestivas, respiratórias, otites, genitourinárias, da pele (impetigo), circulatório, endocrinológicas e outros (enxaquecas, insônia, terror noturno, distúrbio do crescimento e do comportamento).

- 13 (29\%) pacientes apresentaram resolução de seus quadros clínicos no 10. retorno; 8 no 20 . retorno (18\%), 9 a partir do 30. retorno $(20 \%)$ e 15 não mais retornaram $(33 \%){ }^{(88)}$. 
Suas conclusōes eram de que a implantação da medicina homeopática no Serviço Público de Saúde tem mostrado ser uma boa solução porque:

- resgata e humaniza a relação médico-paciente;

- possibilita a implantação de atividades de Promoção de Saúde;

- melhora a qualidade e diminui o custo da assistência médica pela Rede Pública de Saúde devido ao baixo custo dos medicamentos homeopáticos, redução dos atendimentos ambulatoriais (nebulizações, etc.), diminuição dos custos com cuidados de enfermagem e de internações hospitalares ${ }^{(88)}$.

Não houve coleta de dados de prescrições ou fichas clínicas neste serviço. $\mathrm{Na}$ época da visita, a farmacêutica estava ausente. Posteriormente, ela enviou uma relaçăo de estoque dos medicamentos na escala cinqüenta milesimal, com as potências disponíveis, sempre prescritos na forma líquida. 


\subsection{1 - Relação de estoque de medicamentos:}

\begin{tabular}{|c|}
\hline Acidum nitricum LM 1 a 4 \\
\hline Aconitum napellus LM 1 a 3 \\
\hline Alumina $L M 1$ a 3 \\
\hline Anacardium orientale LM 1 e 2 \\
\hline Antimonium crudum LM 1 e 2 \\
\hline Antimonium tartaricum LM 1 e 2 \\
\hline Apis mellifica LM 1 e 2 \\
\hline Argentum nitricum LM 1 a 5 \\
\hline Amica montana LM 1 a 5 \\
\hline Arsenicum album LM 1 a 12 \\
\hline Aurum metallicum LM 1 a 3 \\
\hline Baryta carbonica LM 1 a 5 \\
\hline Belladonna LM 1 a 13 \\
\hline Borax veneta LM 1 a 3 \\
\hline Bryonia alba LM 1 a 5 \\
\hline Calcarea carbonica LM 1 a 18 \\
\hline Calcarea fluorica LM1 \\
\hline Calcarea phosphorica LM 1 a 7 \\
\hline Calcarea sulphurica LM 1 a 3 \\
\hline Carbo animalis LM 1 a 3 \\
\hline Carbo vegetabilis LM 1 a 3 \\
\hline Carcinosinum LM 2 a 6 \\
\hline Causticum LM 1 a 7 \\
\hline Chamomilla LM 1 a 8 \\
\hline Chelidonium majus LM 1 \\
\hline China officinalis LM 1 a 3 \\
\hline Cina maritima LM 1 a 3 \\
\hline Colocynthis LM1 \\
\hline Drosera LM 1 e 2 \\
\hline Dukamara LM 1 e 2 \\
\hline Ferrum metallicum LM 1 a 3 \\
\hline Ferrum phosphoricum LM 1 a 3 \\
\hline Gelsemium sempervirens LM 1 e 2 \\
\hline Graphites LM 1 a 3 \\
\hline Hepar sulphuris LM 1 e 2 \\
\hline
\end{tabular}

\begin{tabular}{|c|}
\hline Hyoscyamus niger LM 1 a 7 \\
\hline Ignatia amara LM 1 a 5 \\
\hline lodum LM 1 e 2 \\
\hline Ipecacuanha LM 1 \\
\hline Kalium bichromicum LM 1 a 3 \\
\hline Kalium carbonicum LM 1 a 3 \\
\hline Kalium phosphoricum LM 1 a 3 \\
\hline Lachesis muta LM 1 a 6 \\
\hline Luesinum (Syphylllinum) LM 2 a 4 \\
\hline Lycopodium clavatum LM 1 a 9 \\
\hline Magnesia carbonica LM 1 a 5 \\
\hline Magnesia muriatica LM 1 a 3 \\
\hline Magnesia phosphorica LM 1 a 3 \\
\hline Medorminum LM 1 e 2 \\
\hline Mercurius solubilis LM 1 a 6 \\
\hline Natrium carbonicum LM 1 a 7 \\
\hline Natrum muriaticum LM 1 a 13 \\
\hline Natrium sulphuricum LM 2 e 3 \\
\hline Nux vomica LM 1 a 15 \\
\hline Papaver somniferum LM 2 a 4 \\
\hline Phosphorus LM 1 a 8 \\
\hline Platinum metallicum LM 2 e 3 \\
\hline Psorinum LM 2 a 4 \\
\hline Pulsatilla nigricans LM 1 a 15 \\
\hline Rhus toxicodendron LM 1 a 4 \\
\hline Sabadilla LM 1 a 3 \\
\hline Sepia succus LM 1 a 8 \\
\hline Silicea terra $\mathrm{LM} 1$ a 8 \\
\hline Staphysagria LM 1 a 14 \\
\hline Stramonium LM 1 a 11 \\
\hline Sulphur LM 1 a 8 \\
\hline Tarentula hispanica LM 3 \\
\hline Thuya occidentalis LM 1 a 4 \\
\hline Tuberculinum (Kock) LM 2 a 4 \\
\hline Veratrum album LM 2 a 6 \\
\hline
\end{tabular}




\section{5 - O ambulatório Médico Homeopático da Instituiçăo Alan Kardec-Alice Pereira (IAKAP), em Guarulhos:}

A Instituição Alan Kardec-Alice Pereira, de caráter filantrópico, localiza-se na periferia de Guarulhos, Jardim Presidente Dutra, na cabeceira norte da pista do aeroporto de Cumbica. O local foi visitado e seus coordenadores entrevistados.

Foi fundada em 1958 com o objetivo de ser um hospital psiquiátrico, porém logo verificou-se que a necessidade da população carente local era de programas assistenciais, e assim surgiu uma creche para atendimento às crianças. Esta creche foi depois ampliada para uma escola de 1a. a 4a. séries, das 7 às 17 horas. Uma vez que o programa visa atender às famílias, todas as crianças que estudam até a $4 a$. série deviam estar nesta escola.

A renda mensal per capita das familias atendidas era, no máximo, de $R \$$ 65,00 . Mesmo que a família tivesse uma renda superior a este valor, outros indicadores, como pais alcoólatras ou toxicômanos, também podiam ser considerados para aceitação da criança. A maior parte das crianças provinha de uma favela vizinha à escola.

As 300 crianças atendidas possuiam de 2 a 14 anos. No período da manhã recebiam aulas normais, cumprindo o currículo oficial e durante a tarde preparavam lições e brincavam. Durante as férias, brincavam ou faziam passeios. Eram servidas refeiçōes e as crianças tomavam banho antes de retornarem às suas casa.

A assistente social da Instituição entrevistava cada família duas vezes ao ano, além de visitá-la anualmente. 
A Instituição criou ainda o "Projeto Tutela" ou Apadrinhamento, com voluntários contribuindo mensalmente para a educação de uma determinada criança.

Havia uma médica pediatra presente nas tardes de 3as. e 5as. feiras, que atendia rotineiramente às crianças tanto em relação à Puericultura Escolar (acompanhando o crescimento $\mathrm{e}$ as ocorrência mais comuns, como verminoses, anemias e desnutriçăo, assim como os aspectos sociais, pedagógicos e psicológicos das crianças), quanto às intercorrências agudas. Em 1999 a assistência médica deveria passar a ser diária. Crianças com patologias crônicas eram encaminhadas para 0 atendimento no ambulatório de Homeopatia.

Em 1987, a diretoria da Instituição aceitou uma proposta para a instalação de um atendimento exclusivamente homeopático em seu ambulatório, considerando a existência de outros serviços convencionais próximos e a possibilidade de se oferecer uma nova opção terapêutica a seus assistidos.

O novo ambulatório Homeopático passou a ser conduzido por um grupo de médicos homeopatas de São Paulo. Sem um método clínico comum, cada médico mantinha a sua linha própria de conduta, dependendo de suas preferências doutrinárias dentro da Homeopatia, o que dificultou o entrosamento clínico, e o grupo não tardou a se desfazer.

Reuniram-se então outros médicos, com o objetivo de prestar uma assistência homeopática padronizada que possibilitasse a intercomunicaçăo sobre os pacientes e a avaliação comum dos resultados.

Ficou decidido que a última palavra de HAHNEMANN sobre cada assunto seria o ponto de partida para a experimentação clínica. Surgiu a necessidade de um texto que sintetizasse os princípios clínicos 
hahnemannianos e que pudesse representar um compromisso técnico de trabalho entre os diversos clínicos que atendiam no ambulatório. Este texto começou a ser elaborado em janeiro de 1989 e foi concluído com a publicação do "Manual Clínico do ambulatório Médico Hahnemanniano da IAKAP", fundamentado na $\mathrm{VI}$ edição do Organon. O objetivo deste Manual era facilitar a consulta dos textos de HAHNEMANN e concentrar a compreensão que seus autores alcançaram da obra deste autor. Sobre a VI edição do Organon foram acrescentados principios encontrados na sua Matéria Médica Pura, Doenças Crônicas e Escritos Menores, desde que estivesse de acordo com a última edição do Organon ${ }^{(68,70,71,74)}$.

$\mathrm{Na}$ época da visita ao serviço, o ambulatório de Homeopatia ocorria aos sábados, com a presença de 1 ou 2 médicos, das 9:00 às 17:00 horas. Eram atendidos cerca de 20 pacientes, em consultas médicas homeopáticas que duravam 20 minutos, ou mais, se necessário. Neste horário eram atendidas também algumas crianças, mas especialmente suas famílias, além de ser aberto à comunidade local. A algumas familias com mais recursos; era solicitado que contribuissem com $5 \mathrm{~kg}$ de arroz/paciente/mês.

Conforme as instruçōes da $6^{*}$ ediçăo do Organon, os pacientes eram tratados com um medicamento por vez, sempre dinamizados na escala cinqüenta-milesimal. $\mathrm{O}$ tratamento começava pelas primeira potências (LM1 ou LM2), que eram gradualmente elevadas a cada 7 ou 15 dias.

Inicialmente o ambulatório de homeopatia funcionava com um estoque de 5 frascos de cada potência (de LM1 a LM30) de cada um dos 48 medicamentos antipsóricos ${ }^{21}$, além de poucos outros para quadros agudos. Os medicamentos eram gratuitamente fornecidos pela farmácia

\footnotetext{
${ }^{21}$ Antipsóricos são medicamentos indicados por HAHNEMANN para o tratamento de doenças crônicas.
} 
homeopática HN-Cristiano, de São Paulo, através de convênio informal, e armazenados em uma sala própria na Instituição.

Logo se percebeu, entretanto, que esse grande número de frascos de diferentes potências gerava muito desperdício, pois as não utilizadas eram desprezadas a cada 2 anos. Sendo assim, passou-se a estocar 4 unidades das primeiras 5 potências de cada medicamento, sendo as potências seguintes solicitadas à farmácia após o retorno do paciente, caso a evolução tivesse sido satisfatória. Após um período de tempo, para eliminarse a necessidade do Dispensário de medicamentos e adequar-se às normas da Vigilância Sanitária, todos os medicamentos passaram a ser pedidos sob encomenda. Uma semana após o primeiro atendimento, cada paciente passou a receber as potências que usaria no periodo até a próxima consulta, em embalagem individualmente identificada pela farmácia. Os retornos eram marcados dentro do período de uso das potências, para que o paciente não ficasse sem medicamento entre a consulta e a chegada de novas potências da farmácia. Para otimizar custos, os frascos usados eram lavados e devolvidos à farmácia para reutilização.

\subsection{1 - Análise dos medicamentos prescritos:}

Segundo uma relação de 3.613 frascos de medicamentos prescritos durante o ano de 1996, fornecida pelo responsável pelo atendimento médico da Instituiçăo, pudemos estudar a demanda naquele serviço.

No estoque eram mantidos 42 medicamentos, dos quais 14 não foram prescritos nenhuma vez durante 0 ano. Foram eles: Agaricus, Anacardium orientalis, Antimonium crudum, Clematis, Digitalis, Graphites, Magnesia carbonica, Manganum, Mezereum, Phosphoric acidum, Platinum, Rhus toxicodendron, Sarsaparrilla e Stannum metalicum. 
$\mathrm{Na}$ TABELA 31 pode-se verificar os 10 medicamentos mais prescritos, que totalizaram $90,8 \%$ do total de medicamentos indicados durante 0 ano.

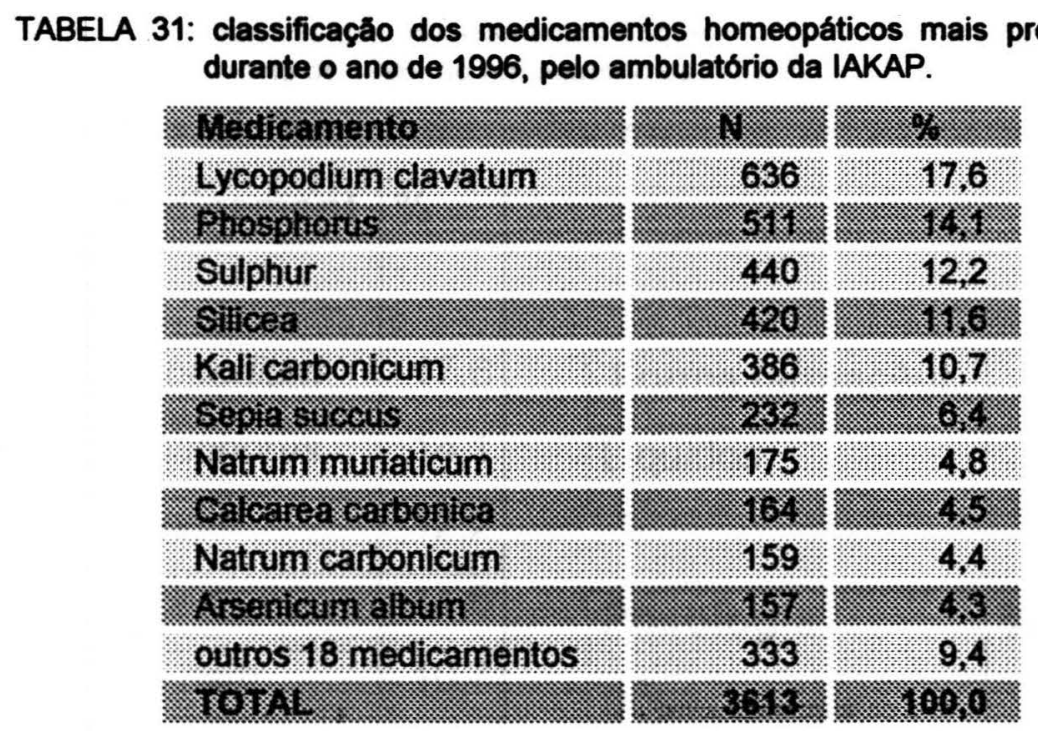

Os 18 medicamentos menos utilizados foram: Alumina, Ammonium carbonicum, Ammonium muriaticum, Arnica montana, Aurum metallicum, Baryta carbonica, Borax, Carbo animalis, Carbo vegetabilis, Causticum, Conium maculatum, Hepar sulphuris, lodium, Magnesia muriatica, Muriatic acidum, Nitric acidum, Sulphuric acidum e Zincum metallicum.

Em relação à forma farmacêutica, todos os medicamentos foram prescritos como líquidos, a serem administrados em doses repetidas.

Apesar de apenas 10 medicamentos significarem $90,8 \%$, estão pulverizados em suas diversas potências, devido à técnica de prescriçăo. Assim, Lycopodium clavatum foi prescrito

\subsubsection{1 - Resumo dos medicamentos mais prescritos:}


O QUADRO 9 mostra um resumo dos medicamentos homeopáticos mais prescritos na IAKAP.

QUADRO 9: resumo dos medicamentos homeopáticos mais prescritos durante o ano de 1996, no ambulatório da IAKAP.

\begin{tabular}{|l|r|}
\hline $\begin{array}{l}\text { Medicament } \\
\text { o }\end{array}$ & \\
\hline Lycopodium & 17,6 \\
\hline Phosphorus & 14,1 \\
\hline Sulphur & 12,2 \\
\hline Silicea & 11,6 \\
\hline Kali carb. & 10,7 \\
\hline Sepia succus & 6,4 \\
\hline Natrum mur. & 4,8 \\
\hline Calcarea & 4,5 \\
\hline Natrum carb. & 4,4 \\
\hline Arsenicum & 4,3 \\
\hline Diversos & 9,4 \\
\hline
\end{tabular}

\begin{tabular}{|l|c|}
\hline Forma farmacêut. & $\%$ \\
\hline Líquidos & 100,0 \\
\hline
\end{tabular}

\begin{tabular}{|l|l|}
\hline Posologia & $\%$ \\
\hline Dose repetida & 100,0 \\
\hline
\end{tabular}

\begin{tabular}{|c|c|}
\hline \multicolumn{1}{|c|}{ Escala } & $\%$ \\
\hline LM & 100,0 \\
\hline
\end{tabular}

\section{6 - Ambulatório Municipal de Homeopatia em Campinas}

Campinas está localizada no interior do estado de São Paulo, distando cerca de $100 \mathrm{~km}$ da capital. Possui aproximadamente 100 médicos homeopatas e uma população com cerca de 1 milhão de habitantes.

Contatada inicialmente para uma reunião (em 1997) com a finalidade de esclarecer os médicos em relação a questões sobre medicamentos, fui informada de que desejavam instalar uma farmácia própria no local. A partir 
de uma pesquisa realizada pelo mesmo grupo de médicos, com o uso de Thuya occidentalis, concluíram que a qualidade da tintura utilizada influenciava nos resultados clínicos. Este fato levou-os a desejar conhecer mais sobre a qualidade dos medicamentos homeopáticos ${ }^{(83)}$.

O ambulatório Municipal de Homeopatia de Campinas foi fundado em 1989 e hoje faz parte da Policlínica. Iniciou com apenas um médico, mas este número foi crescendo e hoje já são 7 homeopatas, um deles atendendo exclusivamente adolescentes.

A demanda era grande. Até aquela época já haviam sido realizadas 6.300 consultas, e esperava-se chegar a $10.000 \mathrm{em} 1998$.

Para o coordenador do serviço, era fundamental oferecer o medicamento gratuitamente, pois nos pequenos períodos que ficaram sem medicamento, a procura pelo atendimento homeopático caiu. Muitos pacientes tinham poucos recursos, até mesmo para pagar o transporte para chegar ao local de atendimento.

O ambulatório recebia encaminhamento de 40 postos de saúde do Município. Embora a centralização facilitasse alguns aspectos, para a população seria melhor se houvesse um maior número de ambulatórios descentralizados.

Durante a reunião informaram que desejavam saber o custo básico para esta montagem, com uma relação inicial de 50 tinturas-mãe e medicamentos dinamizados até a $200 \mathrm{CH}$, incluindo os equipamentos necessários, matérias primas ativas e inertes (água, álcool, glóbulos de sacarose, lactose e glicerina), estantes e contratação de um farmacêutico.

Até então o fornecimento dos medicamentos ocorria através de uma farmácia conveniada, que dista cerca de 8 quadras e foi homologada pela 
Prefeitura através de levantamento de preços. Os pacientes atendidos no serviço homeopático recebiam gratuitamente 0 medicamento. As prescrições eram elaboradas em 2 vias: uma ficava com o paciente e a outra era enviada pela farmácia para a Prefeitura, que após alguns meses pagava à farmácia.

O sistema tinha alguns inconvenientes, entre eles demora no atendimento, mas principalmente o relacionamento entre alguns médicos e a equipe da farmácia, que acabava por suscitar dúvidas com relaçăo à qualidade dos medicamentos. Tais problemas foram superados após algumas reuniões: a conduta passou a ser mais franca, as críticas diminuíram e a confiança aumentou.

A partir da idéia inicial de montar uma farmácia homeopática no local, decidiu-se, no início de 1999 , transferir todo o serviço para um prédio apropriado, localizado em uma região da cidade mais adequada, onde inclusive, no futuro, seria possivel estabelecer a farmácia própria.

Segundo informaçōes prestadas pela farmacêutica que atendia o serviço, as prescriçōes advindas do ambulatório Municipal de Homeopatia eram anotadas no Livro de Registro de Receituário, junto com todas as outras receitas atendidas. A maior parte dos medicamentos eram prescritos sob a forma líquida. Quando havia atendimento médico no serviço de origem, recebia cerca de 20 receitas ao dia, contendo principalmente medicamentos dinamizados, embora também, em cerca de 1 ou 2 prescrições ao dia, tinturas, pomadas e cremes. A maior parte dos medicamentos eram solicitados em potências até a $30 \mathrm{CH}$ e bem diversificados. Quanto à posologia, existiam tanto prescriçōes em dose única, como em doses repetidas, bem como aquelas com apenas um medicamento ou com 2 ou 3 por receita. Eram prescritos também outros tipos de medicamentos, como essências florais e minerais Oligossóis, pelos quais os pacientes deviam 
pagar.

\section{7 - Programa de Fitoterapia e Homeopatia da Prefeitura de Ribeirão Preto:}

Em entrevista, a coordenação do Programa de Fitoterapia e Homeopatia da Secretaria Municipal da Saúde realizado em conjunto com a Secretaria Municipal do Meio Ambiente, da Prefeitura Municipal de Ribeirão Preto, contou que o Programa foi iniciado em 1992 e instituído e homologado pela Prefeitura e Câmara Municipal em 1994, com o apoio da II Conferência Municipal de Saúde.

Os objetivos do programa eram oferecer, gratuitamente, opção de Prática Natural de Saúde à comunidade, buscando resgatar as espécies medicinais em extinção e orientar sua utilização correta, unindo o conhecimento popular à pesquisa científica, além de incentivar a utilização da Homeopatia no tratamento de saúde.

O Programa era desenvolvido em um ambulatório Central de Fitoterapia e Homeopatia. A coordenação considera que seriam necessários 10 médicos homeopatas para 0 atendimento da população. As primeiras consultas tinham a duração de 1 hora, e as consultas de retorno, 30 minutos. Estavam padronizando uma ficha clínica modelo para anotaçōes relativas ao atendimento. Os médicos homeopatas também podiam prescrever o uso de plantas medicinais, mas não de essências florais.

Os medicamentos eram comprados do Instituto François Lamasson e da Faculdade de Farmácia da USP (ambos localizados em Ribeirão Preto), a partir de uma lista padronizada. A dispensação era centralizada, e o paciente escolhia buscar o medicamento no endereço central ou retornar ao local da consulta após 2 ou 3 dias, para onde sua prescrição seguiria, via 
malote. Deve-se ressaltar que o nível de informações sobre Homeopatia na cidade era grande, pois o Instituto François Lamasson, além de divulgar esta terapêutica para a população, formava clínicos e farmacêuticos desde - início da década de 80 , tendo sido responsável pela abertura de um grande número de farmácias homeopáticas na cidade.

O farmacêutico responsável pelo fornecimento dos medicamentos em geral, inclusive os homeopáticos, juntamente com os médicos homeopatas, conseguiram instituir uma lista padronizada com cerca de 30 medicamentos, em frascos com $15 \mathrm{~g}$ de glóbulos, nas potências $6 \mathrm{CH}, 30 \mathrm{CH}$ e $200 \mathrm{CH}$.

Segundo o farmacêutico, a compra através de licitação considerava năo só - custo, como também a qualidade do medicamento, difícil de ser avaliada. Para o farmacêutico, a qualidade estava vinculada à eficácia e à segurança; como não tinha como avaliar o medicamento, já que não podia doseá-lo, preferia ter o respaldo daqueles preparados na Faculdade de Farmácia da USP (Ribeirão Preto).

Os medicamentos das 3 primeiras licitações foram efetivamente produzidos por esta Faculdade, quando apenas 2 médicos atendiam. Pela pouca experiência na época, houve muita sobra de alguns medicamentos, e o Centro de Saúde devolveu para a Faculdade cerca de 200 frascos.

O farmacêutico gostaria de oferecer o medicamento em todas as unidades que contam com o atendimento médico homeopático, porém devido à variedade $e$ grande quantidade de medicamentos, o custo seria muito elevado. Uma possibilidade seria reduzir a lista de medicamentos para cerca de apenas 20 itens, ainda que tivesse dúvidas de que os clínicos aprovassem esta medida. Existia a falta de medicamentos, porque a demanda era alta e as licitaçōes geravam processos demorados. Eram enviadas relações com os medicamentos faltantes, para que os médicos 
evitassem prescrevê-los. Caso não houvesse o medicamento prescrito ao paciente e ele não pudesse comprá-lo, tentava contatar o médico para uma possivel substituição. Considerava que 0 ideal seria que tivessem um laboratório de manipulação homeopática na Secretaria Municipal de Saúde, que era a idéia inicial.

O nível socio-econômico dos pacientes atendidos pelo serviço era relativamente alto, e até podiam comprar os medicamentos, quando necessário.

\section{8 - O Centro Homeopático de Saúde Pública de Dourados:}

Dourados é uma cidade de cerca de 155.000 habitantes, localizada a 224 km de Campo Grande, no Estado de Mato Grosso do Sul. O ambulatório de Homeopatia em Saúde Pública de Dourados iniciou suas atividades em 1984 e foi oficializado pela Secretaria de Saúde do Município em maio de 1992, transformando-se então no Centro Homeopático de Saúde Pública.

Na época da entrevista com o coordenador do serviço, em 1997, o Centro atendia a cerca de 800 consultas por mes, contando com 2 clínicos gerais, 2 pediatras e 1 psicóloga, profissional esta que integrava a equipe desde 1985, tendo sido especialmente treinada para elaborar um relatório com a história clínica do paciente, facilitando chegar ao medicamento constitucional $^{22}$, e abreviando assim o tempo da consulta. Os clínicos recebiam o relatório, procediam à anamnese homeopática e prescreviam o medicamento constitucional individualizado, em potências até C1000, em dose única ou repetida.

\footnotetext{
${ }^{22}$ Medicamento constitucional para um indivíduo é aquele de importância fundamental durante sua vinda inteira. É determinado pelo homeopata por comparaçăo das características e sintomas do paciente com aqueles encontrados em Repertórios.
} 
Existia o registro de mais de 11.000 pacientes atendidos apenas com medicamentos homeopáticos. O coordenador do serviço afirmou "não serem organicistas puros, mas sim fazerem uma homeopatia clínica-científica. Utilizavam o medicamento constitucional, ao lado do medicamento do miasma ${ }^{23}$ e o do órgão doente, se necessário".

Pacientes com nivel sócio-econômico mais elevado também eram atendidos pelo serviço, que funcionava das $8: 00$ às 17:00 horas, diariamente. $O$ coordenador do projeto foi convidado para ser médico "residente" em Homeopatia, isto é, estar presente diariamente, em periodo integral, garantindo $o$ atendimento homeopático da população. Em caso de urgência noturna ou durante o final de semana, a população era orientada a procurar o serviço de Pronto Socorro.

O medicamento era fornecido pelo próprio serviço, logo em seguida à consulta, adquirido de farmácias homeopáticas da cidade, após processo de licitação pública, segundo uma lista básica com 120 substâncias, nas potências $6 \mathrm{CH}, 12 \mathrm{CH}$ e $30 \mathrm{CH}$, em glóbulos, na forma de doses únicas ou repetidas. Quando o médico prescrevia um medicamento que não constasse da lista, ou que tivesse acabado, o paciente teria que comprá-lo. Caso ele não pudesse pagá-lo, as farmácias costumavam fornecê-lo gratuitamente para o paciente.

Planejavam, na época da entrevista, fazer um novo inventário nos medicamentos, e uma nova concorrência pública, com a participaçăo das 4 farmácias homeopáticas da cidade. O coordenador achava positivo que houvesse alternância do fornecimento dos medicamentos entre as farmácias. Para ele, as farmácias estavam atentas e preocupadas com a qualidade do medicamento, provavelmente pelo fato dele ser um homeopata

\footnotetext{
${ }^{23}$ Miasma é definido por HAHENMANN como o princípio infeccioso, ou vírus, que, pode estabelecer doenças especificas em dado organismo. Outros textos do século XIX definem miasmas como um eflúvio ou emanaçăo peculiar advinda de terrenos pantanosos ${ }^{(133)}$.
} 
experiente, há 30 anos na cidade, tendo feito o curso de Homeopatia em 1984 na APH e contar com o apoio da Prefeitura.

Durante os anos de 1992 a 1996 este apoio faltou, e o Centro ficou sem o fornecimento de medicamentos, período no qual os pacientes preferiram comprar o medicamento, do que năo ter o atendimento homeopático. As farmácias, especialmente a Cristal, doavam o medicamento caso o paciente não pudesse pagar por ele, como continuam fazendo até hoje, quando necessário.

A primeira farmácia a manipular medicamentos homeopáticos na cidade, fornecia os medicamentos para o Centro Homeopático, utilizando uma senha para identificar as prescriçōes dos pacientes carentes, que recebiam a medicaçăo gratuitamente. Como passou a existir mais 4 farmácias na cidade, que, embora registradas como Farmácias de Manipulação, também preparavam e forneciam medicamentos homeopáticos para o Centro de Saúde, foi criado o sistema de compra por licitação.

\section{9 - Os ambulatórios da Associação Paulista de Homeopatia -} APH:

A Associação Paulista de Homeopatia (APH) é uma sociedade civil, fundada em 1936, reconhecida como de Utilidade Pública Municipal e Estadual, com sede à rua Dr. Diogo de Faria $n^{\circ} 839$, na cidade de São Paulo. Sem fins lucrativos, é uma instituição representativa dos médicos homeopatas do Estado de São Paulo, que tem finalidades educativas e científicas (pesquisa, divulgação e ensino da Homeopatia, entre outras) e humanitárias (atendimento ambulatorial) ${ }^{(13)}$.

Realiza cursos de Homeopatia para médicos, farmacêuticos, cirurgiōes dentistas e veterinários, desde o início da década de 80 . Os cursos para 
clínicos constituíam-se de aulas teóricas e práticas, estas últimas realizadas sob a forma de atendimento ambulatorial na própria sede da APH. O ambulatório de Ensino tem como objetivo principal o aprendizado. Existem ainda os ambulatórios de Sócios, destinados ao treinamento e reciclagem de médicos já formados em Homeopatia. $\mathrm{O}$ objetivo dos ambulatórios é também atendimento da populaçăo. Ambos são assistidos por 1 ou 2 orientadores, contando ainda com 1 ou mais monitores. No total, funcionavam na APH 21 ambulatórios, sendo 18 voltados para o ensino e 3 exclusivamente para sócios. Sua duraçăo era de 4 horas, exceto os 4 que recebiam os alunos do interior, que tinham 10 horas de duraçăo. Existe também um ambulatório de Veterinária, que ocorria no consultório do coordenador. A TABELA 32 mostra os diversos tipos de ambulatórios e o número de horas de atendimento semanal.

\footnotetext{
TABELA 32: relaçăo dos tipos de ambulatórios e o número de horas de atendimento por semana, na APH.
}

\begin{tabular}{|c|c|}
\hline 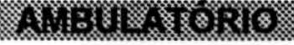 & 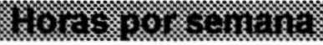 \\
\hline Ensino & (1) $: 20$ \\
\hline SToxitas & 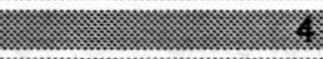 \\
\hline Pesquisa & 1 \\
\hline
\end{tabular}

Em 1997 foram atendidos 256 casos novos, sem incluir os retornos (menos que um caso novo atendido ao dia). No final daquele ano, à época do estudo das fichas clínicas, existiam um total de 23.697 pacientes relacionados.

Um ambulatório normalmente comporta até um máximo de 14 pessoas, incluindo os orientadores, monitores e os alunos. $O$ limite é o espaço físico. 0 ambulatório de alunos do interior usa uma sala dupla, para cerca de 25 alunos.

Durante o curso, existe um ambulatório que é feito no salăo principal de aulas, com a classe toda, uma vez ao mes. Os alunos do primeiro ano 
tinham um contato inicial com a Propedêutica e Semiologia Homeopática e para aqueles do terceiro ano elas eram apresentadas com as tendências filosóficas pessoais de diversos professores.

Os 5 ambulatórios de Sócios eram de presença livre para médicos sócios, sendo que só os monitores tinham presença obrigatória. Já os ambulatórios de Ensino eram de frequeencia obrigatória para os alunos e para os monitores.

O periodo de atendimento do ambulatório de Ensino sempre acabava sendo excedido. Nas 4 horas, era atendida uma consulta nova e 2 retornos, ou então apenas 3 retornos. Sempre existiam intercorrências que faziam com que os alunos tivessem oportunidade de ver a abordagem de casos agudos.

Alguns Orientadores estabelecem normas próprias em seus ambulatórios, tais como: atendimento de pacientes até 8 anos, exclusivamente Pediatria ou quanto à conduta terapêutica ${ }^{24}$.

Em relação à população atendida nos outros ambulatórios, não havia restrição em relação à faixa etária. Atendia a uma população de 0 a 70 anos, concentrando-se principalmente em crianças. A freqüencia era maior de mulheres do que homens, como observado em outros serviços públicos do Municipio de São Paulo( ${ }^{(9)}$.

Anteriormente havia atendimento principalmente de trabalhadores da construção civil e empregadas domésticas. Na época da visita, eram pacientes também indivíduos da classe média, porém desempregados e em dificuldades financeiras. Como a APH é uma entidade de utilidade pública, devia atender a todos, mesmo que o paciente fosse de classe social mais

\footnotetext{
${ }^{24}$ Seguia estritamente as instruçőes da $6^{\circ}$ edição do Organon: os pacientes eram tratados com um medicamento por vez, preparados segundo o método cinquenta-milesimal. 0 tratamento começava pelas primeiras potencias disponíveis, que eram gradualmente elevadas a cada 7 ou 15 dias.
} 
elevada. Existia o projeto de ter uma assistente social para triar e ter critérios para privilegiar os carentes. No final do $2^{\circ}$ semestre de 1998 existia uma lista de espera de cerca de 600 pessoas para conseguir ingressar no atendimento.

Em relação às patologias mais freqüentes, encontravam-se problemas respiratórios (principalmente bronquite e asma), infecçōes recidivantes (urinárias, amigdalites, otites, etc.), enxaquecas, alguns casos com hipertensão, etc.

Ocorria abandono do tratamento, estimado em até $50 \%$, provavelmente devido à demora para o atendimento. Embora fosse recomendaçăo da APH, especialmente considerando que não existia no local um prontoatendimento, alguns médicos não forneciam meios de serem encontrados por seus pacientes em caso de necessidade. Faltas às consultas eram incomuns e os pacientes eventualmente esperavam até 3 a 4 horas pelo atendimento.

Os orientadores recebiam uma pequena remuneração por seu trabalho, cuja finalidade principal era o aprimoramento profissional e prestígio pessoal, para ascensão política na própria instituição.

Os pacientes eram encaminhados por outras instituições e ainda por alunos, ex-alunos, farmácias homeopáticas, programas de rádio, TV, etc.

Nos ambulatórios não era permitida a utilização de outros recursos terapêuticos, como medicamentos alopáticos ou terapias alternativas, ainda que para pacientes diabéticos, com hipertensão arterial, convulsões, etc., era mantida a medicação tradicional específica. Tentava-se retirar aos poucos os corticóides de pacientes asmáticos. Tanto para a prescrição de medicamentos alopáticos, como para a realização de exames complementares, os pacientes eram encaminhados para o serviço médico 
público (Centro de Saúde) da região em que residiam, pois poucos tinham planos de saúde particulares.

A APH contava com um pequeno estoque de medicamentos homeopáticos para urgências, fornecido gratuitamente pelos farmacêuticos que trabalhavam no ensino da Associação. Após a consulta, a secretária indicava um elenco de farmácias homeopáticas onde os medicamentos prescritos nas consultas dos ambulatórios podiam ser adquiridos. Em caso de tratar-se de paciente carente, a prescrição recebia um carimbo de "Atendimento Social" e o medicamento era fornecido gratuitamente ao paciente por uma das farmácias do mesmo grupo, que não era reembolsada pela APH. Antes desta iniciativa, alguns pacientes abandonavam 0 tratamento por não terem recursos para a compra dos medicamentos prescritos.

Em entrevista, a coordenadora dos ambulatórios, afirmou que as farmácias homeopáticas ligadas ao ensino da APH tinham um maior compromisso com a qualidade dos medicamentos.

Citou que, em visita a um laboratório industrial homeopático, percebeu que aspectos comerciais, como a venda de sabonetes, etc., não prejudicava a qualidade dos medicamentos homeopáticos, além de ajudar a manter o negócio. A produçăo de medicamentos homeopáticos clássicos unitários, feita em andar separado, era diferente daquela mecanizada dos complexos, que visavam o lucro como objetivo principal. Salas escuras e com ar condicionado destinavam-se ao armazenamento correto de matérias primas. Em outro andar, eram produzidos chás e pomadas.

Sua opção medicamentosa era pelos policrestos ${ }^{25}$, raramente prescrevendo potências superiores a $\mathrm{C} 1000$, pois preferia não usar altas potências feitas

\footnotetext{
${ }^{25}$ Policrestos săo medicamentos cuja experimentaçăo e aplicaçőes clínicas mostram que possuem um amplo uso, cobrindo uma grande variedade de sintomatologia mental, emocional e física. HAHNEMANN, na introduçăo de Nux vomica em sua Matéria Médica
} 
de forma mecânica no aparelho de Fluxo Contínuo. Sempre utilizou potências rastreadas, como $18,24,33,60,100,200,210 \mathrm{CH}$, etc., não tendo apenas um método para prescrição.

Quanto à forma farmacêutica acreditava que os pacientes gostavam mais de ingerir glóbulos. Sua desvantagem era ser muito apreciado por crianças, que os ingeriam desnecessariamente, além de serem alterados por açăo da umidade.

Não percebia diferença na ação de medicamentos vindos de diferentes fornecedores, provavelmente porque fornecia uma orientação prévia sobre o local de compra. Era raro acontecer de ter muita certeza do medicamento e este não funcionar. Quando este fato ocorria, pensava primeiro em ter indicado o medicamento errado e só depois na possibilidade da farmácia ter feito um medicamento incorreto. Através de informaçōes da sua clínica particular percebia que, quando o paciente já tinha um medicamento comprado anteriormente, dependendo de seu aspecto, indicava que o usasse se fosse caso de urgência, e só depois adquirisse um novo frasco. Notava que, quando guardado de forma correta, protegido de fontes de radiações, de luz e calor forte, geralmente a ação do medicamento era boa, mesmo que esse já tivesse 5 anos ou mais.

Os médicos do ambulatório da APH costumavam orientar os pacientes a comprar os medicamentos em uma das farmácias da lista. Tanto os médicos quanto os pacientes aceitavam a situaçăo de não ter o medicamento disponivel na APH. Na pós-consulta, a secretária perguntava ao paciente se o médico havia indicado alguma farmácia e, em caso positivo, fornecia seu

Pura, define policrestos como: "Existem poucos remédios nos quais a maioria dos sintomas correspondem em similaridade a algumas doenças comuns, e que podem portanto ser efetivamente aplicados homeopatiacamente. Podemos chamar estes remédios de policrestos." ${ }^{(68,133)}$ 
endereço ao paciente. Caso contrário, indicava a mais próxima da residência ou do trabalho do paciente, a partir de uma relação.

A coordenadora considerava inviável montar uma farmácia na APH para dispensação, mas que seria bom ter um estoque de medicamentos para urgência, embora soubesse que ele seria incompleto, pois era próprio da Homeopatia a não-padronização.

Em relaçăo ao estabelecimento de um convênio com uma farmácia homeopática, considerava que só seria positivo se fosse com uma rede com diversos pontos de venda, o que nem existia na cidade de São Paulo.

A coordenadora do ambulatório da APH nunca participou de serviço médico homeopático que contasse com fornecimento gratuito de medicamentos. Trabalhou na Cruzada Homeopática, instituição de atendimento médico homeopático gratuito localizada no centro da cidade de São Paulo, onde os médicos atendiam uma vez por mês e recebiam uma pequena remuneração. Não se recorda se havia fornecimento gratuito de medicamentos. Trabalhou também em consultório localizado ao lado de um laboratório homeopático industrial, em São Paulo, cujo objetivo era concentrar diversos médicos homeopatas, incrementando o número de prescriçőes. Năo havia interferência por parte do laboratório, embora esperassem que os pacientes comprassem seus medicamentos na farmácia ao lado.

Dado o conhecimento que a autora tem da Associaçăo há diversos anos, e considerando que esta não possui um proprietário ou um administrador permanente, pode-se imaginar que haveria dificuldades para 0 gerenciamento de uma farmácia homeopática local pela ausência de um responsável permanente. Mantendo o esquema atual, a Associação dificilmente poderia arcar com os custos da farmácia, exceto se houvesse auxílio financeiro externo. Por outro lado, haveria a possibilidade de utilizála como Farmácia-Escola para o curso de Homeopatia para Farmacéuticos, 
e de fornecer os medicamentos necessários aos pacientes atendidos nos ambulatórios, que geraria maior possibilidade de serem padronizados, por serem provenientes de uma só farmácia. Atrelar a consulta gratuita ao medicamento fornecido gratuitamente pela APH a todos os pacientes, embora altamente desejável, não parece viável a menos que grandes transformações ocorram, tal como uma tentativa de padronização

\subsection{1 - Estudo das fichas clínicas:}

Foram estudadas as fichas clínicas de uma amostra de 79 pacientes (34\%), de todos os 232 pacientes atendidos durante o período de 3 de agosto a 12 de novembro de 1998. Durante este intervalo de tempo, para estes 232 pacientes foram feitos 915 atendimentos, seja em $1^{*}$ consulta, seja como consulta de retorno, o que significa uma média de 3,9 consultas por paciente.

Novamente, a partir de um caderno de anotações de todos os pacientes atendidos no período, foram selecionados $1 \mathrm{em}$ cada 3 . Em seguida, suas fichas clínicas foram separadas e seus dados anotados: nome, data de nascimento, profissão, datas das consultas e medicamentos prescritos. Alguns destes pacientes vinham sendo atendidos há diversos anos. No total, para estes 79 pacientes, foram anotadas 1497 indicaçōes de procedimentos realizadas ao longo do tempo, isto é, uma média de 18 indicações por paciente.

As dificuldades encontradas na análise das fichas clínicas foram devidas à existência de uma grande quantidade de informações nas fichas de alguns pacientes mais antigos no ambulatório, feitas por diferentes médicos, que usaram também diferentes técnicas. Às vezes, após uma longa história clínica manuscrita, de diversas páginas, era impossivel encontrar se houve prescrição ou não de medicamento, ou qual foi ela, pois as letras de alguns clínicos eram extremamente difíceis de ser lidas.

Do total das 1497 indicações, a maioria $(90,8 \%)$ foi de medicamentos homeopáticos dinamizados. Além deles foram encontradas, com baixa 
freqüência, anotações de "conduta expectante" (quando decidiu-se não medicar o paciente), outras na qual não foi possível identificar a conduta, uma pequena quantidade de prescrição de medicamentos alopáticos, Fitoterápicos (distribuídos como 1 errino, 1 compressa, 2 tinturas, 4 pomadas, 1 xarope) e outros (1 frasco de ácido clorídrico e 1 mineral catalítico), como pode ser verificado na TABELA 33 abaixo:

TABELA 33: classificação dos diferentes tipos de procedimentos provenientes
do estudo das fichas clínicas dos pacientes atendidos no
ambulatório da APH.

Entre as 1360 indicaçōes de medicamentos dinamizados, os 10 mais prescritos foram Lycopodium clavatum, Arsenicum album, Natrum muriaticum, Sulphur, Phosphorus, Lachesis, Pulsatilla nigricans, Calcarea carbonica, Silicea, e Nitric acidum. Considerando apenas os medicamentos dinamizados, estes 10 representam 62,5\% das indicações. Outros 116 medicamentos foram responsáveis pelo restante, 510 indicações (TABELA 34).

TABELA 34: classificaçăo dos medicamentos homeopáticos, quanto à escala, provenientes do estudo das fichas clínicas dos pacientes atendidos no ambulatório da APH.

\begin{tabular}{|c|c|c|}
\hline 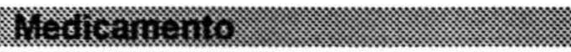 & (1: & \%. \\
\hline Lycopodium clavatum & $=187$ & 13,8 \\
\hline A & 10 & 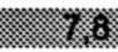 \\
\hline Natrum muriaticum & 104 & 7,6 \\
\hline 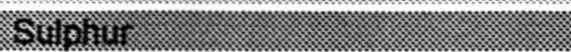 & 988 & 6.6 \\
\hline Phosphorus : : : & 86 & 6,3 \\
\hline F & 8 & 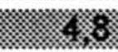 \\
\hline Lachesis & 64 & 47. \\
\hline 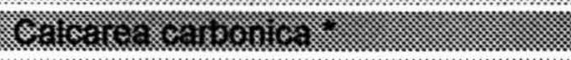 & x. & 32 \\
\hline Silicea & 48. & 3.5 \\
\hline 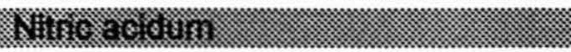 & 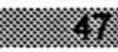 & 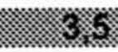 \\
\hline Outros medicamentos dinamizados & 510 & 37.5 \\
\hline 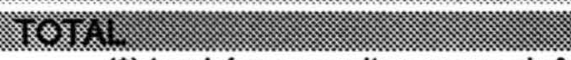 & 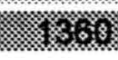 & 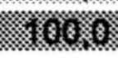 \\
\hline
\end{tabular}

(*) também prescritos como sinônimos 
Em relação à escala e ao método de dinamização, encontrou-se 224 prescrições sem indicação da escala, 109 prescrições de centesimais indicadas como $\mathrm{C}, 420$ de centesimais indicadas como $\mathrm{CH}$ e 33 de fluxo contínuo. Sabemos que nem todos os médicos prescrevem corretamente, diferenciando perfeitamente a escala e o método desejados em suas receitas através da nomenclatura $\mathrm{CH}$ e FC, o que é demonstrando até mesmo pela grande quantidade de prescriçōes utilizando a anterior notação C. Também devemos lembrar que a diferença entre $\mathrm{CH}$ e FC vem sendo implantada ao longo dos anos, sendo que temos prescrições do início da década de 90. Uma grande quantidade de anotações das fichas clínicas não continham indicação alguma quanto à escala. Nesta tese, para efeito de cálculo, foi considerado que as indicaçōes seriam de centesimais. Por estes motivos, na TABELA 13 abaixo foram reunidas todas as prescriçōes anotadas como $\mathrm{C}, \mathrm{CH}, \mathrm{FC}$ e ainda aquelas que continham uma potência, mas não uma escala determinada, como sendo centesimais, em um total de 786 frascos $(57,8 \%)$.

Os medicamentos conhecidos como "cinqüenta milésimas", anotados como L, LM ou $Q$, aparecem com um total de 541 indicações $(39,8 \%)$. Foi encontrada ainda uma porcentagem desprezível de prescriçōes em potências decimais $(0,2 \%)$ e em método misto $\mathrm{FC} / \mathrm{CH}^{1}(0,1 \%)$, como pode ser verificado na TABELA $35^{(23)}$. 
TABELA 35: classificaçăo dos medicamentos homeopáticos, quanto à posologia, provenientes do estudo das fichas clínicas dos pacientes atendidos no ambulatório da APH.

\begin{tabular}{|c|c|c|}
\hline Meteris: & 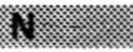 & 8. \\
\hline Centesimais & 786 & $\quad 57,8$ \\
\hline Beeninats: & 3.8 & $3 \times 2$ \\
\hline escala mista & 2 & 0,1 \\
\hline LU: & 5 & 60 \\
\hline náo especificado ( ) & 28 & 2.1 \\
\hline (8) & 8.63 & 18000 \\
\hline
\end{tabular}

A alta frequeência de indicações de medicamentos LM pode ser considerada surpreendente para esta instituiçăo já que as prescrições nesta escala provém quase que apenas de 1 ambulatório, que atende a um grande número de pacientes. Uma das explicações é devido ao fato de que a maioria dos clinicos que prescrevem centesimais nesta instituição o fazem como medicamento único. Cada consulta costuma gerar apenas a prescrição de apenas 1 frasco de medicamento centesimal. Por outro lado, no ambulatório que precreve apenas cinquenta-milesimais, cada consulta costuma gerar a prescriçăo de diversos frascos nesta potência.

Quanto à posologia, verificamos que foram indicadas mais doses repetidas do que doses únicas. Em $25 \%$ das indicações não foi declarada a posologia nas fichas clínicas, embora ela provavelmente estivesse declarada na receita (TABELA 36).

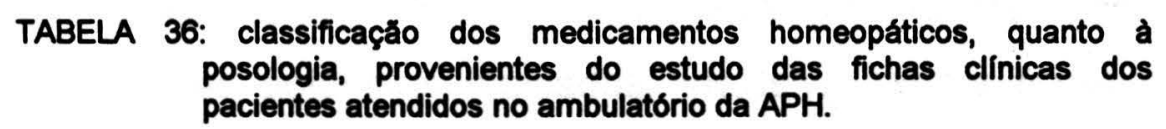
posologia, provenientes do estudo das fichas clínicas dos pacientes atendidos no ambulatório da APH.

\begin{tabular}{|c|c|c|}
\hline Fosiogigin & 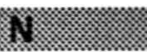 & x. \\
\hline Dose única & 265 & 19.5 \\
\hline 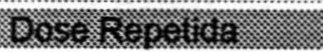 & 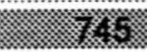 & (x) \\
\hline náo especificado ( & 350 & 25,7 \\
\hline$r$ & 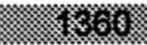 & 180.69 \\
\hline
\end{tabular}

(") foram consideradas as que năo tinham identificaçăo de escala ou potência.

\footnotetext{
${ }^{26}$ O método misto foi proposto pelo médico e professor argentino Alfonso Mazi ELIZALDI e constitui-se em uma dinamização através de Fluxo Contínuo, seguida por alguns passos realizados através do método hahnemanniano. Sua notaçăo é $\mathrm{FC} / \mathrm{CH}$ e tem sido pouco utilizado em nosso país.
} 
Em relação à distribuição das potências dos medicamentos dinamizados prescritos no ambulatório da APH, de um total de 1360 indicações foram utilizadas 137 potências diferentes, sendo que 7 destas representam $42,4 \%$ do total. Em 2,1\% das indicações, não foram encontradas anotaçōes nas fichas clínicas, como pode ser observado na TABELA 37.

TABELA 37: distribuiçăo dos medicamentos homeopático, quanto à potência, provenientes do estudo das fichas clínicas dos pacientes atendidos no ambulatório da APH.

\begin{tabular}{|c|c|c|}
\hline 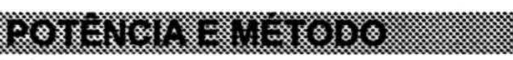 & 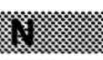 & 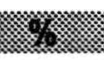 \\
\hline C6. & 92. & 6,8 \\
\hline (1) & \% & 8 \\
\hline 030 & 148 & 100 \\
\hline 0.006 & (x) & $=0.0$ \\
\hline 01000 & 58 & 4.6 \\
\hline 숭 & 6 & 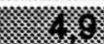 \\
\hline 050000 & 44 & 32 \\
\hline 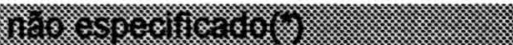 & 86. & 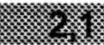 \\
\hline Ouras potenclas & 756. & 555 \\
\hline 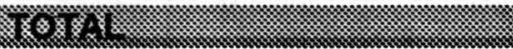 & 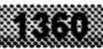 & 101003 \\
\hline
\end{tabular}

( $\left.{ }^{\star}\right)$ foram consideradas as que não tinham identificação de escala ou potência.

É interessante verificar que houve indicaçăo de potências muito variadas, desde muito baixas, como C2, até extremamente elevadas, como C200.000, C500.000, C1.000.000, até C5.000.000. Note-se que a atual Farmacopéia Homeopática Brasileira limita em FC 100.000 como potência máxima a ser utilizada pelo clínico. Outro ponto a ser observado é a extrema variabilidade que existe entre as potências indicadas, inclusive com a prescriçăo de algumas chamadas "intermediárias", como C25, C31, C240, C1012, C1024 e C1048, por exemplo ${ }^{(60)}$.

Verificamos uma grande variação entre os medicamentos indicados, possivelmente pelo fato de tratar-se de uma instituição de ensino, um local de estudo de diferentes medicamentos e de técnicas de uso de suas diferentes escalas, potências e métodos, e ainda pelo fato de que cada ambulatório era livre para utilizar o método homeopático da forma que 
desejar. Esta liberdade era ainda maior para os ambulatórios de Sócios, sendo que um deles indicava apenas medicamentos LM. Não existia a preocupação de adequar-se a um estoque de medicamentos prédeterminado, já que não havia a proposta de fornecimento de medicamentos.

\subsubsection{1 - Resumo dos medicamentos mais prescritos}

O QUADRO 10 mostra um resumo dos medicamentos homeopáticos mais prescritos na APH.

QUADRO 10: resumo dos medicamentos homeopáticos mais prescritos, em estudo de amostra das fichas clínicas provenientes de pacientes atendidos na APH.

\begin{tabular}{|l|r|}
\hline Medicamento & \multicolumn{1}{c|}{$\%$} \\
\hline Lycopodium & 13,8 \\
\hline Arsenicum & 7,8 \\
\hline Natrum mur. & 7,6 \\
\hline Sulphur & 6,6 \\
\hline Phosphorus & 6,3 \\
\hline Pulsatilla & 4,8 \\
\hline Lachesis & 4,7 \\
\hline Calcarea & 3,9 \\
\hline Silicea & 3,5 \\
\hline Nitric acidum & 3,5 \\
\hline Outros & 37,5 \\
\hline TOTAL & 100,0 \\
\hline
\end{tabular}

\begin{tabular}{|l|r|}
\hline \multicolumn{1}{|c|}{ Potências } & \multicolumn{1}{c|}{$\%$} \\
\hline CH6 & 6,8 \\
\hline CH30 & 10,5 \\
\hline C200 & 9,5 \\
\hline C1000 & 4.3 \\
\hline C1000 & 4.9 \\
\hline Outras & 64,0 \\
\hline TOTAL & 100,0 \\
\hline
\end{tabular}

\begin{tabular}{|l|r|}
\hline Posologia & \multicolumn{1}{l|}{$\%$} \\
\hline Dose repetida & 54.8 \\
\hline Dose única & 45,2 \\
\hline TOTAL & 100,0 \\
\hline
\end{tabular}

\begin{tabular}{|l|r|}
\hline \multicolumn{1}{|c|}{ Escala } & \multicolumn{1}{c|}{$\%$} \\
\hline Centesimal & 57.8 \\
\hline Outras & 42,2 \\
\hline TOTAL & 100,0 \\
\hline
\end{tabular}




\subsection{0 - Amostra de prescriçð̋es obtidas em 9 farmácias homeopáticas da cidade de São Paulo:}

Outra fonte de dados para esta pesquisa foi obtida a partir de prescrições médicas homeopáticas variadas, aviadas em farmácias homeopáticas da cidade de São Paulo, durante o segundo semestre de 1998. Trata-se de uma clientela aberta, de demanda livre, que dirige-se a determinada farmácia livremente. Visando conhecer o receituário de clínicos homeopatas da cidade de São Paulo, com a colaboração das farmacêuticas responsáveis pelos estabelecimentos, foram estudadas prescrições obtidas em 9 farmácias homeopáticas de diferentes bairros, sendo 6 delas da mesma empresa. As farmácias localizavam-se em diferentes bairros: Brooklin, Vila Mariana, Saúde, Santana, Pinheiros, Vila Nova Conceição, Moema, Santa Cecília e Higienópolis ${ }^{(41)}$.

Foram copiadas através de uma máquina de fax, todas as prescrições clínicas que chegaram às farmácias, perfazendo lotes de no mínimo 20 prescrições seqüenciais por estabelecimento. As prescrições foram classificadas em relação ao medicamento prescrito, forma farmacêutica, dose única ou repetida, potência e método de preparo dos medicamentos.

Foram relacionadas 211 prescriçōes, emitidas por 112 médicos. Estas 211 prescrições geraram 277 frascos de medicamentos. Uma vez que houve a prescrição de medicamentos compostos por diversas substâncias, as 211 prescriçőes contiveram 371 substâncias no total, sendo 138 diferentes substâncias.

As 10 substâncias mais prescritas foram Lycopodium clavatum, Calcarea carbonica, Ignatia amara, Lachesis, Mercurius solubilis, Sulphur, Arsenicum album, Nux vomica, Pulsatilla nigricans e Thuya occidentalis (TABELA 38). 
TABELA 38: classificaçăo dos medicamentos homeopáticos provenientes de amostra de prescriçőes de 9 farmácias homeopáticas da cidade de Săo Paulo.

\begin{tabular}{|c|c|c|}
\hline 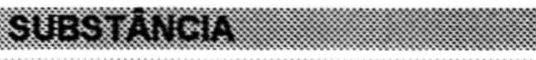 & 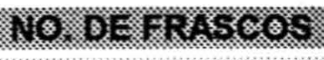 & 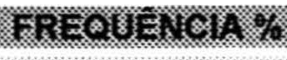 \\
\hline Lycopodium clavatum & 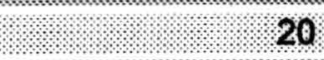 & $617: 5,3$ \\
\hline 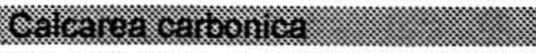 & 16 & 26 \\
\hline Ignatia amara & 14 & 3,8 \\
\hline 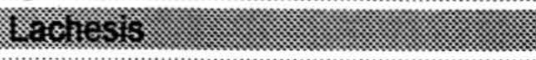 & 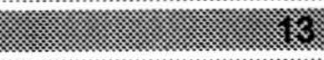 & 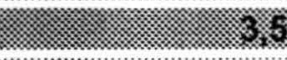 \\
\hline Mercurius solubilis & 12 & 3,2 \\
\hline S & $\frac{1}{10}$ & 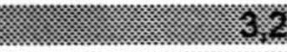 \\
\hline Arsenicum album & 10 & 2,7 \\
\hline 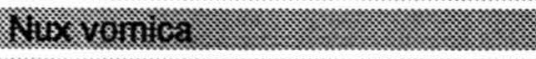 & 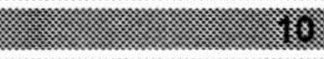 & 2 \\
\hline Pulsatilla nigricans & 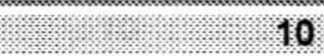 & 2,7 \\
\hline 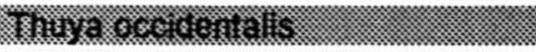 & 然 & 2 \\
\hline Diversas (outras 128 substancias) & 245 . & 66,2 \\
\hline TCBSA & $.8 \%$ & $280 \times 8$ \\
\hline
\end{tabular}

Podemos verificar que 10 diferentes medicamentos geraram 126 frascos de medicamentos, ou seja $34,0 \%$ deles. Para preparar os $66,0 \%$ restantes, foram necessárias 128 outras diferentes substâncias.

Em relação à forma farmacêutica foram prescritos principalmente líquidos e glóbulos, sendo $2,9 \%$ das prescriçőes relativas a outras formas farmacêuticas, conforme pode ser visto na TABELA 39.

TABELA 39: classificaçăo dos medicamentos homeopáticos, quanto à forma farmacêutica, provenientes de amostra de prescriçőes de 9 farmácias homeopáticas da cidade de Săo Paulo.

\begin{tabular}{|c|c|}
\hline 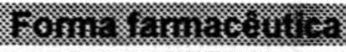 & \% \\
\hline fiquido & 50,9 \\
\hline 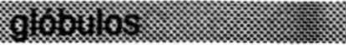 & 46.2 \\
\hline outras: & 2,9 \\
\hline rex & $\frac{1}{636} 8$ \\
\hline
\end{tabular}

Quanto às potências mais freqüentemente prescritas foram elas as $6 \mathrm{CH}$, $30 \mathrm{CH}$ e a C200, aqui incluindo as $200 \mathrm{FC}$ e $200 \mathrm{CH}$, responsáveis por $67 \%$ das prescriçōes. Somando a $12 \mathrm{CH}$ e a $1000^{\circ}$ potência, cobrimos $75,6 \%$ das potências dos medicamentos prescritos. Porém, no total, foram 32 potências centesimais, 7 decimais e 6 cinquenta-milesimais, isto é, 45 diferentes potências. Em relação à escala cinquenta-milesimal, foram prescritos 13 
frascos, isto é, $4,7 \%$ das prescrições (TABELA 40).

TABELA 40: classificaçắo dos medicamentos homeopáticos, quanto à potência,
provenientes de amostra de prescriçóes de 9 farmácias
homeopáticas da cidade de Săo Paulo.

Além de medicamentos homeopáticos, foram prescritos 12 frascos de 6 diferentes tinturas: Passiflora, Coentro, Própolis, Thuya, Gingko biloba e Bryophyllum, esta última usada especificamente na medicina antroposófica. Em relação às essências florais, foram prescritos 17 frascos, sendo 2 apenas com 1 essência floral e os outros 15 frascos com até 6 essências. É interessante notar que estas prescrições são anteriores à Resoluçăo 1499 do Conselho Federal de Medicina, publicada no início de setembro deste ano, que proibiu aos médicos a prescrição de terapias não cientificamente comprovadas. Além de tinturas e essências florais, foram prescritos outros medicamentos classificados como diversos, que inclui Sais de Schussler, vitaminas (vitamina $\mathrm{E}$, vitamina $\mathrm{C}$, complexo B, Aderogil $\circledast$, levedo de cerveja, minerais (Zinco plus $₫$, Oligosol $₫$, Gran White $₫$ ), fitoterápicos (Jarsin ou hipérico, kawa-kawa, Espinheira Composta, Citrin ou Garcinia e formulaçőes) e medicamentos antroposóficos complexos.

\subsection{1 - Resumo dos medicamentos mais prescritos:}

O QUADRO 11 mostra um resumo dos medicamentos homeopáticos mais prescritos nas amostra de farmácias homeopáticas da cidade de São Paulo. 
QUADRO 11: resumo dos medicamentos homeopáticos mais prescritos em estudo de amostra de prescriçס̃es de 9 farmácias homeopáticas da cidade de São Paulo.

\begin{tabular}{|l|c|}
\hline Medicamento & $\%$ \\
\hline Lycopodium & 5,4 \\
\hline Calcarea & 4,0 \\
\hline Ignatia & 3,8 \\
\hline Lachesis & 3,5 \\
\hline Mercurius & 3,2 \\
\hline Sulphur & 3,2 \\
\hline Arsenicum & 2,7 \\
\hline Nux vomica & 2,7 \\
\hline Pulsatilla & 2,7 \\
\hline Thuya occ. & 2,7 \\
\hline Outros & 66,1 \\
\hline TOTAL & 100,0 \\
\hline
\end{tabular}

\begin{tabular}{|l|l|}
\hline Forma farmacêut. & $\%$ \\
\hline Líquida & 50,9 \\
\hline Outras & 49,1 \\
\hline TOTAL & 100,0 \\
\hline
\end{tabular}

\begin{tabular}{|l|r|}
\hline Potências & $\%$ \\
\hline CH6 & 33,6 \\
\hline CH12 & 5,9 \\
\hline CH30 & 21,8 \\
\hline C200 & 11,6 \\
\hline C1000 & 2,7 \\
\hline Outras & 24,4 \\
\hline TOTAL & 100, \\
\hline
\end{tabular}

\begin{tabular}{|l|r|}
\hline Posologia & $\%$ \\
\hline Dose repetida & 54,8 \\
\hline Dose única & 45,2 \\
\hline TOTAL & 100,0 \\
\hline
\end{tabular}

\begin{tabular}{|l|c|}
\hline Escala & $\%$ \\
\hline Centesimal & 57,8 \\
\hline Outras & 42,2 \\
\hline TOTAL & 100,0 \\
\hline
\end{tabular}

Como se trata de estabelecimentos de clientela aberta, proveniente de qualquer médico homeopata da cidade, podemos notar que os 10 medicamentos mais prescritos representam apenas $33,9 \%$ das indicações. Pode-se entender este fato como decorrente da possivel liberdade na 
prescrição do clínico, já que os medicamentos não serão fornecidos segundo estoques pré-determinados. Também as potências prescritas atingem valores mais elevados. É interessante perceber que, quanto à escala, a prescrição é quase total de centesimais, e a posologia é quase toda de doses repetidas.

\subsection{1 - Comparação entre os diversos serviços, em relação ao tipo de fornecimento dos medicamentos:}

Ocorreram alterações na situação de fornecimento dos medicamentos, quando comparamos os dados encontrados na época do estudo, com a situação do final de 1998. Um resumo desta situação pode ser observada no QUADRO 12. 
QUADRO 12: comparação entre a situação de fornecimento dos diversos locais estudados, na época do estudo e no final de 1998.

\begin{tabular}{|c|c|c|}
\hline 1004 & 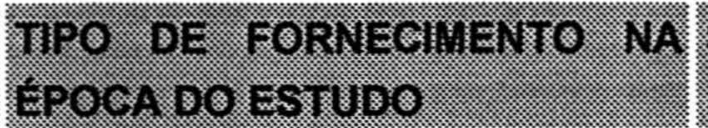 & 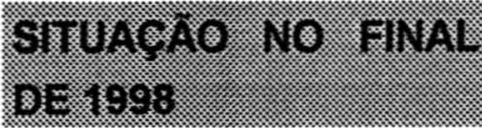 \\
\hline $\begin{array}{l}\text { CSE-GPS } \\
\text { USPI }\end{array}$ & $\begin{array}{l}\text { pacientes retiravam gratuitamente, } \\
\text { em farmácia conveniada, em outro } \\
\text { local }\end{array}$ & $\begin{array}{l}\text { desconto na farmácia } \\
\text { conveniada : }\end{array}$ \\
\hline 1tri, $8 P^{\circ}$ & 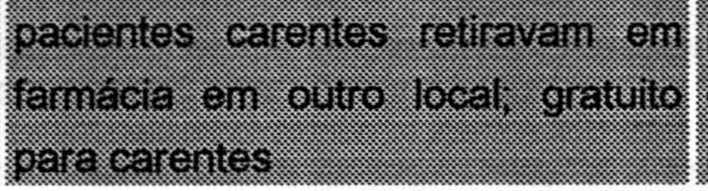 & 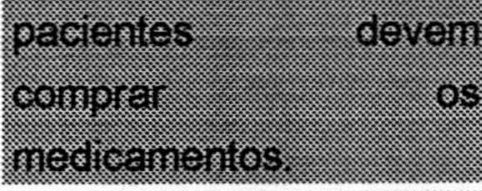 \\
\hline $\begin{array}{l}\text { Brumadinho, } \\
\text { MG }\end{array}$ & $\begin{array}{l}\text { farmácia no local, com } \\
\text { farmacéutico manipulando os } \\
\text { medicamentos. }\end{array}$ & o servico foi fechado. \\
\hline 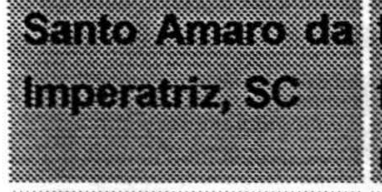 & 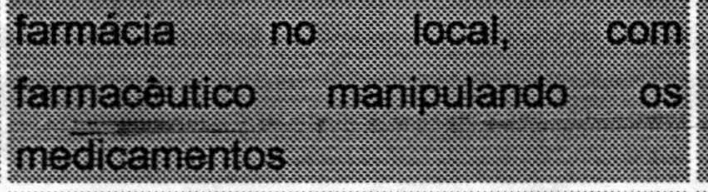 & 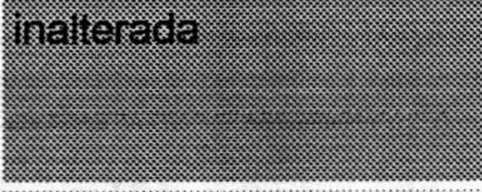 \\
\hline $\begin{array}{l}\text { AKAP, } \\
\text { Guarulhos, SP }\end{array}$ & $\begin{array}{l}\text { todos os pacientes recebem os } \\
\text { medicamentos, doados } \text { por } \\
\text { farmácia localizada em outro local } \\
\text { Mantimha estoques. }\end{array}$ & $\begin{array}{l}\text { paciente retoma para } \\
\text { receber o medicamento. }\end{array}$ \\
\hline 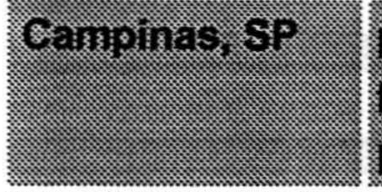 & 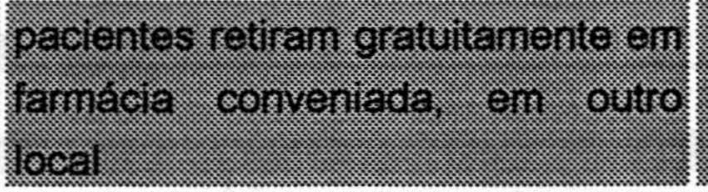 & \\
\hline 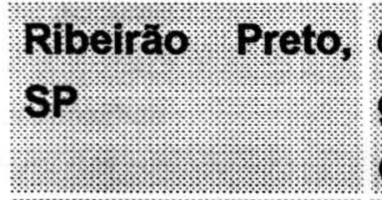 & $\begin{array}{l}\text { compra antecipada dispensaçäo } \\
\text { gratuita e centralizada no local } \\
\text { central de atendimento }\end{array}$ & \\
\hline Dortrados, 148 & 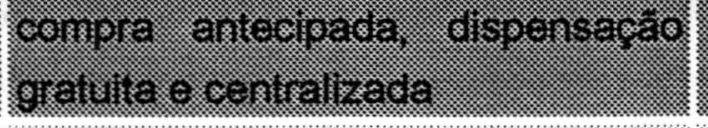 & \\
\hline APH, Săo Paulo & paciente compra onde quiser & $\begin{array}{l}\text { farmácias: } \\
\text { medicamentos: } \\
\text { carentes: }\end{array}$ \\
\hline 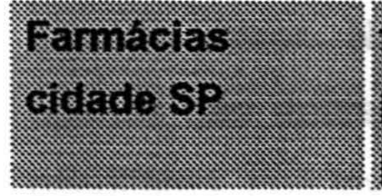 & 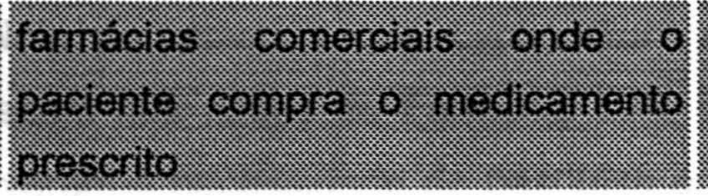 & \\
\hline
\end{tabular}


A TABELA 41 mostra uma comparação realizada entre os medicamentos mais prescritos dos diversos serviços estudados.

TABELA 41: comparaçăo entre os resumos dos medicamentos mais prescritos nos diversos serviços de atendimento médico homeopático estudados.

\begin{tabular}{|c|c|c|c|c|c|c|c|c|c|}
\hline & Fine & 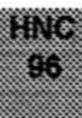 & $A$ & Exxinnad & (III) & 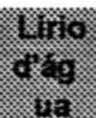 & S. & exinin & \% \\
\hline $\begin{array}{l}\text { Lycopodium } \\
\text { clavatum }\end{array}$ & 8.3. & 6.6 & 13.8 & 4.7 & 4,2 & & 5,4 & 43.0 & 12,1 \\
\hline 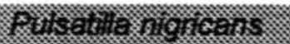 & 8.2 & 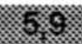 & 4,8 & 5.4 & 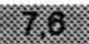 & 8.9 & $2, \pi$ & $4: x^{2}$ & 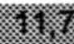 \\
\hline Arsenicum album & 47 & 5.9 & 7,6 & 4.5 & 6.6 & 6.9 & 27 & 38.9 & 10.9 \\
\hline SWIII: & 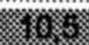 & 80 & 60 & 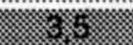 & $1 / 2$ & & 62 & 88.6 & 81 \\
\hline Phosphorus & 5.1 & 6.6 & $6,3$. & 2,4 & 2,7 & 4,1 & x. & 27.2 & 7,6 \\
\hline Lactiosis: & & $5 \times 9$ & 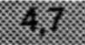 & & 1,5 & 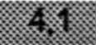 & कर & 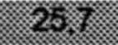 & 72 \\
\hline Calcarea carbonica & 4.9 & 5.9 & 8,9 & & 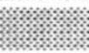 & 6.2 & 4 & 24.9 & 7,0 \\
\hline I: & 3.4 & 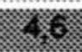 & & $3 \times 9$ & 56 & & $2 \%$ & 2,2 & $8 \times 8$ \\
\hline Natrum muniaticum & 6.9 & & & 3.5 & 8.9 & & & 19.3 & 5,4 \\
\hline 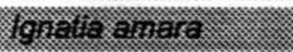 & & & & 49 & $\sqrt{2} \cdot$ & & $8 \times 8$. & 18.3 & 3.7 \\
\hline Anica montana & & & & 5.7. & & 3.5 & & 92 & 2,6 \\
\hline 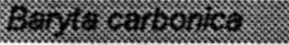 & & & & & & 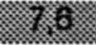 & & 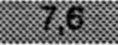 & 2. \\
\hline Belladonna & & & & & & 6.9 & & 69 & 1,9 \\
\hline 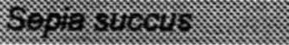 & & & & & & 689 & & 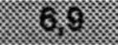 & 1.9 \\
\hline Causticum & & 3,3 & & & 3,2 & & & 6.5 & 1,8 \\
\hline ; & 29 & & 35 & & & & & 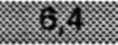 & 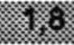 \\
\hline Thuya occidentalls & "x. & 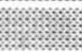 & (3: : & 2.7 & : & : & 2.7. & 5,4 & 1.5 \\
\hline Craminonilfa & 42 & & & & & & & 182 & 12 \\
\hline Nitric acidum & & & 3,5 & & & & & 3.5 & 1,0 \\
\hline 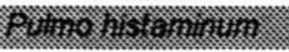 & & & & & & 8.5 & & 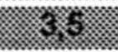 & $\frac{1}{8}$ \\
\hline Carcinosinum & & $3,3$. & & & & & - & 3,3 & 0,9 \\
\hline 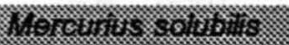 & & & & & & & 62. & 3,2 & $8 \times 9$ \\
\hline TOTAL & 61,2 & 51,9 & $54,7$. & 432 & m & 56.6 & 33.9 & 355.6 & : \\
\hline
\end{tabular}

A comparaçăo entre os 7 serviços estudados, a partir dos dados disponíveis, leva-nos aos 10 medicamentos mais prescritos para uma amostra maior. Nela percebemos que Lycopodium clavatum e Sulphur apenas não aparecem nos dados da Farmácia Lírio D'Água, cujos dados peculiares, nos levaram à necessidade de pesquisa em uma amostra mais aleatória. 
Alguns medicamentos seguramente podem ser indicados no estabelecimento de Listas Básicas de Medicamentos Homeopáticos, outros só devem ser confirmados com estudos que considerem variáveis regionais.

A TABELA 42 mostra a comparação das potências mais prescritas entre os medicamentos indicados nos diversos serviços estudados.

TABELA 42: comparaçăo entre os resumos das potências mais utilizadas nos diversos serviços de atendimento médico homeopático estudados.

\begin{tabular}{|c|c|c|c|c|c|c|c|}
\hline So & 1718,6 & 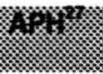 & Bis & 1 & 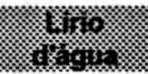 & $x x^{\prime}$ & $1 / \%$ \\
\hline 6 & 19.1 & 68 & $28 \%$ & 244 & $=1911$ & 83.6 & 22.0 \\
\hline 第 & 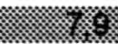 & $x$ & 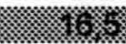 & 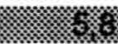 & (x) & 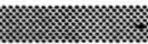 & 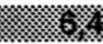 \\
\hline 12 & 10.5 & $x$ & 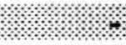 & 13.3 & 105 & 5.9 & 6.7 \\
\hline 8 & 18 & 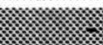 & 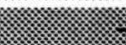 & 13 & 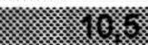 & $=$ & 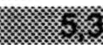 \\
\hline 30 & 290 & 105 & 199 & 180 & 290 & 2118 & 24,3 \\
\hline 18 & : & . & 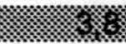 & x. & m. & x & 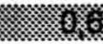 \\
\hline 200 & 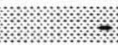 & 9.5 & 52 & x. & (2) & 116 & 4,4 \\
\hline$=1988$ & $x$ & $(x+3$. & 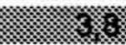 & $=$ & $x$ & 2. & 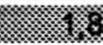 \\
\hline 10000 & x & 49 & (1) & ") & (1) & . & 07 \\
\hline 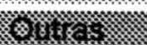 & 2 & 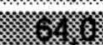 & 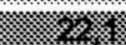 & $2 \%$ & 28 & 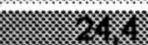 & 18 \\
\hline TOTAL: & 100,0 & 1000 & 100,0 & 1000 & 1000 & 100,0 & $100 \%$ \\
\hline
\end{tabular}

Observando os serviços estudados, destacamos uma concentraçăo de utilização das potências 6 e $30 \mathrm{CH}$, que somam $43,3 \%$ do total prescrito.

Da mesma forma como foi elaborada uma tabela para comparação entre as substâncias e potências mais prescritas, pode-se repetir o estudo para verificar a comparação entre as escalas, métodos e formas farmacêuticas mais prescritos.

${ }^{27}$ Para a APH constatou-se uma dispersão muito grande dos dados relativos às potências utilizadas, provavelmente face a diferentes correntes médicas homeopáticas que convivem o mesmó espaço ambulatorial, diferenciando-se dos outros serviços quanto à concentraçăo de determinadas potências. 


\section{5 - DISCUSSÃO:}

\section{1 - Medicamentos essenciais à população: história e problemática das ações já implementadas.}

A Organização Mundial de Saúde (OMS) elaborou, em 1977, a primeira Lista Modelo de Medicamentos Essenciais, com o objetivo de satisfazer as necessidades de atenção à saúde da maior parte da população. Estes medicamentos deveriam estar disponiveis em quantidades suficientes e nas formas farmacêuticas adequadas. No Brasil foi instituida a RENAME (Relação Nacional de Medicamentos Essenciais), através da Portaria Interministerial no. 6, de 18 de março de 1980. Esta Relação já estava prevista desde a instituiçăo da Central de Medicamentos (CEME), que tinha como objetivo estar inteiramente voltada à promoção e organização do fornecimento de remédios àqueles que, por suas condições econômicas, não pudessem adquiri-los aos preços vigentes. Deviam compor esta Relaçăo de drogas de maior eficácia e menor toxicidade, que tivessem produção, custo e distribuição compativeis com as condições do pais. ${ }^{(122)}$.

O Programa de Assistência Farmacêutica da CEME tinha como proposta principal atender à população carente de recursos, para que, após o atendimento médico, ela contasse com a possibilidade de receber gratuitamente o medicamento necessário à sua recuperação e volta à produtividade. Os objetivos desse Programa eram os seguintes ${ }^{(122)}$ :

1. disciplinar a aquisição de produtos farmacêuticos no sistema oficial da saúde;

2. orientar prioridades para a produção interna de matérias primas farmacêuticas;

3. desvincular o receituário de marcas e fabricantes, introduzindo a idéia dos medicamentos genéricos; 
4. atingir maior rentabilidade, com grandes aquisições centralizadas;

5. manter medicamentos eficazes, seguros e de ampla cobertura, para prevenção e tratamento de patologias mais freqüentes;

6. facilitar a atuação da Vigilância Sanitária;

7. diminuir custos dos medicamentos, sem propaganda ou embalagens sofisticadas;

8. adequar oferta de medicamentos às patologias;

9. facultar o controle de preços ${ }^{(122)}$.

\section{2 - Critérios para definição das Listas de Medicamentos}

\section{Essenciais:}

Propostas de estudo sobre o uso de medicamentos, como o Programa de Ação sobre Drogas Essenciais da OMS, cujo objetivo é melhorar a disponibilidade e tornar racional o uso destas drogas para a populaçăo, não têm suas recomendações facilmente aplicáveis. Segundo este Programa, a disponibilidade de medicamentos está longe de ser atingida e o uso inadequado das drogas, ainda é regra. Considera-se que mais pesquisas são necessárias para fornecer ferramentas que melhorem o método de prescrição, dispensação e utilização dos medicamentos ${ }^{\text {(131,132). }}$

Para estabelecer uma seleção dos medicamentos essenciais, deve-se ter em conta os seguintes critérios:

1. a relação de benefício/risco;

2. possibilidade de simples entendimento do modo de administração do medicamento, e conseqüente obediência do paciente à prescrição;

3. facilidade de produção, distribuição, conservação, dispensação, armazenamento, transporte;

4. custo compativel do tratamento;

5. principio ativo ser de produção interna; 
6. incidência das patologias;

7. hábitos regionais.

Em 1999, uma nova RENAME foi disponibilizada através da página eletrônica ("home-page") do Ministério da Saúde ${ }^{28}$. Examinando-a, percebemos que os medicamentos homeopáticos não preenchem os critérios de informações suficientes sobre a biodisponibilidade e características farmacocinéticas, facilidade para cálculo da dose a ser administrada, além de podermos questionar a comprovação seu valor terapêutico ${ }^{(96)}$.

Apesar de estabelecer que uma lista de medicamentos essenciais não deve ser estanque, pois requer atualizações permanentes à luz da evolução do conhecimento científico e do perfil de morbidade e mortalidade do país, LUCCHESI afirma que não houve alterações com relação à RENAME anterior. Do novo texto apreende-se que este será a base para a organização de listas estaduais e municipais, sendo meio fundamental para orientar a padronização, quer da prescrição, quer da dispensação e do abastecimento de medicamentos, particularmente no ammbito do SUS. Constitui-se hoje não um procedimento burocrático, mas um anseio que norteia a política de assistência farmacêutica, para que esta efetivamente promova acesso da população brasileira aos medicamentos necessários e às açōes de prevenção, promoção e recuperação da saúde da população. Deve estar inserida no planejamento das instituições e ser difundida para os prescritores. Na prática, a RENAME anterior teve uma implantação difícil, tendo sido mais utilizada nos serviços ambulatoriais das redes das Secretarias Estaduais de Saúde ${ }^{(38,96,122)}$.

Como cada comunidade deveria elaborar sua própria Relação Básica, adequada às patologias da população, observando sazonalidades,

\footnotetext{
${ }^{28} \mathrm{http}: / /$ www.saude.gov.br/rename/htm
} 
ADAMES apresenta uma relação local, de Campo Grande, em Mato Grosso do Sul, na qual os medicamentos foram divididos em 3 categorias: ambulatoriais, de urgência e insumos. Relata que, mesmo tendo implantado uma Lista informatizada, ocorriam faltas e excesso de medicamentos nos Centros de Saúde da rede, mas demonstrou que, com uma adequação é possivel haver uma otimização na utilização dos recursos, tendo sido possivel $\mathrm{o}$ atendimento total dos medicamentos necessários à população ${ }^{(3)}$.

\section{CAVALCANTI ressaltou que}

"(....)a RENAME aponta para a racionalização do consumo de medicamentos, excluindo produtos ineficazes, supérfluos e que impliquem em riscos aos usuários. .... significa um mecanismo importante para a nova conceituação do comportamento prescritor do médico, que ao consultá-la, encontrará uma relaçăo criteriosa de medicamentos, que o afastará da incômoda posição de cliente dos laboratórios farmacéuticos e da prática do uso irracional de medicamentos, libertando o receituário da dependência dos produtos de marca e da propaganda da indústria" (38).

Afirmou ainda que $86 \%$ dos insumos utilizados na fabricação de produtos farmacêuticos são importados, criando dependência e maiores custos para o país ${ }^{(38)}$.

BERMUDEZ lastima que a maioria dos países da América Latina não esteja contemplando 0 acesso da população aos medicamentos essenciais, parte integrante e prioritária das reformas que vêm sendo implementadas no setor saúde. O Brasil constitui-se como um dos 5 maiores mercados farmacêuticos do mundo, sendo que a maioria dos produtos farmacêuticos mais vendidos tem esta condiçăo às custas de campanhas milionárias de pressão sobre a prescrição, a dispensação ou a compra pela população ${ }^{(30)}$. 
A dificuldade para manter fundos necessários para a assistência à saúde é encontrada no mundo inteiro, especialmente em cenários de mudanças econômicas. Esta dificuldade é ainda maior nos países em desenvolvimento, porém mesmo aqueles com mais recursos vêm seus gastos em saúde aumentando freqüentemente. É fácil perceber a importância que a Farmacoeconomia ${ }^{29}$ apresenta neste panorama. Os custos relativos aos medicamentos podem ser divididos em:

- diretos, relativos aos produtos e serviços;

- indiretos, que consideram também os efeitos clínicos, os aspectos econômicos e humanitários ${ }^{(110)}$.

REIS cita o estudo de Johnson e Bootman sobre a morbidade e mortalidade relacionadas a medicamentos que indicam como um problema sanitário de extrema relevância, com gastos estimados em U\$ 76,6 bilhões anuais nos Estados Unidos, além de 200.000 mortes e 9 milhões de internações. A pesquisa dos resultados econômicos e humanitários da terapia medicamentosa é um campo relativamente novo. A seleção apropriada de medicamentos, a prevenção de complicações resultantes de terapias medicamentosas agressivas e a redução do uso inadequado de produtos farmacêuticos podem diminuir os custos totais de forma mais importante do que a simples redução de compra de medicamentos ${ }^{(110)}$

Quatro métodos de avaliação econômica podem ser utilizados para o estudo dos medicamentos :

1. análise de redução de custos, aplicada quando 2 ou mais alternativas oferecem o mesmo resultado terapêutico, podendo-se escolher a alternativa mais barata para reduzir os gastos.

29 Farmacoeconomia é o estudo da descriçăo e análise dos custos da terapia medicamentosa para os sistemas de saúde e para a sociedade. 
2. análise de custo-efetividade, utilizada quando os resultados são medidos em unidades não monetárias, como redução de pressão sangüinea, de dias de internação, etc.

3. análise de custo-benefício, quando a comparação é feita tanto em função do custo financeiro, quanto dos resultados.

4. análise de custo-utilidade, quando os resultados são medidos através de indicadores como indices de qualidade de vida, por exemplo ${ }^{(110)}$

SOARES, estudando aspectos antropológicos farmacêuticos, considera que "(....) os medicamentos não existem em si mesmos, mas adquirem significados e funçžes diversas de acordo com o contexto político, económico, social e cultural em que são utilizados e devem ser analisados por causa de sua dinámica nos processos sociais."

\begin{abstract}
A Antropologia Farmacêutica estuda também a percepção que a população tem acerca dos medicamentos $e$ as alteraçōes nesta percepção; os significados para os pacientes, profissionais de saúde e populaçăo em geral dos medicamentos e suas relaçōes com conceitos de saúde/doença e de cura; a percepção sobre eficácia e riscos, etc. É um campo a ser estudado, que poderia trazer informaçōes interessantes sobre como o medicamento e a terapêutica homeopática são vistos pela população ${ }^{(121)}$.
\end{abstract}

\title{
5.3 - O medicamento homeopático:
}

Os mesmos critérios apresentados anteriormente aplicam-se ao medicamento homeopático. De início, é necessário considerar que tanto a assistência médica homeopática quanto os medicamentos homeopáticos, já constam de programas oficiais nos serviços públicos de saúde, e que portanto a população deveria ter acesso ao medicamento necessário à prática dessa terapêutica. Esta é uma recomendação também da Proposta de Implantação de uma Unidade-piloto na Rede Pública do SUS e do V 
Forum Nacional de Homeopatia na Rede Pública, ambos da Comissão de

Saúde Pública da AMHB: o medicamento deve estar disponível, seja em farmácia local, conveniada ou na forma de estoque no serviço ${ }^{(11,42)}$.

Partindo dos critérios considerados para inclusão de uma nova droga na RENAME, podemos comparar com a situaçăo específica para a Homeopatia (QUADRO 13).

QUADRO 13: enquadramento da Homeopatia em relaçăo aos requisitos para inclusăo de uma nova droga na RENAME.

\begin{tabular}{|c|c|}
\hline REOUISTO & HOMEOPATIA \\
\hline 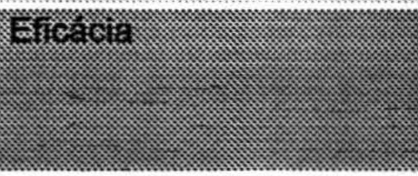 & 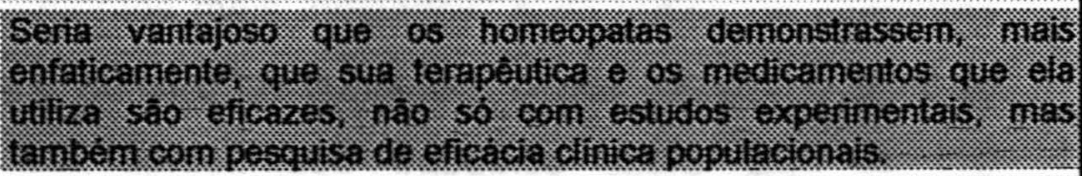 \\
\hline $\begin{array}{l}\text { Especificacós de } \\
\text { Qualidade e métodos de } \\
\text { Controle definidos e: } \\
\text { ieprodutiveis : }\end{array}$ & $\begin{array}{l}\text { Os métodos de Controle de Qualidade para os medicamentos } \\
\text { homeopáticos náo sáo satisfatorios, pois nâo levam a identificacăol } \\
\text { nem ao doseamento. }\end{array}$ \\
\hline Seg: & 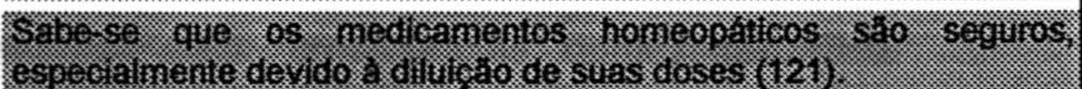 \\
\hline Custo do tra & $\begin{array}{l}\text { Medicamentos acessivets enbora possam existir técnicas de } \\
\text { prescricáo mais dispendiosas (ro): }\end{array}$ \\
\hline 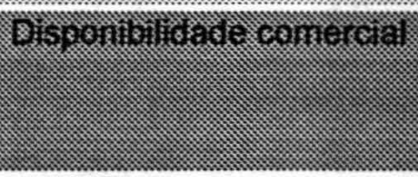 & 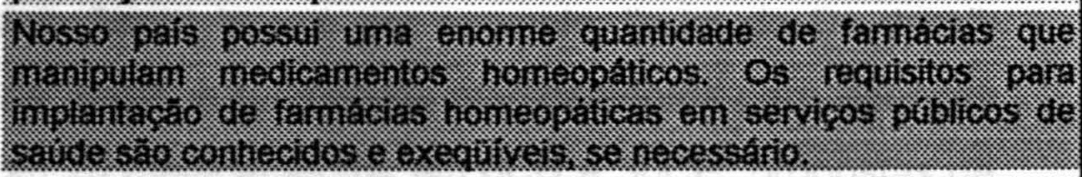 \\
\hline $\begin{array}{l}\text { Dados de utilizaça em } \\
\text { outros paises }\end{array}$ & $\begin{array}{l}\text { Na Europa. México e ladia, é grande a porcentagem de médicos } \\
\text { que prescrevem. assim, como da populacáo que . Utiliza } \\
\text { medicamentos homeopáticos. }\end{array}$ \\
\hline 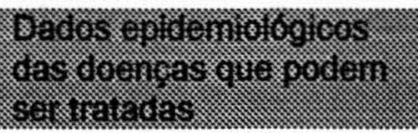 & 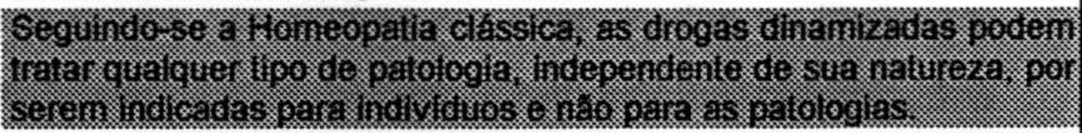 \\
\hline $\begin{array}{l}\text { Facilidade de } \\
\text { administracáo e } \\
\text { manuselo }\end{array}$ & $\begin{array}{l}\text { Os medicamentos horneopálicos säo administrados por via oral OS } \\
\text { globulos lém sabor agradável. }\end{array}$ \\
\hline 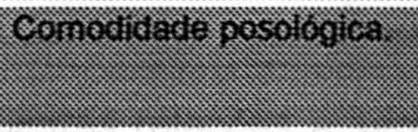 & 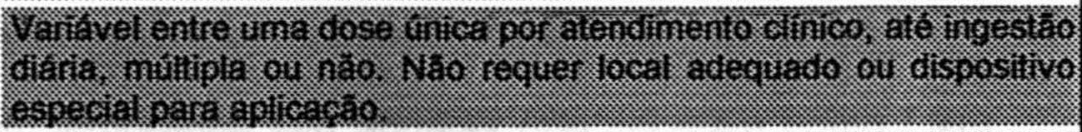 \\
\hline $\begin{array}{l}\text { Condicoes de : } \\
\text { amazenamento } \\
\text { estabilidade }\end{array}$ & $\begin{array}{l}\text { Requer protecäo contra excesso. de luz, calor e campos } \\
\text { eletromagnéticos, cuidados especificos que devem ser informados } \\
\text { aos responsaveis por sua producáo, transporte, amazenamento o } \\
\text { usuários. }\end{array}$ \\
\hline
\end{tabular}


O ponto que parece dificultar o estabelecimento de Relações Básicas de Medicamentos Homeopáticos, é a grande variação observada nas prescriçōes, relacionada com a individualização que é própria da Homeopatia. Quando consideramos os medicamentos homeopáticos, devemos lembrar que a aplicabilidade da divisão dos medicamentos entre aqueles ambulatoriais e os de urgência, depende do tipo de atendimento clínico, da formação homeopática do médico, seguindo ele a escola Unicista (mais direcionada ao indivíduo) ou aquela mais voltada à patologia.

O Programa de Ação sobre Drogas Essenciais da OMS, apresenta o conceito "dos 10 medicamentos mais indicados" e do índice de diferentes drogas prescritas sobre o número de consultas, o que fornece o grau de polifarmácia. KAYNE tem apresentado trabalhos sobre com os "10 medicamentos homeopáticos mais utilizados" ${ }^{n}$.

Conjuntos de medicamentos para emergências domésticas ("kits" ou "farmacinhas") sugeridos por diversos autores podem fornecer uma idéia inicial dos mais utilizados. Assim temos, por exemplo, "o kit do Dr. Jack", com 22 medicamentos na $30 \mathrm{CH}$; a relação de medicamentos para doenças agudas de Glasglow, com 20 medicamentos em $6 \mathrm{CH}$ e $30 \mathrm{CH}$; propostas de ULLMANN com 37 medicamentos em 6 e 30CH, sendo 4 deles para uso externo, além de diversos outros que podem ser encontrados na literatura. Farmácias e laboratórios homeopáticos comercializam estojos com relações pré-definidas de medicamentos básicos, ou que seguem listas solicitadas por clínicos homeopatas ${ }^{(\pi, 12 \pi}$.

Outras relaçōes a serem lembradas são aquelas que constam como Lista Básica de Medicamentos Homeopáticos em Anexos das edições da Farmacopéia Homeopática Brasileira, além daquelas de legislações específicas para a Homeopatia e a relação dos medicamentos policrestos. 
MOREIRA NETO, estudando amostra de 45 pacientes, todos com problemas respiratórios, encontrou a indicação de 20 medicamentos homeopáticos diferentes, sendo que 7 deles totalizaram $49 \%$ das prescrições. Nota-se que apesar das dificuldades, existe a possibilidade de elaborar Listas de Medicamentos Homeopáticos, para determinadas faixas etárias ou para patologias específicas, ainda que as listas dependam do método utilizado pelo clínico para prescrever ${ }^{(99)}$.

Considerando todos os dados obtidos na pesquisa desta tese, podemos afirmar que devem constar numa Lista de Medicamentos Homeopáticos Básicos: Lycopodium clavatum, Pulsatilla nigricans, Arsenicum album, Sulphur, Phosphorus, Lachesis, Calcarea carbonica, Nux vomica, Natrum muriaticum e Ignatia amara, responsáveis provavelmente por mais da metade das prescrições. A estes, pode-se somar certamente Arnica montana, Belladonna, Sepia succus, Causticum, Silicea, Thuya occidentalis e talvez ainda Baryta carbonica, Chamomilla, Nitric acidum, Pulmo histaminum e Carcinosinum. De qualquer forma é importante lembrar que este é um resultado estatístico. A Homeopatia busca individualizar o tratamento. Portanto, listas básicas devem ser consideradas pontos de partida; devem ser adequadas e revistas quanto à faixa etária, às patologias da população, e à sazonalidade.

Em relação ao pagamento do medicamento no ato de seu recebimento, os responsáveis por alguns dos serviços estudados afirmaram que a população aceita o fato de não receber os medicamentos gratuitamente, tendo que adquiri-los, e que continuaria freqüentando os serviços, ainda que passasse a pagar pelos remédios, como ocorre no CSE-GPS, em Itú, em Dourados, em Ribeirão Preto e na APH. Esta opinião talvez reflita a resignação de receber ao menos parte do atendimento gratuitamente, ou ainda a aceitação do que freqüentemente ocorre nos serviços públicos, em relação ao medicamento alopático, que deveria ser fornecido após a consulta, o que 
nem sempre ocorre.

Outro ponto é que o modelo de atendimento homeopático em nosso pais é fundamentado na figura do médico homeopata. Portanto, antes de mais nada é necessário termos o clínico; o medicamento aparece como conseqüência. Mesmo assim, as farmácias homeopáticas envolvidas com os serviços públicos têm fornecido medicamentos a preços mais baixos e até gratuitamente, de forma que os pacientes carentes tenham acesso aos medicamentos homeopáticos que Ihes foram prescritos. Ao lado da contribuição social das farmácias, existe um aspecto que passa por uma "solução pessoal" de problemas de comunidades, evidenciando a fragilidade existente para a plena implantação do atendimento homeopático. Por outro lado, outros responsáveis por serviços homeopáticos referenciaram desde a impossibilidade do atendimento médico sem fornecimento dos medicamentos, até uma queda na freqüência ao atendimento, em épocas em que este abastecimento faltou.

O custo médio dos medicamentos durante o tratamento homeopático no CSGPS, local do estudo-piloto, foi de $\mathrm{R} \$ 2,89$ por consulta. Apesar de não dispormos de dados comparativos para medicamentos alopáticos, podemos considerá-lo acessivel ${ }^{(99)}$.

Este custo mais baixo do tratamento homeopático é especialmente importante se considerarmos dados do IBGE, no estudo de famílias das regiōes Sudeste e Nordeste do país, sobre os gastos para a compra de medicamentos constituírem quase $90 \%$ das despesas mensais destinadas à saúde. Na região Nordeste, o gasto sobe a $93 \%$, sendo o restante dividido entre consultas médicas, internações hospitalares e exames variados ${ }^{(2)}$.

Mesmo entre os pacientes que têm acesso aos serviços públicos de saúde, muitos têm que pagar pelos medicamentos, além de existir uma alta 
incidência de automedicação em nosso país. Já que os gastos com saúde crescem com a idade, e sabendo-se que existe um aumento da vida média do brasileiro, a conseqüência será um maior número de pessoas, despendendo durante um maior número de anos, um valor cada vez maior, para adquirir medicamentos. Se este valor for diminuido, pela substituição por medicamentos mais baratos, haverá uma importante economia para a população, especialmente a de baixa renda. Esta é uma contribuição importante que pode advir da utilização de medicamentos homeopáticos.

Durante o Seminário RENAME promovido pela CEME, Fiocruz e OPAS/OMS em março de 1997, afirmou ZUBIOLI, que o governo pode e deve regulamentar a Seguridade Social em relação ao reembolso dos gastos com medicamentos, garantindo a disponibilidade e 0 acesso universal a ele. Este reembolso ocorreria de forma variável, desde 100\% para medicamentos essenciais, passando por $80 \%, 50 \%$ e até o nãoreembolso. 0 governo, assessorado por entidades médicas e farmacêuticas, estabeleceria critérios para classificar os medicamentos dentro dos diversos grupos ${ }^{(134)}$.

ULLMANN, sanitarista americano, cita relatório da Seguridade Social francesa de 1991, mostrando que o serviço médico homeopático custava aproximadamente $50 \%$ do valor do serviço médico convencional. 0 valor dos medicamentos homeopáticos era menos que um terço quando comparado com os alopáticos. O Hospital Homeopático de Bristol, na Inglaterra, que atende a 3.000 pacientes ao ano, tem um custo total da farmácia de US $\$ 23.000,00$. O custo médio da prescrição foi de US\$5,13 incluindo as despesas de pessoal. Considerando apenas o custo direto do medicamento, este valor diminuia para US $\$ 2,50$, atingindo, no mínimo, $40 \%$ menos do que o necessário para ressarcir qualquer outro tipo de medicamento na Inglaterra ${ }^{(127)}$. 
Como este autor propõe a automedicação para problemas mais comuns e menos sérios de saúde, afirma que o uso de Homeopatia não só reduz os custos relativos ao médico e ao medicamento, mas também a necessidade de procurar serviços de atendimento médico. Segundo ele, a maior parte dos homeopatas encorajam o "auto-cuidado" de pequenas doenças agudas, o que não ocorre no Brasil, especialmente entre os médicos unicistas. Para ULLMANN, casos crônicos requerem medicamento constitucional, e portanto um homeopata experiente. Além disso, é necessário um médico para prevenção e promoção da saúde, desordens genéticas, cuidados de gestantes, sintomas recorrentes e sintomas agudos sérios ${ }^{(127)}$.

Para ilustrar como o aspecto "quantidade de medicamento" pode ser ponderado de forma diversa quando consideramos medicamentos homeopáticos, tomemos da história a referência de MURE, introdutor da Homeopatia em nosso país, que afirmava iniciar o tratamento de lotes inteiros de escravos com apenas 1 glóbulo de medicamento dissolvido em 1 litro de água, e distribuído em pequenas colheradas a todos os doentes. $E$ acrescentava:

".... a grande massa de clínicos gerais elegem um meio-termo e declaram com aquela empáfia, que as vezes chamamos de bomsenso popular, que todas as diluições (que chamamos de potência neste trabalho) eram indiferentes e, desde que o medicamento fosse verdadeiramente homeopático poder-se-ia - cada qual conforme melhor the aprouvesse - empregar qualquer diluiçáo começando-se pela tintura-mãe, e terminar onde Deus quisesse. Essa estranha opinião foi năo só propalada, como reproduzida de incontáveis maneiras. Por mais surpreendente que possa parecer, senhores, ela ainda é hoje em dia o apanágio de $75 \%$ dos clínicos homeopáticos" (100)

Percebemos acima alguns aspectos interessantes para nosso trabalho, 
coma a já citada noção de quantidade, que pode ser completamente alterada quando consideramos medicamentos homeopáticos. Seguindo este raciocínio e apropriando-se da técnica de MURE, o custo dos medicamentos homeopáticos poderia tornar-se fator desprezivel, e portanto de máxima importância quando de sua utilização em serviços públicos. É claro que farmácias homeopáticas privadas são estabelecimentos que devem obedecer a critérios de qualidade e padronização de produção, embalagem e rotulagem, impostos pela legislação sanitária, que especificam rigidamente as potências dos medicamentos e agregam custos ao seu produto, além do lucro inerente do negócio. Porém compreende-se que, uma vez que a dinamizaçăo - isto é, o desenvolvimento do poder medicamentoso das substâncias - é realizada através de diluições, farmácias de manipulação bem administradas, pertencentes a serviços públicos homeopáticos, podem produzir medicamentos homeopáticos com custos baixos, quando comparadas com aquelas que dependam da presença material das substâncias ativas.

Outro ponto a ser abordado, e que advém da citação de MURE, é a possibilidade de que não importariam as potências. Poder-se-ia afirmar que este pensamento não mais ocorre na atualidade, não tivesse sido expressado por MARIN, coordenador da Comissão de Pesquisas da AMHB, no último Congresso Brasileiro de Homeopatia, no final de 1988. Acreditamos que esta idéia seja relativa, isto é, o medicamento correto prevalece sobre a grandeza da potência, que teria portanto uma importância secundária quando comparada com a substância que the deu origem ${ }^{(100)}$.

\section{4 - Aspectos vulneráveis na questão do medicamento homeopático:}

Quando analisamos os requisitos para enquadramento de drogas na RENAME (QUADRO 13), verificamos que dois pontos podem dificultar a 
inclusão dos medicamentos homeopáticos: comprovação de sua eficácia clínica, e dificuldades para estabelecer especificações e métodos de Controle de Qualidade. Com certeza, estes aspectos têm prejudicado a aceitação desta terapêutica entre os praticantes da Medicina alopática, com reflexos sobre os responsáveis pela administração dos serviços públicos de saúde.

A estes poderiamos somar ainda a eficiente ação de marketing da indústria farmacêutica, que tem como consequência dificultar espaço para a divulgação de outras formas terapêuticas. Em princípio, 0 fato do medicamento homeopático poder ser classificado como genérico, não possuindo marcas ou nomes fantasia, classifica-o como um alvo pouco interessante para a indústria farmacêutica, e como consequência diminui custos e a imposição de prescrições geradas por propaganda. Ainda que a maioria das substâncias de origem dos medicamentos seja importada, é necessária uma quantidade diminuta delas, que passam a ser dinamizadas com veículos e diluentes produzidos em nosso país.

A necessidade de uma consulta mais longa requerida pelo homeopata, ainda que favorável ao paciente, é um aspecto que prejudica a cobertura de atendimento médico da população, sendo, como consequência, pouco apreciada pelos coordenadores dos serviços, ainda que a médio prazo, a Homeopatia venha a economizar verbas. A AMHB preconiza 2 consultas homeopáticas por hora, enquanto que os alopatas atendem a 4 pacientes por hora ${ }^{(11,42,59)}$.

Em relaçăo à comprovação de atividade clínica, podemos citar, entre outros, trabalhos da pesquisadora francesa Madeleine BASTIDE, apresentados entre nós em seminário na APH, bem como em curso durante o Congresso Brasileiro de Homeopatia de 1998. Sua pesquisa demonstra, de forma reprodutível, a ação de substâncias extremamente diluídas, além do número 
de Avogrado, em organismos vivos, fornecendo evidências experimentais do observado na prática dos clínicos homeopatas ${ }^{(25)}$.

Existem ainda diversos artigos sobre casos clínicos publicados em revistas internacionalmente reconhecidas, assim como apresentados em cursos e congressos. Trata-se porém de descrições de um valor secundário, quando o objetivo é propor o tratamento homeopático para populaçōes ${ }^{(59,63,79,108,109)}$

Trabalhos clínicos realizados em grupos de individuos são menos freqüentes, sendo que podemos citar o de MOREIRA NETO, que utilizou um sistema de graus para classificar a evolução clínica da clientela, demonstrando que a partir da 3a. consulta até a 9a. foi observada melhora e/ou desaparecimento de sintomas em cerca de $70 \%$ da população atendida. Na 10a. consulta, esta frequêencia passou a ser de $90 \%$. A partir da 5 a. consulta não mais foi observada piora dos sintomas ${ }^{(99)}$.

Com certeza, a Homeopatia beneficiar-se-ia de uma maior quantidade de trabalhos deste tipo, que poderiam até mesmo comparar grupos semelhantes, tratados por terapêuticas distintas, em um mesmo serviço.

Em relação à discussão sobre a qualidade do medicamento homeopático, temos tanto $\mathrm{o}$ aspecto de avaliação ligado à sua atividade clínica, quanto aqueles relacionados à sua produção.

Existiriam diferenças relacionadas à ação entre medicamentos produzidos por diferentes farmácias ou laboratórios industriais homeopáticos? Respondendo a esta pergunta, ULLMANN afirmou que os medicamentos homeopáticos são geralmente considerados como genéricos, já que supostamente são feitos da mesma forma. Podem porém existir diferentes niveis de qualidade e, uma vez que não existem levantamentos que comparem os padrōes de fabricação, os homeopatas tendem a comprar 
medicamentos homeopáticos de empresas que estão no mercado há longo tempo ${ }^{(127)}$.

Podemos acrescentar que este argumento não é uma garantia absoluta de que o medicamento apresente uma boa atividade clínica, ainda mais quando lembramos que esta atividade depende não só de aspectos do preparo, mas essencialmente da correta indicação do medicamento.

O GEPRO de Práticas Alternativas de Saúde, preocupado com a garantia da qualidade de medicamentos homeopáticos, estabeleceu, em 1988, a Comissão de Práticas Alternativas de Saúde, que infelizmente, apesar de ter-se reunido durante mais de um ano, não viu seu trabalho tornar-se um texto oficial.

Alguns autores têm questionado a qualidade dos medicamentos homeopáticos, especialmente em função de suas substâncias de origem. ADLER acrescenta mesmo que a pesquisa clínica poderia obter benefícios, possibilitando a comparação dos resultados clínicos, se ocorresse a padronização farmacêutica ${ }^{(4,22,23,24,54,67)}$.

A União Européia, através da Diretiva de 1992, tem trabalhado para harmonizar as regulamentaçōes dos medicamentos homeopáticos, em relaçăo à sua produção, registro e utilização. O Mercosul deverá seguir os mesmos passos no futuro.

Diferente do medicamento alopático, quase todo ele produzido por grandes indústrias farmacêuticas transnacionais, e submetido a rígidas especificaçōes técnicas e métodos de Controle de Qualidade, o medicamento homeopático é produzido em farmácias, e não é, nem pode ser controlado em sua forma final, mas apenas em relação às suas matérias primas e processo de fabricação. A produção do medicamento quase que 
exclusivamente realizada nas muitas farmácias homeopáticas espalhadas pelo país, assim como o não completo seguimento às normas estabelecidas pela legislação, favorecem a pouca padronização do medicamento homeopático, ainda que novas resoluções da Agência Nacional de Vigilância Sanitária venham a estabelecer normas e Roteiros de Inspeção para estes estabelecimentos ${ }^{(6)}$.

Especificações para as substanncias de partida, sejam elas vegetais, animais ou minerais, bem como das tinturas-mãe, e ainda das substâncias inertes utilizadas como veículo ou diluente, e aquelas do processo de fabricação são todas possiveis de ser estabelecidas, seja com o auxílio das Farmacopéias Homeopáticas ou outras fontes bibliográficas. O produto final, entretanto, freqüentemente bastante diluído, só pode beneficiar-se de especificações e métodos de Controle de Qualidade que podemos considerar como fundamentados em exclusōes. Assim, por exemplo, uma solução alcoólica de Chamomilla $30 \mathrm{CH}$ pode ter seu teor alcoólico, sua coloração e sua transparência medidos, seu sabor e odor avaliado, e acima de tudo, deve ser incolor e translúcida. Nenhum destes parâmetros garantem, porém, tratar-se de 30 diluições feitas na proporção de 1:100, a partir de uma tintura-mãe da parte indicada da planta correta, cultivada e coletada de maneira adequada. Este fator, torna a confiança no produtor do medicamento homeopático, no caso o farmacêutico, um aspecto da maior importância. Em resumo, o controle se dá através das matérias primas de origem, dos veículos e excipientes inertes, e do controle do processo, e em todos estes passos a atividade farmacêutica é imprescindível.

$\mathrm{Na}$ maior parte dos serviços estudados, notou-se fragilidades em sua estrutura. Tratando-se de serviços públicos, pontos mais frágeis existem também para aqueles de atendimento médico alopático, que dependem de decisões políticas. Porém, uma vez que a Homeopatia já apresenta aspectos anteriormente apontados que dificultam sua implantaçăo, esta 
dependência torna-a ainda mais susceptivel. É aí que têm lugar as soluçōes individuais, como a grande dedicação observada pelos coordenadores e profissionais que participam dos diversos serviços estudados. São médicos e farmacêuticos que viajam dezenas de quilômetros para atender em um local onde existe empenho para a implantação e manutenção da Homeopatia; farmácias que doam medicamentos a pacientes carentes. $O$ sucesso dos serviços parece depender da persistência, do empenho, quase da devoção e da paixão dos envolvidos. É claro que todos os serviços, médicos ou não, observam melhores resultados se existe dedicação, mas este aspecto parece ser mais importante para a implantação e o bom andamento de serviços homeopáticos.

Mesmo após termos apontado estas dificuldades, que podem prejudicar sua plena aceitação, afirmamos que a Homeopatia preenche suficientemente os critérios necessários para adoção pelo sistema público. Esta adoção já está garantida desde 1988, quando da publicação da CIPLAN 4. Naquela época, existia a idéia de produção centralizada de medicamentos para fornecimento gratuito aos serviços de saúde, a partir de uma relação com 60 substâncias dinamizadas na $30 \mathrm{CH}$, apresentadas na forma líquida. No ano seguinte, a CIS/SP aprovou Contrato de Prestação de Serviços de Aviamento de Receitas Homeopáticas e garantiu o fornecimento gratuito de medicamentos aos serviços públicos da época, através do estabelecimento de convênios com farmácias. Estes dados mostram existir, da parte do governo, a preocupação com o fornecimento do medicamento aos serviços de saúde.

Outro ponto já considerado é que a população aceita e aprecia o atendimento médico homeopático. Seu custo é acessivel e pode tratar uma ampla variedades de patologias, crônicas e agudas, que acometem as comunidades. MOREIRA NETO, estudando um dos serviços desta pesquisa, concluiu que $\mathrm{O}$ atendimento homeopático em Unidade Básica de 
Saúde (UBS) é viável, com utilização da própria estrutura física e pessoal do Centro de Saúde, custo adequado, e satisfação e confiança da clientela. Finalmente, afirma que a Medicina Homeopática deve ser implantada em um maior número possível de unidades do SUS ${ }^{(91,99)}$.

As fichas clínicas constituem-se em importante ferramenta para coleta e estudo de dados de atendimento homeopático. Sua importância deve ser ressaltada e estimulada sua discussão, estudo e correto preenchimento. Existe um grupo preocupado com este aspecto na $A M H B$, que discute o tema e apresenta propostas em fóruns realizados em congressos nacionais e internacionais. 


\section{6 - CONCLUSÕES:}

Após a realização da pesquisa e discussão acima efetuada, podemos concluir que:

1. A Homeopatia preenche suficientemente os critérios necessários para sua adoção pelo sistema público, embora alguns fatores possam dificultar sua plena aceitação. A comprovação de eficácia deve ser melhorada. Da mesma forma o desenvolvimento de métodos de Controle de Qualidade seria uma medida importante.

2. Deve haver fornecimento do medicamento homeopático, através de estoque de medicamentos, farmácia estabelecida no local do atendimento médico ou ainda farmácia conveniada, situada próxima ao serviço, e sendo o medicamento financiado pelo custeio coletivo.

3. É possível montar uma lista básica com um número limitado de medicamentos, com potência, escala, forma farmacêutica e posologia definidos, para atendimento de um grande número de patologias, inclusive doenças crônicas.

4. Os sistemas públicos de atendimento homeopático são frágeis, tanto por serem públicos, e mais especialmente por serem homeopáticos.

5. A base de dados disponivel através das fichas clínicas, apesar de ser excelente fonte de informaçōes sobre o atendimento homeopático, é fraca, e deve ser melhorada. É importante que o clínico tenha consciência e cuidados com esta importante ferramenta para o estudo da Homeopatia. 


\section{7 - RECOMENDAÇÕES}

Considerando as conclusões da pesquisa, propomos as seguintes recomendações:

1. que sejam desenvolvidas listas básicas de medicamentos homeopáticos por órgãos responsáveis por propostas de implantação de políticas de saúde em serviços de atendimento médico homeopático.

2. que os sistemas públicos de atendimento homeopático sejam fortalecidos; que sejam avaliados através de critérios que levem em consideração suas características, possibilitando sua manutenção, apesar de alterações políticas.

3. que sejam realizados mais estudos sobre a eficácia clínica de tratamento homeopático em populações, bem como sobre a utilização do medicamento homeopático;

4. que a importância dos dados armazenados em fichas clínicas seja enfatizada junto aos médicos, veterinários e cirurgiōes-dentistas, incentivando-os a melhorar sua qualidade e organização, a fim de serem utilizados em pesquisas necessárias para a melhor compreensão dos tratamentos homeopáticos e aceitação desta terapêutica. 


\section{7 - REFERÊNCIAS BIBLIOGRÁFICAS:}

1. [Anonymus] Faits et Chiffres - Homéopathie, une pratique à histoires. La Recherche 1998; 310: 75.

2. [Anonymus] Folha de São Paulo 1998 ago 26.

3. Adames LAB. Medicamentos essenciais: gestão nos serviços públicos de saúde fundamentada no quadro nosológico. Divulg. Saúde Debate 1997;18: 34-42.

4. Adler UC et al. Técnicas de dinamizaçăo. Divergências e necessidade de padronização. Revista de Homeopatia (São Paulo) 1992; 57(1-4):24-8.

5. Adler UC, Ambrósio E, Anelli IM, Cappello E, Cesar AT, Guimarăes EC. A strict definition of homoeopathy according to HAHNEMANN. Brit Homeop J 1996; 96:79-82.

6. Agência Nacional de Vigilância Sanitária. Portaria $n^{\circ}$ 53, de 5 de maio de 1999 (consulta pública). Diário Oficial da União 1999; 6 de maio (http://uww.dou.gov.br)

7. Associação Brasileira de Farmacêuticos Homeopatas. Informativo. Ano VI, $n^{\circ} 13$, janeiro 1998, p.5.

8. Associaçăo Brasileira de Farmacêuticos Homeopatas. Manual de Normas Técnicas para Farmácia Homeopática. Rio de Janeiro; 1992.

9. Associaçăo Brasileira de Farmacêuticos Homeopatas. Manual de Normas Técnicas para Farmácia Homeopática. 2a. ed. Rio de Janeiro; 1995.

10. Associação Médica Homeopática Brasileira e Associação Médica Brasileira. Convênio de 8 de junho de 1989.

11. Associaçăo Médica Homeopática Brasileira. Comissão de Saúde Pública. Proposta para implantaçăo de atendimento homeopático na rede pública. Revista de Homeopatia (São Paulo) 1995; 60 (2): 35-9.

12. Associaçăo Médica Homeopática Brasileira. Gazeta Homeopática. Ano 6, n 16 , março 1998, p.6.

13. Associação Paulista de Homeopatia. Estatuto.

14. Associação Paulista de Homeopatia. Informativo. Ano 8, no. 61, março-abril 1996, p.12.

15. Associação Paulista de Homeopatia. Informativo. Ano $9, n^{\circ} 71$, novembrodezembro 1997, p. 9. 
16. Associaçåo Paulista de Homeopatia. Informativo. Ano 9, $n^{\circ} 72$, janeiro-fevereiro 1998, p.18.

17. Association Française des Enseignants de Pharmacie Galénique. Galénica vol. 16. Médicaments homéopathiques. Notions pratiques de pharmacie homéopathique. Paris: Technique et Documentation; 1986.

18. Astin JA. Why patients use alternative medicine. JAMA 1998; 279(19):1548-53.

19. Banerjea SK. Homoeopathy around the world. New Delhi: B. Jain; 1991.

20. Baptista AL. Relatório da reunião da CEME de 22/8/89, Brasília, 1989.

21. Baptista AL. Relatório da reunião da CEME de 31/1/89, Brasília, 1989.

22. Barthel P. Das Vermăchtnis HAHNEMANNs - die Qualităt der Homరopathischen Arznei. Zeitschrift für klassische Homöopathie. Trad. ingl. A.R.Meuss, FIL, MTA; 1993.

23. Barthel P. O legado de HAHNEMANN: as potências $Q$ (LM). Revista de Homeopatia (São Paulo) 1993; 58(1):13-23.

24. Barthel P. O legado de HAHNEMANN: ascençăo e queda de Bryonia alba. Revista de Homeopatia (São Paulo) 1994; 59(1):37-9.

25. Bastide M, editora. Signals and Images. Dordrecht: Kluwer; 1997.

26. Baur J. Avatars et aventures du remede homeopatique. Ediçăo do autor.

27. Bellavite P, Signorini A Homeopathy. A frontier in medical science. Berkeley: North Atlantic. 1995.

28. Benveniste J. Um outro mundo conceitual.Revista de Homeopatia (Săo Paulo) 1988; 53(3):113.

29. Berman BM, Hartnoll SM, Singh BB, Singh BK. Homeopathy and the US primary care physician. Brit Hom J 1997; 86:131-8.

30. Bermudez J. Medicamentos e assistência farmacêutica na agenda da Saúde. Boletim SOBRAVIME 25, abril junho 1997, pág. 7.

31. Bertolli Filho C. A doutrina homeopática no Brasil: os anos 30. Revista de Homeopatia (São Paulo) 1988; 53(2):74-82.

32. Bertolli Filho C. Homeopatia e espiritismo: em tomo do imaginário social. Revista de Homeopatia (São Paulo) 1990; 55(3):72-8.

33. Boiron Reference Guide Lyon: Boiron; 1992.

34. Boy D. Qual a explicaçăo sociológica para a expansăo das chamadas medicinas 
alternativas? In: Witkowski N, coordenador. Ciência e tecnologia hoje. São Paulo: Ensaio; 1995, pág.100-2.

35. Bruno CG. Report on the homeopathic activities developed in Brazil. 1990/1992. Relatório para a reunião anual do Comitê Executivo da Liga Médica Homeopática Internacional, de 1992, em Colonia, Alemanha.

36. Campos VF. TQC - Controle da Qualidade Total. 3a. ed. Fundaçăo Christiano Ottoni., Universidade Federal de Minas Gerais, Escola de Engenharia;1992.

37. Carlini EA. et al. Efeito hipnótico de medicação homeopática e do placebo. Avaliaçăo pela técnica de "duplo-cego" e "cruzamento". Rev Ass Med Brasil, 33:83-8.

38. Cavalcanti JRH. Um olhar sobre a Rename 97. Boletim SOBRAVIME 25, abril junho 1997, pág. 6-7.

39. Central de Medicamentos. Serviço Público Federal. Ronei Edmar Ribeiro. Portaria 119 1988; 9 de setembro.

40. Cesar AT, Casellato CM. Consideraçőes estatísticas sobre receitas aviadas durante dois meses em uma farmácia homeopática de Săo Paulo [Apresentado como tema livre no Congresso Brasileiro de Homeopatia; 1986; Săo Paulo]

41. Cesar AT. Estudo de prescrições em farmácias homeopáticas da cidade de São Paulo [Apresentado no Congresso Brasileiro de Homeopatia; 1998 nov; Gramado, Brasil].

42. Comissão de Saúde Pública da Associaçăo Médica Homeopática Brasileira. V Forum Nacional de Homeopatia na Rede Pública [Apresentado no Congresso Brasileiro de Homeopatia; 1998 out 29; Gramado, Brasil].

43. Comissăo Interinstitucional de Saúde de São Paulo. Deliberação no. 81 de 29/11/89: aprova as diretrizes gerais para o atendimento em Homeopatia. Diário Oficial do Estado de São Paulo, São Paulo. 1989; 29 nov., p.23.

44. Comissăo Interministerial de Planejamento e Coordenaçăo. Resoluçăo no. 4 de 8/3/88: implanta a prática da Homeopatia nos serviços públicos de saúde. Diário Oficial da Uniăo, Brasília. 1988; 11 mar., p. 3996.

45. Comissión de Sistemas Altemativos de Medicina. La medicina alternativa en los Países Bajos. Foro Mundial de Salud; 1982. 3:234-9.

46. Conselho da Comunidade Comum Européia. Directiva 92/73/CEE do Conselho. De 22 de setembro de 1992. Jornal Oficial das Comunidades Européias no. $L$ 297/8. 1992; 13/outubro. 
47. Conselho Federal de Farmácia. Resolução 232. 6 de maio de 1992.

48. Conselho Federal de Farmácia. Resoluçăo 267. 9 de fevereiro de 1995.

49. Conselho Federal de Farmácia. Resolução 335. 17 de novembro de 1998.

50. Conselho Federal de Medicina. Resolução 1000/80. 4 de junho de 1980. Acréscimo da Homeopatia à relaçăo de especialidades reconhecidas pelo CFM. Diário Oficial da Uniăo (Seçăo I - Parte II), Brasília. 21 de julho de 1980.

51. Coulter HL Divided legacy: a history of the schism in medical thought. Berkeley: North Atlantic; 1982. vol. 1-3.

52. Coulter HL Homoeopathic Science \& Modern Medicine. Berkeley: North Atlantic; 1981.

53. Davenas E, Beauvais JA, Oberbaum $M$ et al. Human basophil degranulation triggered by very dilute antiserum against IgE. Nature $1988 ; 333: 816-18$.

54. Dellmour F. A importância da trituraçăo C3 no preparo de medicamentos homeopáticos. Revista de Homeopatia (São Paulo) 1994; 59(2):41-5.

55. Dey SP. Role of Homoeopathy in National Health Programme. Publ. Dr. kankar Bhattacharya. Howrah; 1988.

56. Dolisos. Nomenclature homeopathique. França: Similia.

57. Dudgeon RE. O princípio homeopático em medicina antes de HAHNEMANN. Revista de Homeopatia (São Paulo) 1994; 59(2):8-18.

58. Eisenberg DM, Kessler RC, Foster C, Norlock FE, Calkins DR, Delbanco TL. Unconventional medicine in the United States. N Engl J Med 1993; 328:246-52.

59. European Committee for Homoeopathy. Homoeopathy in Europe. 1994.

60. Farmacopéia Homeopática Brasileira. 2a. ed. Săo Paulo: Andrei; 1997.

61. Farmacopéia Homeopática Brasileira. Săo Paulo: Andrei; 1977.

62. Ferley JP, Smirou D, D'Adhemar D, Balducci F. A controlled evaluation of homoeopathic preparation in the treatment of influenza-like syndromes. $\mathrm{Br} \mathrm{J}$ Clin Pharmacol. 1989; 27:329-35.

63. Fisher P, Greenwood A, Huskisson EC, Turner P, Belon P. Effect of homoeopathic treatment on fribrositis (primary fibromyalgia). Br Med J. 1989; 299:365-6.

64. Fontes $\mathrm{OL}$. A educaçăo biomédica em transiçăo conceitual: um enfoque pósmoderno. Piracicaba; 1997. [Tese de doutorado - Universidade Metodista de Piracicaba]. 
65. Froede C. A Homeopatia no Serviço de Saúde Pública de Brumadinho. São Paulo; [Monografia para conclusão do curso de Especializaçăo em Farmácia Homeopática na Associação Paulista de Homeopatia].

66. Fulder S, Munro RE. Complementary medicine in the United Kingdom: patiens, practitioners and consultations. Lancet 1985;11:542-6.

67. Gurdjons B. O preparo de remédios homeopáticos autênticos. Revista de Homeopatia (São Paulo) 1995; 60(1):36-8.

68. Hahenmann S. Materia Medica Pura. New Delhi: B. Jain; 1994.

69. Hahnemann S. Ensaio sobre um novo principio para se averiguar os poderes curativos das drogas. Revista de Homeopatia (Săo Paulo) 1994; 59 (3-4): 32-65.

70. Hahnemann S. Organon der Heilkunst - Organon da arte de curar, 6a. ed. Ribeirão Preto: Museu de Homeopatia Abrahão Brickmann; 1995.

71. Hahnemann, S. The Chronic Diseases. 1989 reprint. New Delhi: B. Jain, 1989. 2v.

72. Homöopathisches Arzneibuch. 1. Ausgabe. Stuttgart: Deutscher Apotheker Vergag; 1978.

73. Homøopathisches Arzneibuch. 1. Nachtrag zur Gesamtausgabe. Stuttgart: Deutscher Apotheker Vergag; 1991.

74. IAKAP. Manual Clínico do ambulatório Médico Hahnemanniano. Săo Paulo: Robe; 1993.

75. IDEC, Instituto Brasileiro de Defesa do Consumidor. Guia dos Planos de Saúde. Consumidor S.A. 1996; 9, junho, p. 7-22.

76. Jacobs J, Jiménez M, Gloyd S, Gale JL, Crothers D. Treatment of acute chilhood diarrhea with homeopathic medicine: a randomized clinical trial in Nicaragua. Pediatrics 1994; 93(5):719-25.

77. Kayne, SB. Homoeopathic Pharmacy. An introduction and handbook. Edinburgh: Churchill Livingstone; 1997.

78. Kishore J. Homeopathy: the Indian experience. World Health Forum 1983; 4:1057.

79. Kleijnen J, Knipschild P, Riet G. Clinical trials of homoeopathy. Br Med J 1991; 302:316-23.

80. Lackridge B. Homeopathy in primary care. Br Hom J 1998; 87(2):117-20. [Abstracts de JM English]. 
81. Lewkowicz $L$. Cientistas franceses demonstram a atividade biológica das diluições infinitesimais. Revista de Homeopatia (Săo Paulo) 1988; 53(3):107.

82. Liga Médica Homeopática Internacional. Secretaria de Farmácia. Relatórios anuais 1990-98.

83. Lima AMA, Pitarello M, Rodrigues PRA, Beutner R, Bergo SM. Observaçס̃es clínicas sobre a ação de medicamentos homeopáticos em lesões por papiloma vírus humano (Policlínica III da Secretaria Municipal de Saúde de Campinas). Revista de Homeopatia (São Paulo) 1997; 62(1-2): 3-5.

84. Luz MT. A implantaçăo da Homeopatia no Brasil. Ciênc. Hoje 1988; 7(9):62-3.

85. Luz MT. História político-institucional da Homeopatia no Brasil (século $X \mid X$ ): a implantaçăo. In: Luz MT, org. A questão da Homeopatia. Rio de Janeiro: Escola Nacional de Saúde Pública/Associaçăo Brasileira de Pós-Graduação em Saúde Coletiva;1987.

86. Luz MT. História político-institucional da Homeopatia no Brasil (1840-1990). Saúde Debate 1991; 30: 35-9.

87. Luz, MT. A arte de curar versus a ciência das doenças: história social da Homeopatia no Brasil. São Paulo: Dynamis; 1996.

88. Maravieski M. A Homeopatia e a saúde do escolar. Florianópolis, 1997. [Apostila].

89. Meirelles AS. Pequena história da Homeopatia com suas repercussőes na cidade do Rio de Janeiro, no período de 1886 a 1986. Rev. Bras. Homeopatia 1991; 1(1):6-11.

90. Mendez A Tratado de Farmacotecnica Homeopática. Buenos Aires, 1997.

91. Mendicelli VLSL. Homeopatia: percepção e conduta de clientela de postos de saúde. São Paulo; 1994. [Tese de doutorado - Faculdade de Saúde Pública da USP].

92. Millet A. Recettes artisanales pour une industrie légère. La Recherche 1998; 310: 76.

93. Ministério da Previdência e Assistência Social. Resoluçăo CIPLAN no. 4, de 8 de março de 1988.

94. Ministério da Previdência e Assistência Social. Resolução INAMPS no. 112 de 21/1/86: implantaçăo do programa de Homeopatia. Bol. Serv. INAMPS 1986; Brasília, 28 jan. Anexo II. 
95. Ministério da Saúde, Central de Medicamentos Projeto de Homeopatia.

96. Ministério da Saúde. Portaria n 507/GM. Diário Oficial da União 1999; 04 maio, Seção 1, p. 16-29 (republicação).

97. Ministério da Saúde. Portaria SVS no. 2543, de 14/12/95: institui Grupo Assessor Técnico-Científico em Medicinas não-Convencionais (GATC-MnC). Diário Oficial da União 1996; 16 fev, seção 1, pág. 2726.

98. Ministry of Health, Government of India. Homoeopathic Pharmacopoeia of India. Delhi, 1971.

99. Moreira Neto G. Homeopatia em Unidade Básica de Saúde (UBS): um espaço possível. São Paulo; 1998. [Dissertação de mestrado - Faculdade de Saúde Pública da USP].

100. Mure B. Patogenesia Brasileira. Săo Paulo: Roca; 1999.

101. Nicholls PA. Homoeopathy and the medical profession. London: Croom Helm; 1988.

102. Pharmacopée Française. Préparations homéopathiques. 8a. ed., 1965.

103. Poitevin B. Mecanismos de ação dos medicamentos de uso homeopático. Dados recentes e hipóteses. 1a. parte: mecanismos físico-químicos. Revista de Homeopatia (São Paulo) 1994; 59(1):24-30.

104. Poitevin B. Mecanismos de ação dos medicamentos de uso homeopático. Dados recentes e hipóteses. 2a. parte: mecanismos biológicos. Revista de Homeopatia (Såo Paulo) 1994; 59(2):27-31.

105. Preparados Homeopáticos. Farmacopéia do Chile.

106. Presidência da República. Medida Provisória 1710-5 de 30 dez.1998 que cria a ANVS. Diário Oficial da União, Brasília, 31 dez. 1998 (transformada na Lei 9782 de 26 jan. 1999)

107. Quinn M. Research on homoeopathy and chemistry. Are le crystals the missing link? Homoeopathic Links, 1998; vol 11(3):126-7.

108. Reilly D, Taylor MA, Beattie NGM, Campbell JH, McSharry C, Aitchison TC, Carter R, Stevenson RD. Is evidence for homeopathy reproducible? Lancet 344 (December 10): 1601, 1994.

109. Reilly DT, Taylor MA, McSharry C, Aitchison T. Is homoeopathy a placebo response? Controlled trial of homoeopathic potency, with pollen in hayfever as model. Lancet 1986; ii:881-5. 
110. Reis A O valor do uso racional de medicamentos. Boletim SOBRAVIME 25, abril junho 1997, pág. 10-11.

111. Resch G. Gutmann V. Scientific foundations of homeopathy. English ed. Germany: Barthel \& Barthel; 1987.

112. Ribeiro Filho A. Novo repertório de sintomas homeopáticos. São Paulo: Robe; 1996.

113. Schiff M. Un cas de censure dans la science. L'affaire de la mémoire de l'eau. Paris: Albin Michel, Paris;1994.

114. Secretaria de Estado da Saúde de São Paulo. Portaria SS-CG no. 003 de 3/3/86: constitui grupo de trabalho. Diário Oficial do Estado de São Paulo, São Paulo, 1986; 6 mar: 98.

115. Secretaria de Estado da Saúde de São Paulo. Resoluçăo SS no. 21 de 29/1/88: constitui Grupo Especial de Desenvolvimento do Programa (GEPRO) Práticas Alternativas de Saúde. Diário Oficial do Estado de Săo Paulo, São Paulo, 1988; 6 fev: 20.

116. Secretaria de Estado da Saúde de São Paulo. Resolução SS-84, de 30 de maio de 1989, constitui a Comissåo de Práticas Alternativas de Saúde.

117. Secretaria do Estado da Saúde de São Paulo. Resoluçăo SS-90. 1989, de 1 de junho, aprova Diretrizes Gerais para o atendimento em Homeopatia no SUDS/SP.

118. Shipley $M$, Berry H, Broster $\mathbf{G}$ et al. Controlled trial of homoeopathic treatment of osteoarthritis. Lancet 1983; i:97-8.

119. Silva JBT, Sposati MCC, Carlovich Filho J, Cudizio O. Atendimento homeopático no Centro de Saúde da Barra Funda, S.P. Revista de Homeopatia (Såo Paulo) 1988; 53(4):126-30.

120. SINDUSFARMA - Sindicato da Indústria Farmacêutica do Estado de Săo Paulo. Projeto enviado para o Ministério da Sáude sobre registro de medicamentos homeopáticos.

121. Soares JCRS. Antropologia farmacêutica: campo a ser constituído no país. Boletim SOBRAVIME 25, abril junho 1997, pág. 15-16.

122. SOBRAVIME - Sociedade Brasileira de Vigilância de Medicamentos. Boletim 1998; 28:1-4.

123. Sub-committee Pharmacology, Materia medica and Pharmacopoeia. European Committee for Homoeopathy. Dellmour F. Report. Meeting London, 
15.march 1999.

124. Teixeira MZ. Semelhante cura semelhante. São Paulo: Petrus; 1998.

125. The Pharmacopoeia Convention of the American Institute of Homoeopathy. Homoeopathic pharmacopoeia of the United States. 8a. ed. Falls Church: Otis Clapp\&Son; 1979.

126. Thomas KJ, Carr J, Westlake L, Williams BT Use of non-ortodox and conventional health care in Great Britain. BMJ 1991; 302:207-10.

127. Ullmann D. The consumer's guide to homeopathy. New York: Tarcher Putnam; 1995.

128. Vannier L. A idéia da Homeopatia na história. Revista de Homeopatia (São Paulo) 1994; 59(1):9-15.

129. Vieira GR. Homeopatia e Serviço Público Brasileiro [Apostila apresentado no XIX Congresso Brasileiro de Homeopatia, 1988, Gramado].

130. Vithoulkas G. Homoeopathy. In: Bannermann RH, Burton J, Wen-Chieh C. coord. Traditional medicine and health care coverage. Geneva, World Health Organization; 1983, p.110-5.

131. World Health Organization. Cómo investigar el uso de medicamentos en los servicios de salud.

132. World Health Organization. How to investigate drug use in communities. Geneve; 1992.

133. Yasgur J. Homeopathic dictionary and holistic health reference. $4^{\circ} \mathrm{ed}$ Greenville: Van Hoy; 1998.

134. Zubioli A Uma política de medicamentos para o Brasil. Boletim SOBRAVIME 25, abril junho 1997, pág. 3-5. 


\section{9 - ANEXOS:}

Roteiro para coleta de dados:

O roteiro preliminar dos dados a serem coletados em visitas, entrevistas, formulários e questionários foi o seguinte:

- número de médicos consultantes na unidade

- número total de horas semanais de atendimento

- número de médicos homeopatas na unidade

- número total de horas semanais de atendimento

- duração das consultas

- descrição da população atendida na unidade quanto a: número, faixa etária, sexo, ocupação, classificação quanto a renda

- principais diagnósticos

- porcentagem de retorno

- forma de encaminhamento dos pacientes para o serviço de Homeopatia: a partir de outros serviços ou por demanda espontânea

- utilização de outros recursos terapêuticos pelos médicos homeopatas? Se sim, quais?

- em relação à obtenção dos medicamentos homeopáticos eles são: preparados no próprio estabelecimento, comprados de farmácia homeopática e estocados na própria unidade, comprados pelo paciente em farmácia homeopática ou outra forma?

- no caso de fornecimento pelo serviço, são atendidas todas as prescriçōes?

Se não, por quais motivos?

- no caso de não fornecimento do medicamento ao paciente, qual a orientação que ele recebe

- existem critérios pré-estabelecidos para compra de medicamento?

- caso existam, quais são eles? Relacionados ao custo, a um tipo específico de preparo ou outros?

- quem é responsável pelo estabelecimento destes critérios: o responsável 
pelas compras, o médico homeopata, o farmacêutico ou outro profissional?

- ao médico homeopata: Existe preocupação com a qualidade dos medicamentos homeopáticos? Qual sua opinião a respeito?

- existem diferenças em funçăo de diferentes fornecedores? Se sim, em que sentido?

- o fornecimento de medicamentos é satisfatório para os médicos homeopatas? Comentários, se houver.

- fornecimento de medicamentos é satisfatório para os pacientes dos médicos homeopatas? Comentários, se houver.

- outros comentários que julgar de interesse em relação ao medicamento homeopático no serviço. 